DANMARKS GEOLOGISKE UNDERSØGELSE II. RK. NR. 109

Geological Survey of Denmark. II. Series. No. 109

\title{
Rhaetic to Lower Liassic palynology of the onshore south-eastern North Sea Basin
}

\author{
BY \\ Jens J. Lund \\ DANSK SAMMENDRAG \\ Rhat - nedre lias palynologi $i$ det sydostlige \\ Nordsø Bassins landområder
}

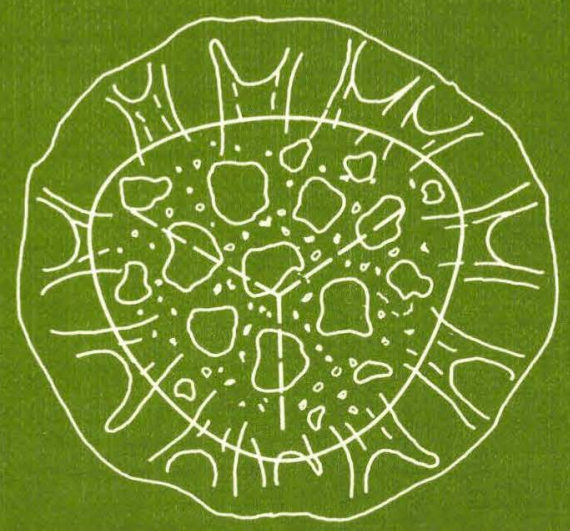

1 kommission hos C. A. Reitzels Forlag . København 1977 
Geological Survey of Denmark

II. Series. No. $109 \quad 1977$

ERRATA

p. 2, line 3-1000 eksemplarer - read: 1450 eksemplarer

p. 3, line 15 - Lias alfa 3 - beta - read: Lias alfa 3

p. 12, line 2-Will 1969 fig. 41 - read: Will 1969 p. 20 \& fig. 41

p. 12, line 14 - anhydrite, red clays and sand - read: anhydrite or sand, with red clays

p. 13, legend line 2 - with sand lams - read: sand/silt with clay lams

p. 16 , line $26 \& 27$, delete: (mainly only with the total range of the species

p. 16, line 29-TOTAL" - read: "total"

p. 30 , line $20 \& 21$ - compared to - read: and

p. 33, line 31 - p. 14, where - read: p. 14, when

p. 36 , line $38 \& 39$, delete: $\mathrm{S}$ spl. $7 \ldots \ldots \ldots$ Formation.

p. 47, line 1-Polypodiisporites - read: Conbaculatisporites

p. 56, line $5-11 / 58$ - read: $111 / 58$

p. 70 , line $25-x x$ - read: 25

p. 71 , line 29 - probably - read: regularly

p. 74 , line 10 - Surely two geni - read: Surely these two genera

p. 77 , line $31-s p .1$ (p.) - read: sp.

p. 82, line $9-(95)$ - read: (p. 80)

p. 99, line $39-259$ p. - read: pp. $259-288$

p. 100, add: Leschik, G. 1955: Die Keuperflora von Neuwelt bei Basel. II. Die Iso- und Mikrosporen. - Schweiz. paläont. Abh., 72, pp. 1-70.

p. 102, line 12 \& 13 - des Phytoplanktons - read: der Sporen und Pollen 
Danmarks Geologiske Undersøgelse. II. Række. Nr. 109

Geological Survey of Denmark. II. Series. No. 109

\section{Rhaetic to Lower Liassic palynology of the onshore south-eastern North Sea Basin}

By

Jens J. Lund

Dansk sammendrag:

Rhæt - nedre lias palynologi i det sydøstlige

Nordsø Bassins landområder

I kommission hos C. A. Reitzels Forlag København 1977 
D.G.U. II. rk. nr. 109

er sat med Fotosats Times

og trykt i offset i 1000 eksemplarer hos Andelsbogtrykkeriet i Odense.

Bogen er trykt på Thai-Cote, $115 \mathrm{~g}$ fra a/s De forenede Papirfabrikker.

ISBN 87-421-0704-0

ISSN 0366-9130

With 12 plates

Date of publication: 1977-03-31

The author's address:

Dr. rer. nat. J. Lund

Deutsche Texaco A.G.

D 3101 Wietze

B. R. Deutschland 


\section{Contents}

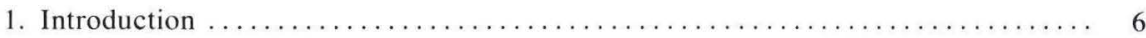

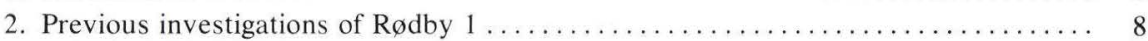

3. Stratigraphy of the NW German Basin $\ldots \ldots \ldots \ldots \ldots \ldots \ldots \ldots \ldots \ldots \ldots$

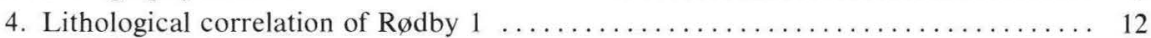

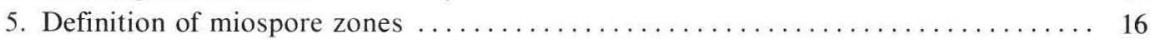

6. Palynostratigraphy in the Aller Area

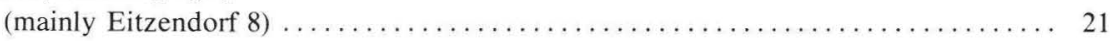

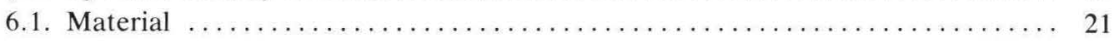

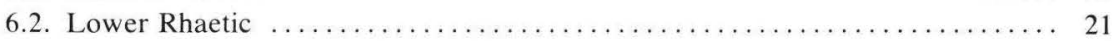

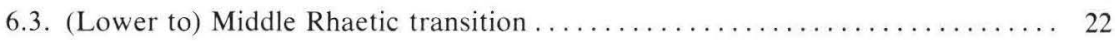

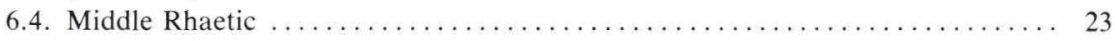

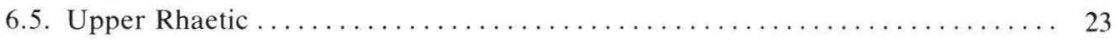

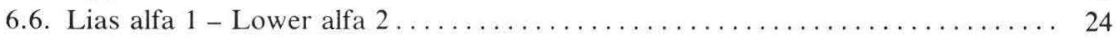

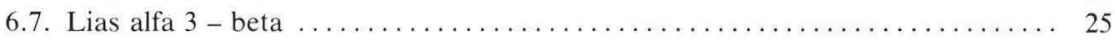

7. Palynology of the Pre-planorbis Beds to the Northwest $\ldots \ldots \ldots \ldots \ldots \ldots \ldots \ldots \ldots$

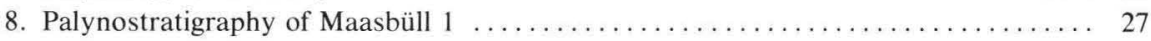

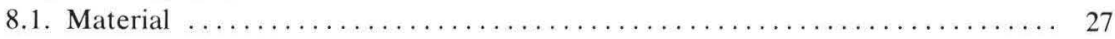

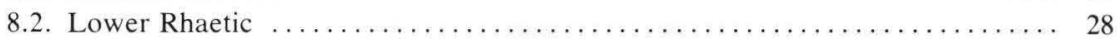

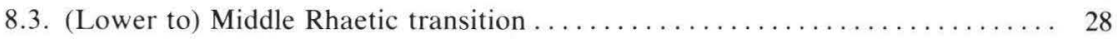

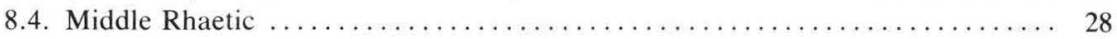

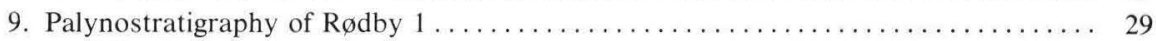

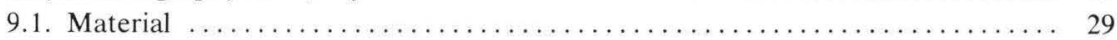

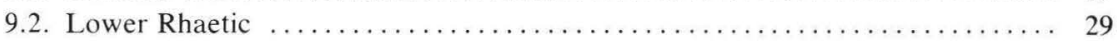

9.3. Middle Rhaetic $\ldots \ldots \ldots \ldots \ldots \ldots \ldots \ldots \ldots \ldots \ldots \ldots \ldots \ldots \ldots \ldots \ldots \ldots$

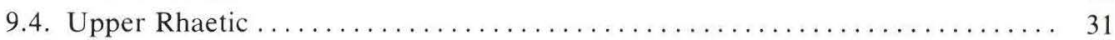

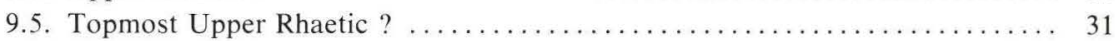

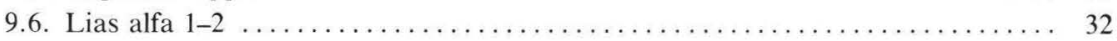

9.7. Lias alfa 3 (topmost alfa 2 not totally excluded) $\ldots \ldots \ldots \ldots \ldots \ldots \ldots \ldots$

9.8. Combined lithologic and palynologic correlation

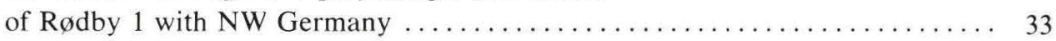

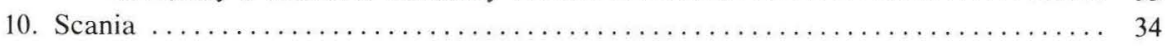

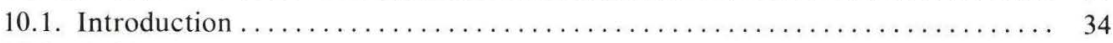

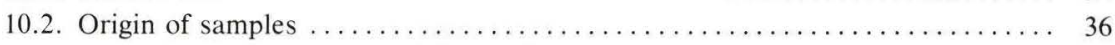

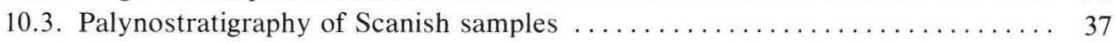

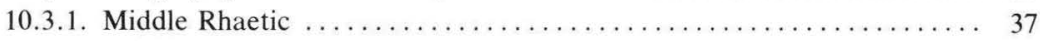

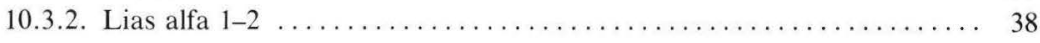

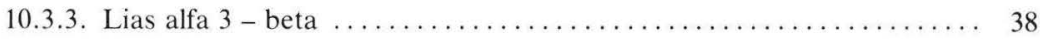

10.4. Correlation of macroflora- and microflora

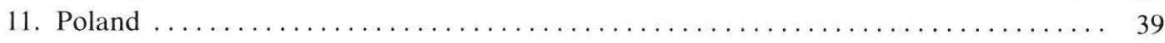




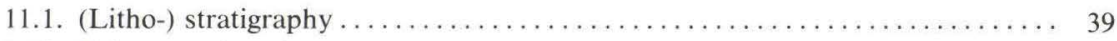

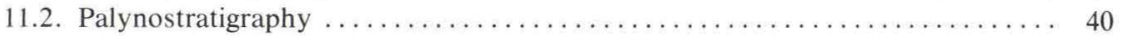

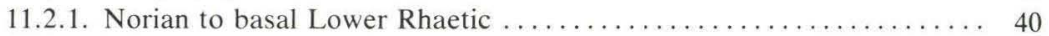

11.2.2. Topmost Lower Rhaetic . . . . . . . . . . . . . . . . . . . 41

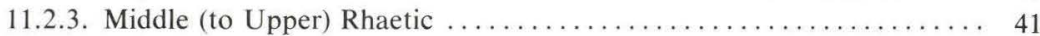

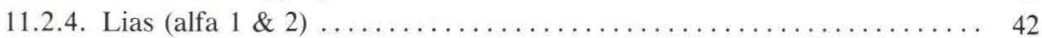

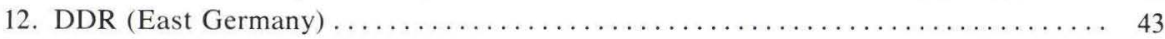

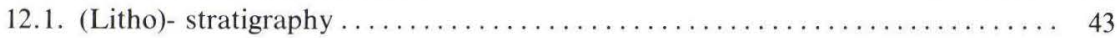

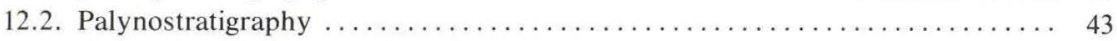

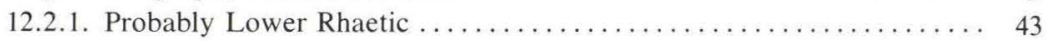

12.2.2. Middle Rhaetic ............................ 44

12.2.3. Upper Rhaetic . . . . . . . . . . . . . . . . . . . . . . . . . . . . . . 44

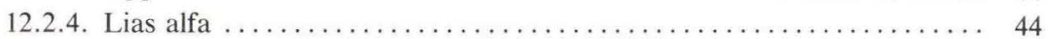

13. Age of the miospore zones and correlation of the Rhaetic

to Lower Liassic within the onshore south-eastern

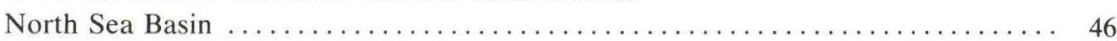

14. Palynological preparation $\ldots \ldots \ldots \ldots \ldots \ldots \ldots \ldots \ldots \ldots \ldots \ldots \ldots \ldots \ldots \ldots \ldots \ldots \ldots$

15. Key to the stratigraphic tables, photographic plates

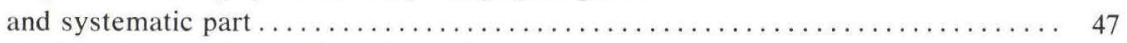

16. Explanations to the stratigraphic tables $\ldots \ldots \ldots \ldots \ldots \ldots \ldots \ldots \ldots \ldots \ldots \ldots \ldots \ldots$

17. Systematics, mainly based on the Rødby 1 material . . . . . . . . . . . . . . 49

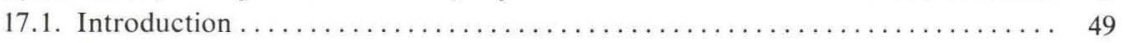

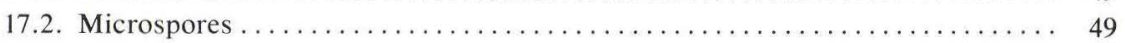

17.2.1. Trilete smooth microspores $\ldots \ldots \ldots \ldots \ldots \ldots \ldots \ldots \ldots \ldots \ldots \ldots \ldots . \ldots \ldots$

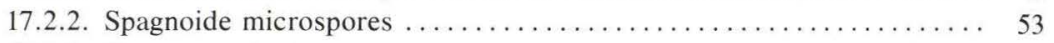

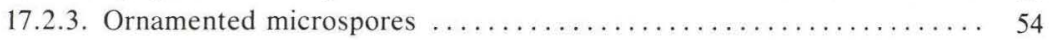

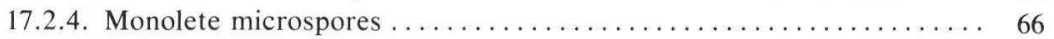

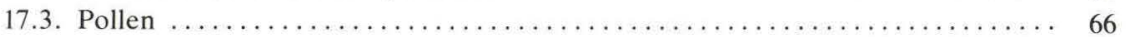

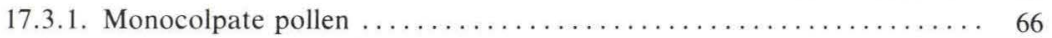

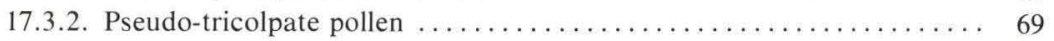

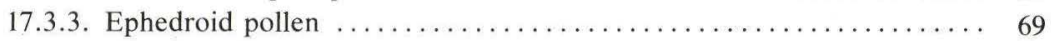

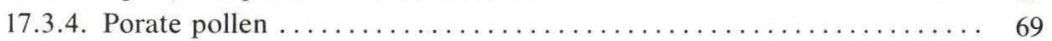

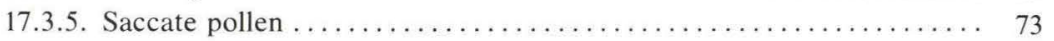

17.4. Aquatic palynomorphs $\ldots \ldots \ldots \ldots \ldots \ldots \ldots \ldots \ldots \ldots \ldots \ldots \ldots \ldots \ldots \ldots$

17.5. One probable mosspore from Eitzendorf $8 \ldots \ldots \ldots \ldots \ldots \ldots \ldots \ldots \ldots \ldots \ldots$

18. Appendix I: Depths of samples in Grevenhorst 1 and

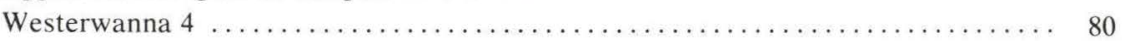

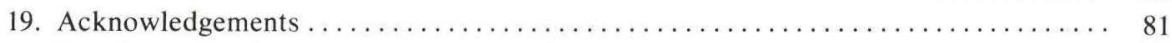

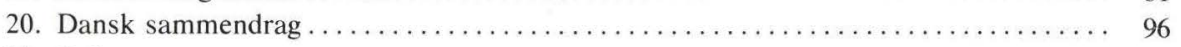

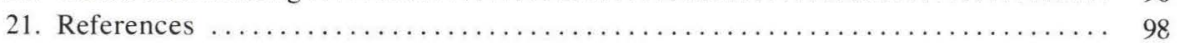




\section{Abstract}

Rhaetic to Lower Liassic microfloras of gymnospermpollen, microspores and aquatic palynomorphs from outcrops and cored wells in southern Scandinavia and NW Germany are investigated. 146 groups of palynomorphs, mainly species are presented from the Danish borehole Rødby 1. Based mostly on restudy of the holotypes 24 new combinations for species/varieties occurring in Rødby 1 are proposed. One new species, Corollina zwolinskai ranging from Lower to Middle Rhaetic is described.

The range of polynomorphs, mainly species are noted in the wells: Rødby 1, Maasbüll 1 and Eitzendorf 8 and in a composite section from Scania. The following miospore zones are defined: The Corollina Enzonalasporites Zone (? Norian - Lower Rhaetic), the Ricciisporites Conbaculatisporites Zone (transition (Lower -) Middle Rhaetic), the Rhaetipollis Limbosporites Zone (Middle Rhaetic), the Riciisporites Polypodiisporites Zone (Upper Rhaetic), the Pinuspollenites Trachysporites Zone (Lias alfa 1-2) and an unnamed zone with Cerebropollenites macroverrucosus (Lias alfa 3 to beta to ?, upper boundary not defined). Within the Corollina Enzonalasporites Zone the following subzones are defined: The Corollina Porcellispora Subzone, the Granuloperculatipolis Subzone and above the Enzonalasporites Conbaculatisporites Subzone. The two latter subzones are probably restricted to the Lower Rhaetic. The zones and subzones are used to correlate the mainly non marine deposits of Rødby 1 , Scania, Poland and E. Germany with the more marine deposits of NW Germanu.

In Scania the stratum typicum of the stratigraphically important species Limbosporites lundbladi Nilsson is shown to be (Middle) Rhaetic. Unmixed Lepidopteris and Thaumatopteris macrofloras are of (Middle) Rhaetic and Lias alfa age, respectively.

In E Germany the topmost "Middle Keuper" sensu Schulz is transferred to the Lower Rhaetic.

In Poland the Drawno Beds are shown to be Lower Rhaetic and the Weilichowo Beds to be Middle (to Upper) Rhaetic.

Rødby 1 is correlated lithostratigraphically with wells in NW Germany mainly on basis of the clay colours (red and green in the Lower Rhaetic, dark grey in the Middle Rhaetic, brown to light greenish grey in the Upper Rhaetic and dark grey in the basal Liassic). The lithostratigraphy agrees closely with the palynostratigraphy in Rødby 1. 


\section{Introduction}

More or less dark coloured plantbearing deposits are present over wide areas in Europe and North America at the Triassic-Jurassic boundary. These deposits rest on reddish Triassic "desert" deposits and are overlain by marine Liassic deposits.

The present investigation deals primarily with the pollen and microspores in the plantbearing deposits and the overlying Lower Liassic shales in the Danish borehole Rødby 1 (text fig. 1 \& 3). For biostratigraphic comparison the vertical distribution of pollen and microspores has been investigated in Scania and NW Germany (text fig. 1). In the latter area the Triassic section is developed in a more marine facies and can be better dated than in the Rødby 1 borehole and in Scania.

Based on the distribution of Norian/Lower Rhaetic to Lower Liassic microfloras observed in NW Germany, South Denmark and Scania and partly also known from literature on East Germany and Poland, a number of palynomorph zones are proposed. These zones are established to provide a biostratigraphical tool within the area mentioned (= south-eastern North Sea Basin). It is planned to correlate the Rhaetic Liassic to Lower Liassic microfloras of this area with East Greenland (in work) and the Alpine Area in forthcoming papers.

The literature on Rhaetic-Liassic palynology of Europe is extensive, and has been reviewed by E. Schulz (1967) and Orbell (1973). For the present investigation the papers of Nilsson (1958), Mädler (1964a), E. Schulz (1967) and Orlowska-Zwolinska (1966. 1967, etc.) are of special interest. It should be noticed that Nilsson (1958) did not only study the sapropel mentioned in the title of his paper, but also a number of the classical Rhaetic Liassic localities in Scania, partly reinvestigated here.

For convenience the terms Lower, Middle and Upper Rhaetic are used here in a traditional German/Danish sense (Schott 1943, Sorgenfrei \& Buch, 1964), and presented as follows: 


\begin{tabular}{lll}
\hline Present work & Schott 1943 & Will 1969 \\
\hline Upper Rhaetic & Oberrät & Triletes-Schichten \\
Middle Rhaetic & Mittelrät & Contorta-Schichten \\
Lower Rhaetic & Unterrät & Postera-Schichten \\
\hline
\end{tabular}

The term Rhaetic as used here does not necessarily equal the Rhaetian of the Alpine area. As supposed by Will (1969) and discussed on p. 11 the Lower Rhaetic sensu germanico may be placed in the Norian. However,

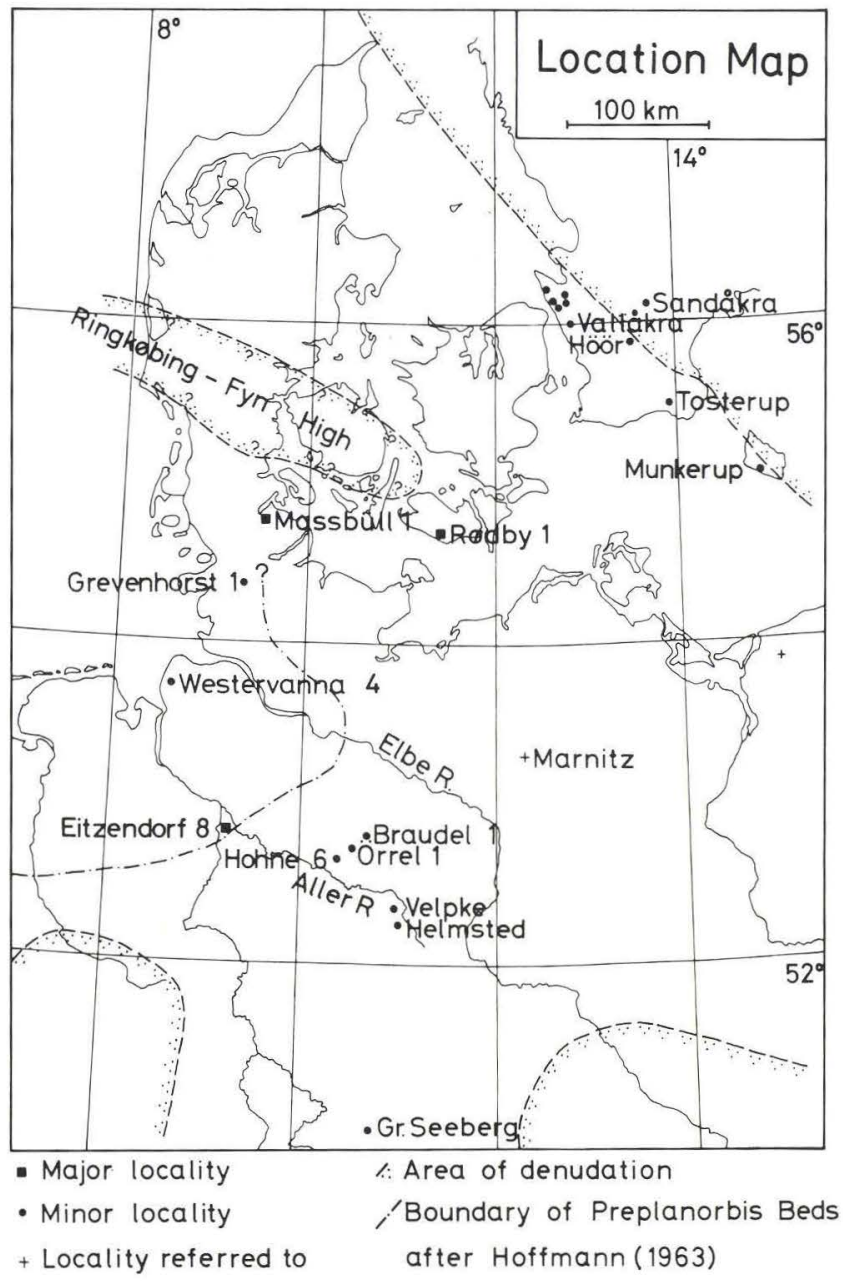

Text-fig. 1: Localities in Denmark, southern Sweden and northern Germany. 
this depends on where the Norian/Lower Rhaetic boundary is placed in the Alpine Area, a question which lays beyond the scope of this paper.

\section{Previous investigations of Rødby 1}

The Rhaetic-Liassic sediments in Rødby 1 can be briefly characterized as a mixed sequence of sand and clay layers, intercalated between Albian marls with belemnites and Keuper marls without sand. These Keupler marls contain anhydrite in their lower part indicating an arid climate. The change from Keuper marls without sand to Rhaetic deposits with sand is believed to reflect a change to a more humid climate, giving the rivers a greater transporting capacity in the Rhaetic (Larsen 1966).

Rødby 1 was drilled in 1952 and was completely cored in the Rhaetic and Liassic part.

Data on Rødby 1 were published by Sorgenfrei \& Buch (1964) who briefly summarized the lithology and the fossil content, mainly mollusks and foraminifera. Sorgenfrei \& Buch subdivided the section as follows:

Liassic: $1549^{\prime}-1837.5^{\prime}$ u.KB.

Rhaetic: $1837.5^{\prime}-2350^{\prime}$ u.KB.

In the Liassic the interval $1835^{\prime}-1837.5^{\prime}$ u.KB. was referred to the Preplanorbis Zone, $1824^{\prime}-1826.5^{\prime}$ u.KB. to Lias alfa (due to presence of the index ammonite Psiloceras planorbis) and 1798'-1807' u.KB. to Lias gamma. As referred to below (p. 9) Bertelsen and Michelsen (1970) showed that the Liassic of Rødby 1 all belonged to Lias alfa. The Rhaetic was divided by Sorgenfrei \& Buch into an upper predominantly sandy part (above 2260' u.KB.) and a lower predominantly clayey part with ostracodes. Note that the depths here given are depths under Kelly Bushing (u.KB.) and not below ground as in Sorgenfrei \& Buch 1964. The Kelly Bushing was placed 11' above ground and 18' above sea level.

Detailed lithological data on Rødby 1 were published by Larsen (1966, pl. 15) who focused on the content of heavy minerals but also used Schlumberger logs, colours, content of carbonate etc. On the basic of the content of heavy minerals he considered the Rhaetic Liassic of Rødby 1 to consist of redeposited sediments, different from those of the deltas along the Scandinavian Shield in the northeastern part of Denmark. Therefore, he did consider the Rhaetic and Liassic sediments of Rødby 1 to be derived from the Ringkøbing-Fyn High. The assumption of such a "local" origin is supported by the distribution of deltaic sand lenses in the Northern DDR, indicating transport from the northwest in the Rhaetic (Rusitzsca 1967). At the top of the Liassic section a one meter thick weathered horizon was found (Larsen 1966). 
The Rhaetic Liassic megaspores and ostracodes were studied by Bertelsen and Michelsen respectively (Bertelsen \& Michelsen 1970). The last mentioned author also critically discussed the macrofossil fauna used by Sorgenfrei and Buch to correlate the Liassic of Rødby 1. Bertelsen and Michelsen concluded that all of the Liassic should be referred to as Lias alfa, and that the Rhaetic Liassic boundary should be moved down to $1858^{\prime}$ u.KB. placing the interval $1835^{\prime}-1858^{\prime}$ in the Liassic pre-planorbis zone. The megaspores in the Liassic comprised the Nathorstisporites hopliticus community while the Triletes pinguis community was found in the Rhaetic. In the pre-planorbis zone a mixed assemblage was found, dominated by specimens from the $N$. hoploticus community (Bertelsen in Bertelsen \& Michelsen 1970).

Later Michelsen compared the Liassic lithology and microfauna of Rødby 1 with entirely marine wells north of the Ringkøbing-Fyn High. He concluded that in Rødby 1 the interval $1839^{\prime}-1753^{\prime}$ u.KB. was fully marine, that of $1753^{\prime}-1650^{\prime}$ u.KB. was deposited under marine conditions interrupted by delta-like deposition, and that $1650^{\prime}-1549^{\prime}$ u.KB. was marine but with an increasing terrestrial influence towards the top (Michelsen 1973).

\section{Stratigraphy of the NW German Basin}

The following review of the Rhaetic to Lower Liassic stratigraphy of the NW German Basin is based on the literature.

The purpose is to provide a foundation for the lithostratigraphical correlation with Rødby 1 in passage 4. and for the dating of the material treated palynologically in passage 6 . to 9 .

A standard lithostratigraphy for the NW German Basins was erected by Schott (1943) on the basis of 9 wells of which the northernmost was situated at Lübeck, about $100 \mathrm{~km} \mathrm{SSW}$ of Rødby.

The standard lithostratigraphy of Schott is shown on text fig. 2. The colours of the clays are of prime importance in this lithostratigraphy. Dark grey clay colours distinguish the Middle Rhaetic from the underlying strata ("Unterrät \& Mittleren Keuper" sensu Schott) where green and reddish clay colours predominate. The clay colours of the Liassic equal those of the Middle Rhaetic in being dark grey. However, the interjacent Upper Rhaetic differs by lighter greenish and brownish clay colours. The presence of these lighter clay colours in the Upper Rhaetic makes it very easy to distinguish the Liassic, the Upper Rhaetic and the Middle Rhaetic lithostratigraphically.

Sand is of less importance than the clay colours in the lithostratigraphy of 


\begin{tabular}{|c|c|c|c|c|c|c|c|}
\hline 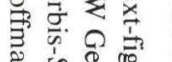 & & $\mathrm{SCl}$ & НОTT 1942 & & WILL 15 & $9(1953)$ & \\
\hline 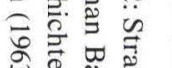 & LITHOLO & GY & STRATIGRAPH & & STRATIGRAPHY & & \\
\hline & Clay Colours & & & & & & \\
\hline 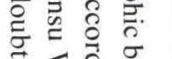 & dark grey & & Psilonotenschichten & Lias & Psilonoten - Schichten & Unterer & Lias \\
\hline 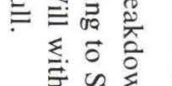 & greenish - & I $^{-}:$ & $\begin{array}{l}\text { oberer } \\
\text { Oberrätschiefer }\end{array}$ & & Präplanorbis-Schichten & Lias & \\
\hline ₹ & grey & $\because \cdots:$ & Oberrätsandstein & Oberrät & & & \\
\hline & brown at base & $-{ }_{-}^{-}$ & $\begin{array}{l}\text { unterer } \\
\text { Oberrätschiefer }\end{array}$ & & Triletes-Schichten & & \\
\hline 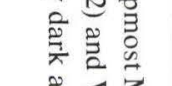 & & $-{ }_{-}^{-}-:$ & $\begin{array}{l}\text { oberer } \\
\text { Mittelrätschiefer }\end{array}$ & & & Rhätkeuper & Rhät \\
\hline & dark grey & & Mittelrätsandstein & Mittelrät & Contorta-Schichten & & \\
\hline 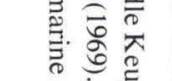 & & $-_{-}^{-}-:$ & $\begin{array}{l}\text { unterer } \\
\text { Mittelrätschiefer }\end{array}$ & & & & \\
\hline 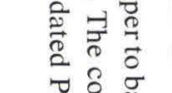 & $\begin{array}{l}\text { brown \& } \\
\text { green }\end{array}$ & $\begin{array}{l}\text { - } \\
-\end{array}$ & & Unterrät & Postera-Schichten & Steinmergel- & \\
\hline 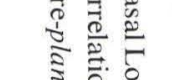 & $\begin{array}{l}\text { red \& } \\
\text { green }\end{array}$ & ${ }_{-}^{-}{ }_{-}^{-}$ & Steinmergelkeuper & mittleren & Saurichthys-Schichten & keuper & Nor \\
\hline 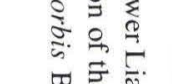 & & & & Keuper & Oberer Gipskeuper & $\begin{array}{l}\text { Mittlerer } \\
\text { Keuper }\end{array}$ & \\
\hline 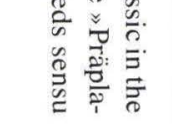 & Legend: $\therefore$ & Sand 1 & one) $\quad-$ Clay (stone) & I calca & I dolomitic & & \\
\hline
\end{tabular}


Schott (1943), but is used to distinguish Lower Rhaetic from Middle Keuper as it is also used in Denmark Sorgenfrei \& Buch 1964. Furthermore, both the Middle Rhaetic and the Upper Rhaetic are divided in three by a maximum of sand in the middle part of each. The magnitude of sand development, however, varies from area to area, and the sand in the Middle Rhaetic ("Mittelrätsandstein" sensu Schott) may even be absent. Hence the content of sand is a less reliable lithostratigraphical character than the colours of the clay. The probable causes of clay coloration are discussed on page 12 .

The geophysical, lithological and paleontological characteristics of the NW German Rhaetic Basin were described by Will (1969, thesis from 1953), who used the same lithologically determined boundaries as Schott. However, he applied new terms to the stratigraphic units, based on the content of fossils (Will 1969 fig. 40 \& 41, text fig. 2 here). Will showed that Schotts "Mittelrätschiefer' contained a Rhaetian fauna with the lamellibranch Pteria contorta, while Schotts ' Unterrätschiefer' contained a different, probably less marine influenced fauna with the lamellibranch Anodontophora postera and a rich variation of ostracodes. This fauna, the postera fauna, contained no alpine index fossils, but since it showed similarity to the Lower Keuper fauna (Will 1969, p. 127), it was considered by Will to be of Norian age. This dating was later accepted by Kozur \& Mostler (1972), although neither of these authors were able to prove the correlation with the Alpine area. According to Urlicks (1972) one of the ostracode species (Lutkevichinella (al Limnocythere) keuperiana), which is restricted to the Postera-Schichten in Northwest Germany, is present in the Norian of the Alpine area, whereas it is absent in the Rhaetian. This supports a Norian age of the PosteraSchichten. However, as the Upper Norian in the Alpïne Area contains Rhaetvicula contorta and possibly has to be joined with the Rhaetic (compare Urlichs 1972 and Wiedmann 1972) the Postera-Schichten are tentatively referred to as Lower Rhaetic here.

Schott's clay colour stratigraphy was supported by Will, applying it to a number of new wells. Through this the picture grew more detailed, as it turned out that there also existed intercalations of dark grey clay in the greenish Postera-Schichten especially in the northern part of the NW German Basin. However, the topmost part of the Postera-Schichten was generally marked by greenish clay colours. These greenish clays known as "Grüne Krumbecksche Lagen'” in Germany equalled the Tea Green Marls in Great Britain lithographically (Will 1969, p. 145-146, fig. 45-46).

Will also investigated the megaspores and found that the pinguis assemblage appeared in the Postera-Schichten and reached its greatest diversification in Triletes-Schichten. The pinguis assemblage was also present in Pre- 
planorbis Beds but was missing in the overlaying level, in which Nathorstisporites hopliticus was found (Will 1969 fig. 41).

Will (1969, p. 118-119) stressed the close connection between the clay colours and the content of fossils demonstrated by the sequence: varigated and greenish clays with Anodontophora postera, dark-grey clays with $P$. contorta superimposed by brownish and light green clays without fauna. This connection could be followed from Schleswig-Holstein to Switzerland and from the Netherlands to Franken. Even to Sweden, Great Britain and France some elements of this sequence could be traced. Will discussed the causes to the lithostratigraphical usable criteria and attributed them mainly to a climatic change from an arid to a humid climate. The changes were demonstrated by the sequence from Oberer Gipskeuper (arid: gypsum/ anhydrite and lateritic dust) via Saurichtys-Schichten (semiarid: no gypsum/ anhydrite, red clays and sand) and Postera-Schichten (subtropical climate with annual variations: wood with annual rings, greenish to dark grey clays, dissolved silicic acid) to Contorta-Schichten (full humid tropical climate: wood without annular rings, dark clays, kaolonite and silica cemented sandstones). For the Triletes-Schichten with the lighter clay colours Will mentioned the possibility of a more subtropical climate, but he did also stress their non-marine character in opposition to the marine ContortaSchichten. Here the dark clay colours were partly ascribed to organic production from microplancton (Will 1969, p. 157-176).

It should be noticed that the clay colour stratigraphy and Will's paleontological correlations are based on empirical data. Their validity is independent to whether or not the above referred explanations to the lithostratigraphically usable criteria are correct or not.

\section{Lithological correlation of Rødby 1}

On the basis of the literature referred to in passage 2.2. and the present author's experience of reading core descriptions from 9 NW German wells, a lithological correlation of Rødby 1 with the NW German Basin is attempted below. Not all stratigraphic levels of the mentioned wells or in Rødby 1 can be correlated on lithology but the amount of levels which cannot be correlated does not seem higher in Rødby 1 than in an average boring in the NW German Basin.

The data of Rødby 1 on which the correlation is based are mainly shown in textfig. 3 which is drawn from the original descriptions. Further data on content of carbonates etc. are given by Larsen (1966, pl. 15).

On text fig. 3 oxidation time (min. in Schulze) for palynological prepara- 


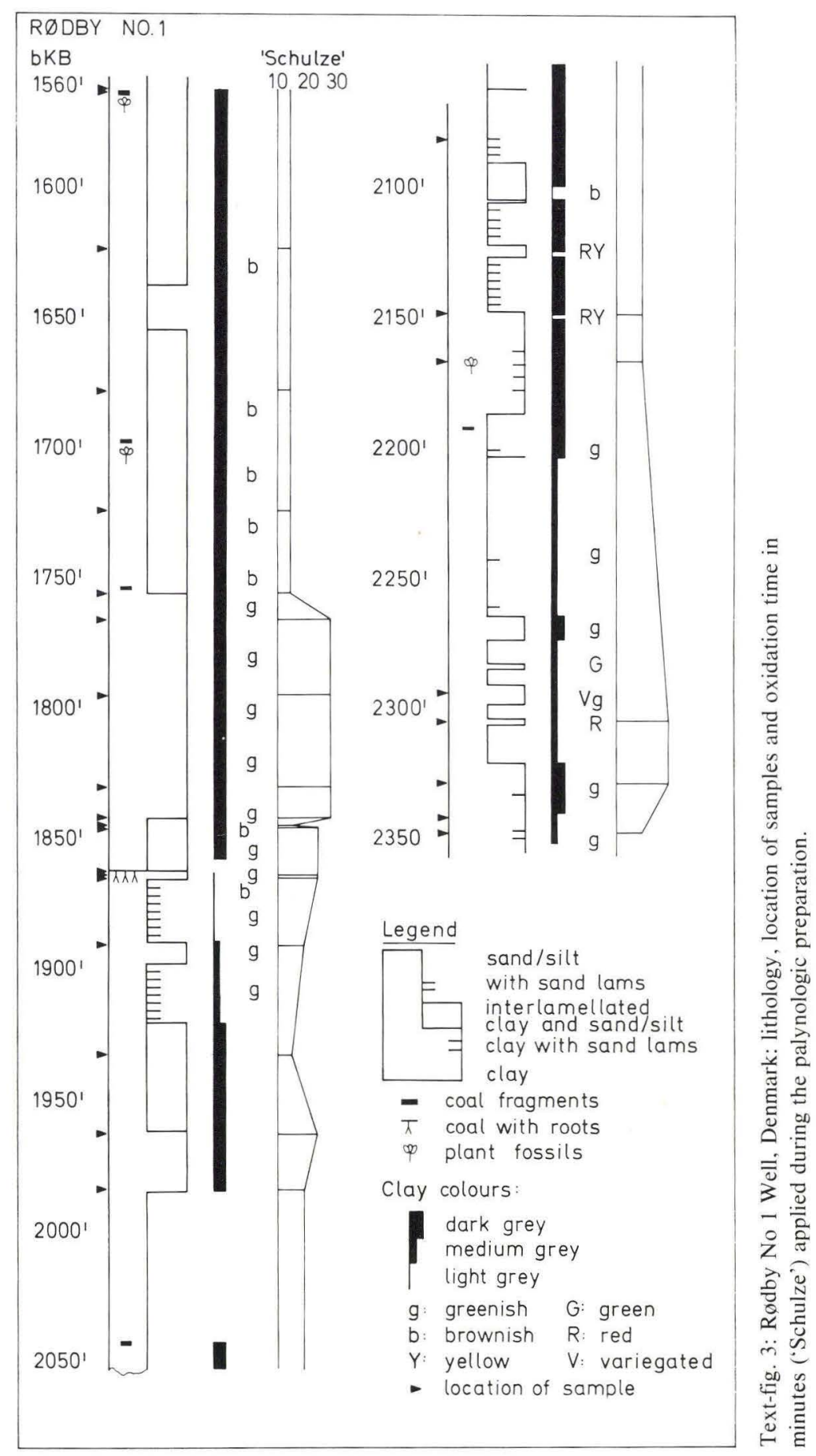

D.G.U. II. rk. nr. 109 
tion is shown. This preparation technique is described in passage 14. Remarkable is the change of time occurring about $1760^{\prime}$ in Rødby 1 . A similar change was observed at the Lias alfa 1 to 2 junction in Eitzendorf 8. This change is therefore considered to be a usable lithostratigraphical criterion.

Lithologic correlation between Rødby 1 and the NW German Basin:

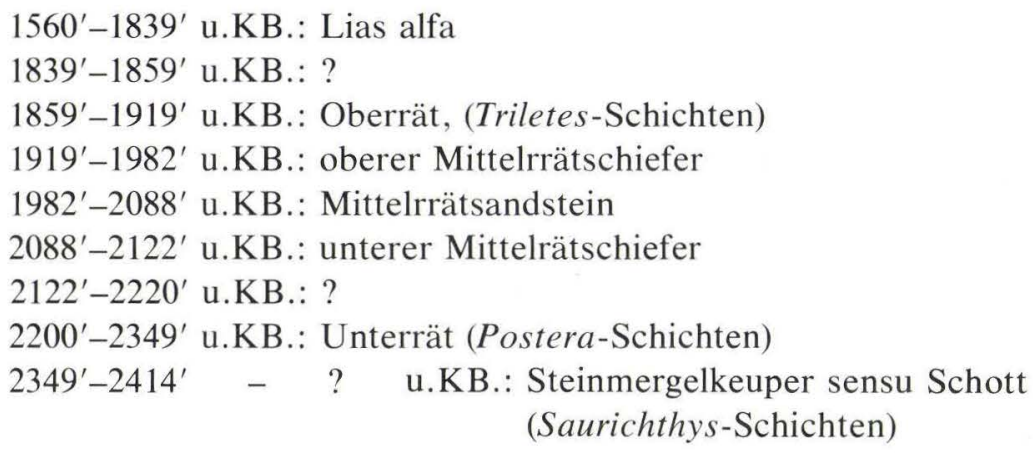

The sections $1839^{\prime}-1859^{\prime}$ and $2122^{\prime}-2200^{\prime}$ are problematic and therefore not correlated lithostratigraphically. They are discussed in some detail below.

The brownish clay interval $1839^{\prime}-1859^{\prime}$ differs from the light greenish grey upper part of the Triletes-Schichten and also from the dark grey Preplanorbis Beds and Planorbis Beds. Brownish clays are not reported on this level neither by Schott (1942) nor by Will (1969). It is therefore not possible to correlate this unit with the standard lithostratigraphic column of the NW German Basin. However, it is noticeable that brownish clay occurs at a slightly deeper level between the upper light greenish part of the TriletesSchichten and the underlying dark grey Contorta-Schichten. Probably the brownish clay represents a transitional facies between the dark grey clay and the light greenish clay. Presence of brownish clay above the light greenish clay of the topmost Triletes-Schichten in Rødby 1 then suggests that the change in facies was more gradual there than normal in the NW German Basin.

The deeper interval $2122^{\prime}-2200^{\prime}$ contains in the upper half two thin red yellow variegated clay layers. Since the superimoised clays are dark grey and not green, the succession of clay colours in Rødby 1 differs from that of the NW German Basin. Two explanations are offered.

1: These red clays result from local redeposition of red clay and are of no lithostratigraphical importance, or 
2: Red clays occur at basin marginal locations (Rødby in the north, Gross Seeberg in the south (Seidel 1965)) at the top of the Postera-Schichten, whereas green clays occur in the central parts of the basin. The content of palynomorphs shows (see passage 9.3.) that this section equals the Contorta-Schichten. Therefore the first explanation mentioned is the only usable when a chronostratigraphical correlation is attempted. 


\section{Definition of miospore zones}

Based upon literature and the present investigations material from NW Germany, Rødby 1 and Scania a number of miospore zones for the onshore south-eastern North Sea Basin are defined below. Brief statements on the palynostratigraphy of the investigated material were published by Lund (1975 \& 1976), however, no zones were proposed.

The succession of diagnostic miospores and some accessory palynomorphs are shown on text-fig. 4. The vertical distribution of all palynomorphs are given separately for Eitzendorf 8, Maasbüll 1, Rødby 1 and Scania in Tables I-IV.

The purpose of establishing these zones is to make clear the main features of vertical variation of miospores (= pollen and microspores) in the rich Rhaetic Liassic microfloras of the southeastern North Sea Basin. To make the zonation practical most of the zones are defined by the regular presence or absence of single species or genera. However, these zones should not be considered (concurrent) range-zones, interval-zones etc. because these genera/species probably will be found sporadically on levels where they are now unknown. The zones should be considered to be more or less local assemblage-zones defined by the acme of selected species or genera. An equal kind of zone was used by Orbell (1973).

It should be noticed that the climate varied from arid to humid and the environment of deposition from limnic to marine from the Norian to the Lower Liassic in the area probably with a maximum of humidity in the Middle Rhaetic (Will 1969). Much of the variations observed in the microfloras are ascribed to these fluctuations. Some of the ranges observed may coincide with the total range of the species (mainly only with the total range of the species (mainly only with lower or upper boundaries). However, published data on the microfloras north of the investigated area are so scarce that not even the TOTAL" range of the species in Europe are known sufficiently.

\section{The Corollina Enzonalasporites Zone}

Defined by the contemporary presence of Corollina (=Classopollis) and Enzonalasporites. Corollina is very common and comprises both varieties 


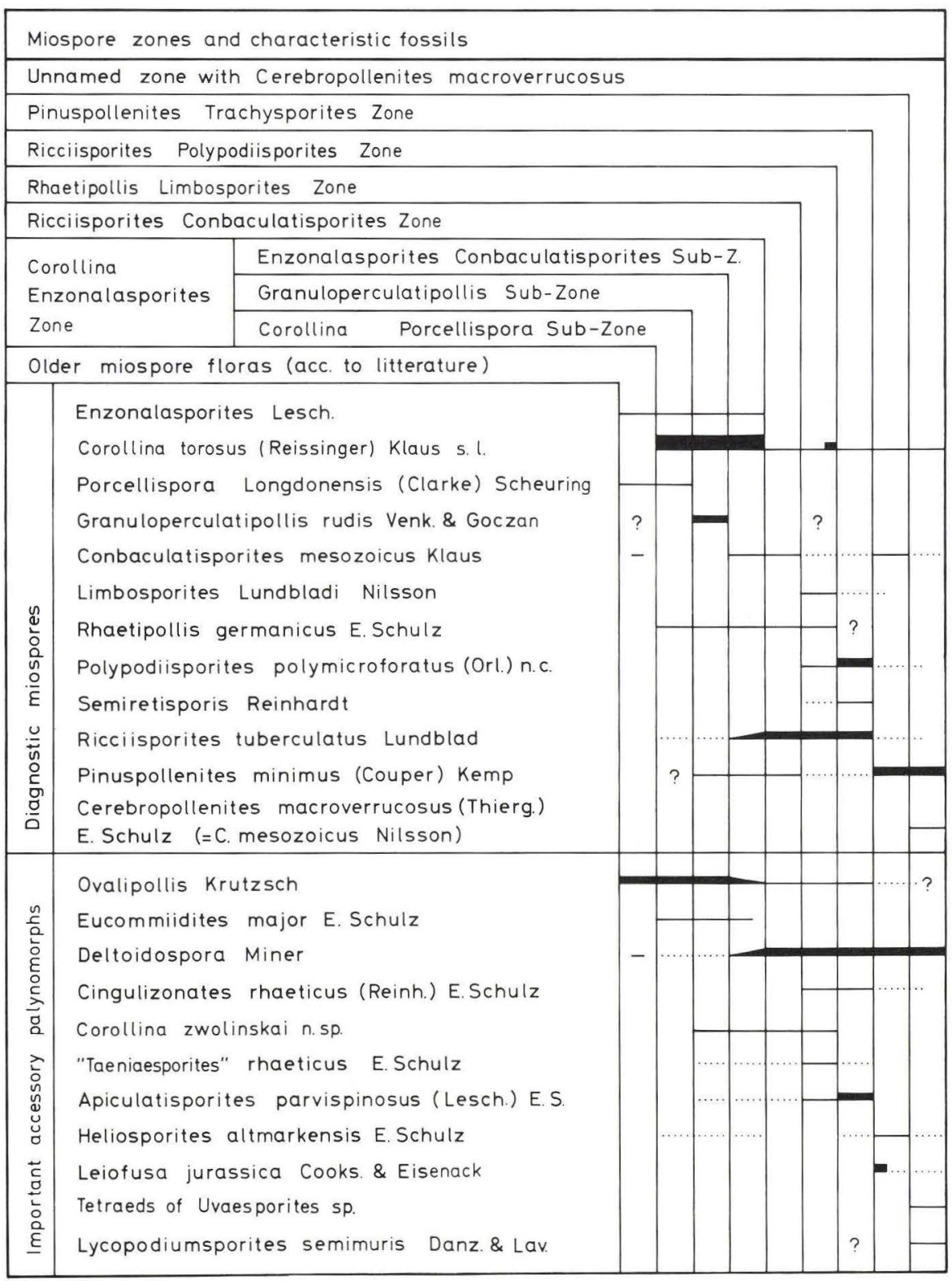

Text-fig. 4: Diagnostic miospores and important accessory palynomorphs of the Rhaetic to Lower Liassic miospore zones of the south-eastern onshore North Sea Basin. 
with and without circumequatorial striations. Eucommiidites major E. Schulz occurs regularly but in low number and is characteristic of this zone in the NW German Basin. Ovalipollis is always present and occurs in larger numbers than Ricciisporites which is normally rare, especially in the two lower subzones, where also triangular smooth microspores are rare. The ornamented microspores include older types like Porcellispora longdonensis (Clarke) Scheuring and younger "Liassic" types like Heliosporites altmarkensis E. Schulz, while "Rhaetic" types like Limbosporites lundbladi Nilsson are missing.

\section{The Corrollina Porcellispora Subzone}

The lower subzone in the Corollina Enzonalasporites Zone is defined by the contemporary presence of Corollina (common) and Porcellispora longdonensis (Clarke) Scheuring (common among the trilete ornamented microspores).

This subzone is only represented by one sample in the investigated material (Rødby 1: 2349' u.KB.), but similar microfloras are known from the literature (Orlowska-Zwolinska 1967). In the mentioned sample Ovalipollis notabilis Scheuring (common among the saccate pollen) is a characteristic element together with rare Echinitosporites eliacoides E. Schulz and Heliosporites altmarkensis E. Schulz.

\section{The Granuloperculatipollis Subzone}

The middle subzone of the Corollina Enzonalasporites Zone is defined by the regular presence of Granuloperculatipollis rudis Venkatachala \& Goczan. The delimination of this subzone to the subzone above is somewhat doubtful, as $G$. rudis is although rarely, present higher in the sequence.

\section{The Enzonalasporites Conbaculatisporites Subzone}

The topmost subzone in the Corollina Enzonalasporites Zone is defined by the contemporary presence of Enzonalasporites and Conbaculatisporites mesozoicus Klaus. As the latter mentioned species are also present in older deposits outside the area under investigation (Carnian Austria original description by Klaus 1960), this subzone is a local one.

\section{The Ricciisporites Conbaculatisporites Zone}

This zone is mainly characterized by the absence of both older types like Enzonalasporites and younger types like Limbosporites lundbladi Nilsson. Conbaculatisporites/Trachysporites are common as in the underlying subzone, and Ricciisporites are mostly common as in the superimposed zone. 
Defined by the contemporary presence of Rhaetipollis germanicus E. Schulz and Limbosporites lundbladi Nilsson.

The most impressive feature of the microfloras in the Rhaetipollis Limbosporites Zone is the apparent abundance of Ricciisporites tuberculatus Lundblad, which more or less dominates the visual impression obtained by low magnifications due to its relatively large size and darker colour, although the content of Ricciisporites tuberculatus rarely exceeds 10 per cent.

\section{The Ricciisporites Polypodiisporites Zone}

This Zone is characterized by the common presence of Polypodiisporites polymicroforatus (Orlowska-Zwolinska) n. comb. (= Convolutispora microrugulata E. Schulz) or of Semiretisporis together with a rich variation of other mostly trilete microspore species.

The Ricciisporites Polypodiisporites Zone is defined from the underlying Rhaetipollis Limbosporites Zone by the practical absence of Rhaetipollis germanicus E. Schulz. Ricciisporites tuberculatus is normally less common than in the underlying zone but more common than in the superimposed Pinuspollenites Trachysporites Zone.

The Pinuspollenites Trachysporites Zone

Defined by the common presence of Pinuspollenites minimus (Couper) Kemp and the absence of Cerebropollenites macroverrucosus (Thiergart) E. Schulz. The group of trilete ornamented microspores is dominated by "Liassic" types as Conbaculatisporites/Trachysporites (C. mesozoicus Klaus, T. tuberosus Nilsson etc.) and Uvaesporites reissingeri (Reinh.) $\mathrm{n}$. comb. etc. while "Rhaetic" types as Densosporites fissus (Reinh.) E. Schulz and Limbosporites lundbladi Nilsson etc. are missing or sporadically present. Heliosporites altmarkensis E. Schulz is common in the NW German Basin including Rødby 1, but absent in Scania where on the other hand Lycopodiumsporites austroclavatidites (Cooks.) Pot. is common.

The basal part of this zone is characterized by an acme of Leiofusa jurassica Cookson \& Eisenack in the NW German Basin including Rødby 1.

Unnamed zone with Cerebropollenites macroverrucosus

Only the lower part of the zone is investigated here. It is defined from the underlying zone presence of Cerebropollenites macroverrucosus (Thiergart) E. Schulz ( $=C$. mesozoicus (Couper) Nilsson). The upper limit of this unnamed zone is not fixed here, it could be defined by the incoming of Callialasporites. 
A few Rhaetic species like Ricciisporites tuberculatus Lundblad are still sporadically present in the basal part of this zone. Lycopodiumsporites (inclusive of L. semimuris Danze-Corsin \& Laveine) are fairly common and tetrads of Uvaesporites sp. are worth noticing. 


\section{Palynostratigraphy of the Aller Area (mainly Eitzendorf 8)}

\subsection{Material}

The investigation of the southern part of the NW German Basin is concentrated on the borehole Eitzendorf 8, because it represents a maximum of marine influence, and the whole section of interest (Lower Rhaetic to Lias beta) is developed and well represented by cored intervals. The palynomorph content of the more than $200 \mathrm{~m}$ thick section is shown on table 1. Palynomorphs from other investigated localities in the Aller Area examined by this provisional work are only mentioned in the text, when emphasis is placed on special topics like the dependence of the microfloras on depositional envirnonment etc.

Eitzendorf 8, referred to below as E8, was drilled in 1949 for Deutsche Erdöl AG and was studied by Hecht, Hoffmann and Rühl. Hecht investigated the microfossils, which later have been reinvestigated by Plumhoff. These picks are referred to as "new microfauna datings"' below.

The Liassic section of Eitzendorf 8 was partly cored and the Upper Triassic section including the Rhaetic was completely cored. The boring terminated in varigated dolomitic marls (Saurichtys-Schichten sensu Will) and did not reach the Keuper evaporites.

\subsection{Lower Rhaetic}

In Eitzendorf 8 the boundary between Mittel Keuper and "Unter Rhät" originally was placed just below spl. $1180 \mathrm{~m}$ (table 1) indicated by a change from dark bluish grey clay to greenish marls (below). Reddish partly dolomitic marls were present from just below spl. $1199 \mathrm{~m}$.

A comparison with the lithostratigraphy according to Will (1969) reveals the mentioned top of the "Mittel Keuper" as probably equivalent to the "Grüne Krumbeck'sche Lagen" i.e. the top of the Postera-Schichten. The lower partly reddish section would then correspond to the lower part of the Postera-Schichten i.e. the Prima Zone. This fits partly with the "new microfossil datings" as the lower reddish part is dated as "ko alfa unten", whereas the upper greenish part together with the superjacent blueish grey clays up to spl. $1173 \mathrm{~m}$ were named "ko alfa". The microfauna, mainly 
ostracodes, cross this lithologic boundary between the greenish and dark grey clay. Two explanations are possible, either the Postera-Schichten in Eitzendorf 8 include some dark grey clay, or the postera microfauna survives in the Middle Rhaetic. The microflora of pollen and microspores also crosses this lithologic boundary, and for that reason, the former explanation is accepted here.

E 8 spl. 1205-1180 m: The Corollina Enzonalasporites Zone. The lithology and microfauna are discussed above. The contemporary presence of Corollina torosus (Reissinger) Klaus (= Classopollis classoides Pflug) and Enzonalasporites and Eucommiidites major E. Schulz cause the assignment of this section to the Corollina Enzonalasporites Zone.

E 8 spl. 1205-1199 m: The Granuloperculatipollis Subzone. Besides the regular presence of Granulopercularipollis rudis Venk. \& Gocz. this subzone is also characterized by the trilete ornamented microspores including several species of Anapiculatisporites (A. telephorus (Pautsch) Klaus \& A. spiniger (Lesch.) Reinh.) which are regularly present. Ovalipollis (O. ovalis Krutsch \& $O$. breviformis Krutsch) are considerably more common than Ricciisporites (E 8 spl. 1205 m: 32 Ov./0 Ric., 1203 m: 72 Ov./11 Ric., 1199 m: 24 Ov./0 Ric.)

E 8 spl. 1180-1173 m: Enzonalasporites Conbaculatisporites Subzone.

Characterized by the contemporary presence of Enzonalasporites and Conbaculatisporites mesozoicus Klaus and by the absence of Granuloperculatipollis rudis Venk. \& Gocz. As in the underlying subzone and sample $1192 \mathrm{~m}$, which is not referred to any subzone, Ovalipollis is considerably more common than Ricciisporites (E 8 spl. 1192 m: 23 Ov./3 Ric., 1180 m: 44 Ov./5 Ric., 1173 m: 30 Ov./1 Ric.).

\section{3. (Lower to) Middle Rhaetic transition}

E 8 spl. 1167-1159 m: The Ricciisporites Trachysporites Zone.

This section consists of dark clay with subordinate sand intercalations. According to core descriptions this section comprises partly "Unterrhät" with dark blueish grey clay (spl. 1167-1164 m and the base of "Mittelrhät" with faintly blueish darkgrey pyritic clay (spl. $1157 \mathrm{~m}$ ). According to the "new microfauna datings" sample $1167 \mathrm{~m}$ was dated to "ko beta unten alfa" and sample 1157 to "ko beta". Hence this section encompasses a part of the Middle Rhaetic and possibly also some Lower Rhaetic, when dated by lithology and microfauna. 
The section is characterized by the absence of both diagnostic Lower Rhaetic and Middle Rhaetic elements like Enzonalasporites and Limbosporites, respectively. Trachysporites/Conbaculatisporites, as in the underlying subzone, are common among the trilete ornamented microspores. Ricciisporites may be more common than Ovalipollis (spl. $1167 \mathrm{~m}: 18$ Ov./ 7 Ric., 1164 m: 5 Ov./ 13 Ric., 1157 m: 32 Ov./ 32 Ric.).

\subsection{Middle Rhaetic}

E 8 spl. 1149-1128 m: The Rhaetipollis Limbosporites Zone.

This section consists of dark blueish grey clay with subordinate sand intercalations, except for the top where intercalations of redbrown clay are present (? Argiles rouge de Levalloids, see Will 1969). The section contains the lamellibranch Taeniodon and a Middle Rhaetic microfauna.

It is characterized by a palynomorph assemblage with numerous Ricciisporites, common Rhaetipollis germanicus $\mathrm{E}$. Schulz and regular presence of Limbosporites lundbladi Nilsson, Cingulizonates rhaeticus (Reinh.) E. Schulz and thick walled Araucariacidites. (spl. 1149 m: 7 Ov/ 33 Ric., 1142 m: 9 Ov./ 10 Ric., 1128 m: Ov./ Ric.). Stratigraphically higher, between the Middle and Upper Rhaetic, a number of species disappear: Rhaetipollis germanicus E. Schulz, "Vesicaspora" fuscus (Pautsch) Morbey, Corollina zwolinskai n. sp. Granuloperculatipollis rudis Venk. \& Gocz. etc. At a similar level in the Rødby 1 borehole (between R 1930' and R 1888') a number of species, partly other than in Eitzendorf 8 also disappear. These levels probably represent the same microfloral change (thinning of Middle Rhaetic microflora) and the difference in species noted to disappear possibly reflects variance in the length of investigation (many more specimens observed per sample in Rødby 1 than in Eitzendorf 8).

\subsection{Upper Rhaetic}

E 8 spl. 1122-1103 m: The Ricciisporites Polypodiisporites Zone.

The lower part of this section with spl. $1122 \mathrm{~m}$ consists of medium grey chalky clay with thin sand layers and corresponds to "unterer Oberrätschiefer' sensu Schott (1943, and textfig. 2 here). These beds are overlain by a fine grained sandstone (Triletes Sandstein sensu Will) with a few thin greenish medium grey chalky claylayers (spl. $1110 \mathrm{~m}$ ) superimposed by a greenish medium grey clayball conglomerate with chalky cement (spl. 1103 m, "Schottsche konglomerate" (Will 1969 p. 143)).

Palynologically this section is characterized by a rich variation of trilete microspores as Densosporites fissus (Reinh.) E. Schulz, Cingulizonatus cf. 
inaequalis (Mädler) n. comb. Triancoraesporites ancorae E. Schulz, Polypodiisporites polymicroforatus (Orlowska-Zwolinska) n. comb. and several species of Semiretisporis. Furthermore the palynomorphs from these marly samples have a characteristic redbrown colour which has also been observed in other samples of Triletes-Schichten in the area (wells Örrel 1, Braudel 1) (Lund 1975).

\subsection{Lias alfa 1 - Lower alfa 2}

E 8 spl. 1101-1059 m: The Pinuspollenites Trachysporites Zone.

This section consists of mainly darkgrey clay, dated on microfauna, bivalves and in the upper part also on the basis of badly preserved ammonites.

The lowest part of this section (spl. $1101 \mathrm{~m}$ ) is intermediate in colour and lithology (marl) compared to the underlying Triletes-Schichten. This lower part contains the bivalves Unicardium cardioides (Bean.) Phil and Protocarida cf. rhaetica Oppel, the latter being a Rhaetic type according to Will (1969, p. 95 \& Abb. 41). As the Pre-planorbis Beds are present in the area (Hoffman 1963, fig. 1; and textfig. 1 here) it seems probable that this marly section should be assigned to the Pre-planorbis Beds.

E 8 spl. 1101-1094 $\mathrm{m}$ are from the lower part of Lias alfa 1 whereas spl. $1070 \mathrm{~m}$ is placed in the topmost part of Lias alfa 1 with Proarietites, just below the boundary to Lias alfa 2. Spl. $1059 \mathrm{~m}$ is from the lower part of Lias alfa 2 and is dated by the presence of Schlotheimia.

Palynologically the section (spl. 1101-1059 m) is characterized by the common presence of Pinuspollenites minimus (Couper) Kemp and Chasmatosporites hians Nilsson, and by the absence of Cerebropollenites macroverrucosus (Thierg.) E. Schulz. Trilete ornamented microspores are rare, Heliosporites altmarkensis E. Schulz and Trachysporites/Conbaculatisporites being the most common.

The lower part spl. 1101-1094 m is characterized by the common presence of Leiofusa jurassica Cooks. \& Eis. which are also found in abundance in the Lower Lias alfa 1 in other nearby wells. It should be noticed that Leiofusa jurassica is also present in the presumed Pre-planorbis Beds sample of Eitzendorf $8(\mathrm{spl} .1101 \mathrm{~m})$ but not in the Pre-planorbis Beds of Grevenhorst 1 and Westervanna $3 \& 4$ (see passage 7). In the latter wells the contact with the Planorbis Beds was not investigated and it is assumed that L. jurassica may also occur in the topmost Pre-planorbis Beds.

An impressive feature of the Lower Liassic of Eitzendorf 8 is the common presence of pollen like Pinuspollenites and Chasmatosporites relative to the microspores which are rare. In samples from the corresponding level in 
other localities relatively more microspores have been found. For instance, this is the case with a sample of brownish clay from the lower part of the Lias alfa 1 containing Psiloceras planorbis in the borehole Hohne 6. There the trilete smooth microspores are common and the group of ornamented trilete microspores comprises many "Liassic" specimens (of Uvaesporites, Heliosporites, Polycingulatisporites Trachysporites/ Conbaculatisporites etc.), whereas pollen like Pinuspollenites and Chasmatosporites are considerably less common than in Eitzendorf 8. From these and some similar aged microfloras in the boreholes Braudel 1 and Örrel 1 and the claypit "Schwarzen Berge" in Helmsand, one may conclude that much of the change in the single section is due to the depositional environment, although there was a change in the flora of the area between the "Rhaetic" and "Liassic" (many "Rhaetic" forms are absent or uncommon in the "Liassic"). Beds deposited under limnic or near shore marine conditions (Triletes-Schichten and basal Liassic of Hohne 6) contain relatively common specimens that are not easily transported in air or water (trilete microspores without gasfilled cavities and Corollina).

In offshore deposits as in Eitzendorf 8, the above mentioned types are relatively rare, and the microfloras are dominated by types easily transported (microspores with gas-filled cavities like Heliosporites, pollen with air sacks like Pinuspollenites) together with marine algae like Leiofusa. Furthermore it must be assumed that there is a stronger representation of the backland flora relative to the shore flora in the offshore deposits than in the nearshore deposits, as it is known from Tertiary and recent deposits (Jux 1968).

Much of the change in the microfloras on the Triassic/Jurassic boundary in the area, especially the increasing amount of Pinuspollenites is hence here ascribed to the marine transgression.

\subsection{Lias alfa 3}

E 8 spl. 1132-983 m: Zone with Cerebropollenites macroverrucosus.

This section consists of blueish marly clay dated by the "new microfauna datings".

Palynologically the section is characterized by the presence of Cerebropollenites macroverrucosus (Thierg.) E. Schulz. Pinuspollenites is common as in the underlying zone and "Clavatipollenites hughesi Couper" and Nevesisporites limbatus Playf. appear. In sample $1132 \mathrm{~m}$ Ricciisporites is still sporadically present. In sample $983 \mathrm{~m}$ tetrads of Uvaesporites sp. appear and Lycopodiumsporites (inclusive of L. semimuris Danze-Corsin \& Laveine) are common. Since Lycopodiumsporites are uncommon in other 
Lias alfa samples in the area, it appears that Lycopodiumsporites does not become prominent until during the topmost Lias alfa 3 . This is an important difference to the microfloras from Scania and Rødby, where $L$. is common also in the (Rhaetic and) Lias alfa.

The stratigraphical level with the incoming of Cerebropollenites macroverrucosus (Thierg.) E. Schulz is very important and it could probably be used for intercontinental correlations. Unfortunately, this level has not been precisely fixed in Eitzendorf 8 (lack of core material) or in the neighbouring area of East Germany, where E. Schulz \& Mai (1966) mention that $C$. macroverrucosus is absent in Lias alfa 1 and present in alfa 3 and doubtful in alfa 2 due to lack of samples dated by means of marine fossils. In $\mathrm{E} 8$ the youngest sample without $C$. macroverrucosus is derived from the lower part of Lias alfa 2 (about $1 / 3$ above the basis in the alfa 2 section), and the oldest sample with the species under discussion is derived from the basal part of Lias alfa 3. However, in the boring Braudel 1 doubtful specimens of $C$. macroverrucosus (with thin but distinct endexine) have been found in the upper part of Lias alfa 2 (basal part of Angulaten Sandstein), where both doubtful and typical C. macroverrucosus (with and without visible endexine) were present in the superimposed basal Lias alfa 3 . Hence, in the Aller area, there seems to be a succession of microfloras without $C$. macroverrucosus (up to lower part of Lias alfa 2) to such with doubtful $C$. macroverrucosus with endexine (around the upper part of Lias alfa 2) to microfloras with typical C. macroverrucosus (from Lias alfa 3).

\section{Palynology of the Pre-planorbis Beds to the Northwest}

The Pre-planorbis Beds are restricted to the northwestern part of the investigated area (text fig. 1) and rest on the limnic Triletes-Schichten and are superimposed by the marine Planorbis Beds. They consist of dark grey shales and greenish marls and may reach a thickness of 20 metres (Hoffman 1963).

Four samples from well dated Pre-planorbis Beds are examined here, two from Westerwanna 4 and two from Grevenhorst 2 (for depth of samples see appendix). Furthermore one sample representing the probable Preplanorbis Beds in Eitzendorf $8(1101 \mathrm{~m})$ is also investigated as mentioned on p. 24.

The palynomorph content in the well dated samples from Westerwanna 4 and Grevenhorst 1 are similar and of a distinctive Liassic character with many Pinuspollenites minimus (Couper) Kemp and Chasmatosporites hians Nilsson. The trilete ornamented microspores are rare but comprise only 
Liassic types like Heliosporites altmarkensis E. Schulz, Trachysporites fuscus Nilsson, T. asper Nilsson and Uvaesporites reissingeri (Reinhardt) $\mathrm{n}$. comb. Rhaetic types as well as the younger Cerebropollenites macroverrucosus (Thierg.) E. Schulz are absent. Hence this microflora belongs to the Pinuspollenites Trachysporites Zone. Corollina and trilete smooth microspores tend to be common suggesting together with the presence of marine palynomorphs (Michrystridium and Crassosphaera) a marine to brackish nearshore environment of deposition.

The content of palynomorphs in the probable Pre-planorbis Beds in Eitzendorf $8(1101 \mathrm{~m})$ differs from the above mentioned microflora by the presence of Leiofussa jurassica Cookson \& Eisenack. Presence of the last mentioned species, which is common in the Planorbis Beds, suggest that this Eitzendorf sample was deposited a little later and under more open-sea conditions than the Pre-planorbis Beds samples from Grevenhorst 2 and Westerwanna 4.

\section{Palynostratigraphy of Massbüll 1 \\ 8.1. Material}

Massbüll 1 is of special interest to the present investigation Since like Rødby 1 it is situated on the northern flank of the Northwest German Basin (textfig. 1), and because the Rhaetic ostracodes etc. are known from Massbüll 1, (Wicher 1957) and already have been compared with microfaunas of Danish boreholes (Christensen $1962 \&$ 1963).

In Massbüll 1 the Lower and Middle Rhaetic are well developed whereas the Upper Rhaetic and Jurassic are missing probably due to erosion. Below marine Middle Rhaetic dark shales with Taeonidon, Proteonina etc. (oberes Mittelrätschiefer sensu Schott) a sandy section is encountered. It comprises the remaining part of the middle Rhaetic and the uppermost part of the "lower Rhaetic" (zone 4 of Wicher with the megaspore Y843, probably Trileites pinguis, the dating being based on geophysical data). Under this sandy section follow dark shales with $A$. postera and ostracodes (Wicher zone 2 with 0807 ) underlain by dark shales with an intercalation of variegated greenish marl (Wicher zone 1 with 0 844, 845, 847, 850 and 851). This section (Wicher zone 1-2) thus belongs to the Postera-Schichten (Will 1969, Kozur \& Mostler 1972).

Only samples from selected sections (with bivalves etc.) are available from Massbüll 1. Five samples from Massbüll 1 have been examined (table 2). Spl. $1231 \mathrm{~m}$ is a dark shale taken just above the greenish marl in Wichers zone 1, spl. $1215 \mathrm{~m}$ is a dark shale from Wichers zone 2. Both samples 
represent the Postera-Schichten sensu Will. Spl. 1208 is from a thin medium grey clay layer in the upper part of the sandy "Lower Rhaetic" near the bottom or just below Wichers zone 4 . Spl. $1151 \mathrm{~m}$ is a dark clay with Taeniodon in the upper part of the Middle Rhaetic between the Hauptsandstein and the Flasersandstein, and spl. 1139 is a dark clay just above the last mentioned sandstone. Spl. $1151 \mathrm{~m} \& 1139 \mathrm{~m}$ represent the upper part of the Middle Rhaetic.

\subsection{Lower Rhaetic}

M. 1 spl. 1231 m \& 1215 m: The Granuloperculatipollis Subzone of the Corollina Enzonalasporites Zone.

The contemporary presence of Enzonalasporites, Eucommiidites major E. Schulz and numerous Corollina and in addition the presence of Granuloperculatipollis rudis Venk. \& Gocz. assign these samples to the Granuloperculatipollis Subzone of the Corollina Enzonalasporites Zone. As in Eitzendorf 8, Conbaculatisporites mesozoicus Klaus is absent in this subzone. Ovalipollis are more common than Ricciisporites but the latter are more common in Massbüll 1 than in Eitzendorf 8 (M. 1 spl. 1231 m: 28 Ov./ 19 Ric., spl. 1215 m: 57 Ov./ 31 Ric.).

\section{3. (Lower to) Middle Rhaetic transition}

M. 1 spl. 1208 m: The Ricciisporites Conbaculatisporites Zone.

The absence of both older and younger types like Enzonalasporites and Limbosporites lundbladi Nilsson, respectively, characterize this section together with the presence of numerous Ricciisporites and the presence of "Liassic" types among the trilete microspores (Conbaculatisporites mesozoicus Klaus, Lycopodiumsporites austroclavatidites cookson, Punctatisporites major (Couper) G. Schulz \& Hope etc.). Ricciisporites is considerably more common than Ovalispollis (6 Ov./ 68 Ric.).

The palynomorphs indicate a (topmost Lower to) basal Middle Rhaetic age when compared to Eitzendorf 8.

\subsection{Middle Rhaetic}

M. 1 spl. 1151 m \& 1139 m: The Rhaetipollis Limbosporites Zone.

Distinguished from the underlying zone by the presence of Limbosporites lundbladi Nilsson and from the superimposed Ricciisporites Polypodiisporites Zone by the regular presence of Rhaetipollis germanicus E. Schulz, Araucariacidites australis Cooks. and Corollina zwolinskai n.sp. Ricciispo- 
rites are common but not as common as Ovalipollis (spl. $1151 \mathrm{~m}$ : 43 Ov./ 15 Ric., spl. $1139 \mathrm{~m}: 8 \mathrm{Ov} . / 1 / 4 \mathrm{Ric}$.). The relatively small amount of Ricciisporites and furthermore the rare occurrence of trilete ornamented microspores in spl. $1151 \mathrm{~m} \& 1139 \mathrm{~m}$, are possibly due to differential sorting from the habiat of the palynomorph producing plants to the marine place of deposition, causing an overrepresentation of saccate pollen like Ovalipollis.

Compared with Eitzendorf 8 of the palynomorphs in M. spl. $1151 \mathrm{~m} \& 1139$ $\mathrm{m}$ indicate a Middle Rhaetic age.

\section{Palynostratigraphy of Rødby 1}

\subsection{Material}

The stratigraphical distribution of the pollen and microspores in Rødby 1 is shown on Table 3, and a systematical account follows in passage 17. Previous investigations and the lithology were treated in passage 2 and 4 . The succession of microfloras of Rødby 1 is adequately known in the Liassic, but in the Rhaetic some sections yield only barren samples (sandy facies). However, the microfloras found may be placed in the proposed scheme as noted below in the passage 9.2-9.7.

\subsection{Lower Rhaetic}

R 1 spl. 2345'-2295': The Corollina Enzonalasporites Zone.

This section is characterized by the contemporary presence of Corollina and Enzonalasporites. Spl. 2345' and spl. 2326' contain rich microfloras dominated by Corollina torosus (Reissinger) Klaus and are in addition to Enzonalasporites characterized by Eucommiidites major E. Schulz. Spl. $2295^{\prime}$ (not shown in Table 3 ) has yielded only a sparce and badly preserved microflora which, however, includes Enzonalasporites, placing this sample in the Corollina Enzonalasporites Zone.

\section{R 2345': The Corollina Porcellispora Subzone.}

This section is characterized by the contemporary presence of Corollina torosus (Reissinger) Klaus and Porcellispora longdonensis (Clarke) Scheuring. The first mentioned is dominating and the latter is common among the trilete ornamented microspores.

The Corollina Porcellispora Subzone has not been found in the present investigation of German boreholes, probably because samples from the basal part $(5-10 \mathrm{~m})$ of the Postera-Schichten have not been available there. In Poland (p. 40), however, microfloras placed in this subzone, are known in 
deposits believed to equivalate the Saurichthys-Schichten to basal PosteraSchichten. To this section then spl. $2345^{\prime}$ must be referred to on the basis of palynomorphs. Because a correlation with the Postera-Schichten is indicated by lithology and the presence of doubtful $A$. postera (acc. DGU internal data), spl. $2345^{\prime}$ most likely has to be correlated with the basal PosteraSchichten.

R 1 spl. 2326': The Granuloperculatipollis Subzone.

This part of Rødby 1 belongs to the Granuloperculatipollis Subzone due to the common presence of G. rudis Venk. \& Gocz. in a Corollina Enzonalasporites microflora dominated by Corollina torosus (Reissinger) Klaus.

Spl. 2326' has to be correlated with the (middle) Postera-Schichten of Eitzendorf 8 and Massbüll 1 (E 8 spl. 1205 m-1199 m, M. 1 spl. 1231 m \& 1215 $\mathrm{m})$.

\subsection{Middle Rhaetic}

R 1 spl. 2163'-1930': The Rhaetipollis Limbosporites Zone. Spl. 2163'-1930' belongs to the Rhaetipollis Limbosporites Zone due to the presence of both Rhaetipollis germanicus E. Schulz and Limbosporites lundbladi Nilsson.

The microflora in the lowermost sample (2163') is somewhat similar to the microfloras found near the Lower to Middle Rhaetic boundary in Eitzendorf 8 and Massbüll in the Enzonalasporites Conbaculatisporites Subzone compared to the Ricciisporites Conbaculatisporites Zone. This similarity is shown by a fair amount of Conbaculatisporites/Trachysporites and absence of Cingulizonates rhaeticus (Reinh.) E. Schulz a species normally found together with Limbosporites lundbladi Nilsson in the Middle Rhaetic. However, presence of Polypodiisporites polymicroforatus (Orlowska-Zwolinska) n. comb. and Araucariacicites australis Cookson as well as the absence of types restricted to the Lower Rhaetic and older strata indicate that the Lower Rhaetic is still not penetrated at $2163^{\prime}$. This is also proved by the presence of Limbosporites lundbladi Nilsson. Altogether the evidence mentioned indicate a Middle Rhaetic, probably early Middle Rhaetic age for spl. 2163'.

Concerning the distinction of the microfloras found in spl. 2163'-1930' from the microfloras in the overlying Ricciisporites Polypodiisporites Zone, the main criterion is the top at about $1930^{\prime}$ of regular to common Rhaetipollis germanicus E. Schulz, Corollina zwolinskai n. sp. Protohaploxypinus hercynicus (Mädler) n. comb., etc., as well as the absence of the rich variation of trilete ornamented microspores found in spl. 1888' $-1860^{\prime}$.

The acme of conifer pollen (Corollina spp. etc.) and of marine palynomorphs (Micrhystridium spp. etc.) in spl. 1930' compared with the 
nearby terrestrial microflora with many microspores in spl. $1888^{\prime}-1860^{\prime}$ strongly suggests that the microfloral changes at the boundary between the Rhaetipollis Limbosporites Zone and the Ricciisporites Polypodiisporites Zone are facies controlled at least in Rødby 1.

Concerning the content of palynomorphs R $2163^{\prime}-1930^{\prime}$ has to be correlated with the Contorta-Schichten (basal part excluded) the NW German Basin (E 8 spl. 1149 m-1128 m, M 1 spl. 1151 m-1139 m) and the Vallåkra and Mine Formations in Scania (S spl. 1-6).

\subsection{Upper Rhaetic}

R 1 spl. 1888'-1960': The Ricciisporites Polypodiisporites Zone.

This section is characterized by the common content of Polypodiisporites polymicroforatus (Orlowska-Zwolinska) n. comb. (spl. 1862'-1860') or of Semiretisporis (spl. 1888'), and further by a rich variation of trilete ornamented microspores, which are rare and often only found beyond the counting. Often the specimens have the characteristic reddish dark brown colour, observed in the typical Triletes-Schichten. Presence of a single specimen of Rhaetipollis germanicus E. Schulz found in spl. $1862^{\prime}$ is possible due to reworking.

By the content of palynomorphs R 1888-1860 must be correlated to the Triletes-Schichten in Eitzendorf 8 and other wells in the area of the Aller River.

\subsection{Topmost Upper Rhaetic?}

R spl. 1843' \& 1842': Not referred to any zone.

The microflora in this controversial interval, which was placed in the Rhaetic by Sorgenfrei \& Buch (1964) and in the Liassic by Bertelsen and Michelsen (1970) is here referred to the Rhaetic due to abundance of Ricciisporites tuberculatus Lundblad relative to Pinuspollenites minimus (Couper) E. Kemp. (spl. 1843: 30 Ric./ 1 Pin.).

The microspore flora comprises many Rhaetic species (Lycopodiacidites rhaeticus E. Schulz, Camerozonisporites laevigatus E. Schulz, Densosporites fissus (Reinh.) E. Schulz, Densosporites cavernatus (Orlowska-Zwolinska) n. comb., Limbosporites lundbladi Nilsson, Semiretisporites, Perinotriletes thuringiacus E. Schulz etc.) most of which are rare and only found outside the counting, in contrast to the mainly Liassic species (Punctatisporites major (Couper) G. Schulz \& Hope, Deltoidospora toralis (Lesch.) n. comb., Trachysporites/Conbaculatisporites, Bacultisporites and Aratrisporites minimus E. Schulz which are more com- 
mon and normally found in the counting. Hence the microspore flora has a Rhaetic aspect qualitatively but a Liassic aspect quantitatively.

The pollen flora is mainly Rhaetic with common Ricciisporites and presence of species like Araucariacidites australis Cooks. Protohaploxypinus hercynicus (Mädler) n.comb. and Taeniasporites rhaeticus E. Schulz, which in the German wells occur regularly in the Rhaetipollis Limbosporites Zone i.e. in the Middle Rhaetic. Characteristic is also common presence of Quadraeculina anellaeformis Bolch (spl. 1843': 18 Quadr./ 1 Pinuspollenites).

The Microflora found in spl. 1843' \& $1842^{\prime}$ is not known from the German wells investigated, however in Scania a sample from the basal Lias (Boserup Beds. Sample 7) contained a similar microflora, which differed by the more common presence of Pinuspollenites than of Ricciisporites. On account of the latter flora spl. $1843^{\prime} \& 1842^{\prime}$ must be placed a little lower in the microfloral succession than the mentioned sample from the Boserup Beds if the increase of Pinuspollenites relative to Ricciisporites occurs at the same time in Rødby 1 and in Scania. Most likely 1843 \& 1842 then belong to the top of the Rhaetic but a Pre-planoberis Bed age cannot be completely ruled out.

A place close to the Rhaetic Liassic boundary is also indicated by the succession of facies (spl. 1862'-1859', no marine microflora; spl. 1843' \& $1842^{\prime}$, sparce marine microflora; spl. 1839', rich marine microflora) and makes a stratigraphical gap between spl. 1843' and spl. 1839' unlikely.

\subsection{Lias alfa $1-2$}

R 1 spl. 1839'-1631': The Pinuspollenites Trachysporites Zone.

This section belongs to the Pinuspollenites Trachysporites Zone and is distinguished from the underlying zone by containing more Pinuspollenites than Ricciisporites, and also from the superimposed unnamed zone by the absence of Cerebropollenites macroverrucosus (Thierg.) E. Schulz. A high frequency of Chasmatosporites is also distinctive towards the underlying zone. Heliosporites altmarkensis E Schulz, Trachysporites and Baculatisporites are the most common trilete ornamented microspores. Deltoidospora toralis (Lesch.) n. comb. is common as in R 1843' giving the microfloras in Rødby 1 greater similarity to those of Scania compared to of the Aller Area. The samples 1721' and 1674' are influenced by deltaic sedimentation (Michelsen 1973) and contain a more diverse microflora than the underlying and superimposed Liassic part of Rødby 1. Some of the species in these two samples are in common with the Rhaetic (Perotriletes globosus (Leschik) n. comb., Stereisporites punctus (Klaus) Krutzsch etc.) and some are unique to this level in Rødby 1 (Clavatipollenites hughesi Coup. and 
Ephedripites torosus Mädl.). There is no doubt that the presence of this microflora relatively rich in species is due to the deltaic sedimentation. However, it is of note that the 'Rhaetic' species are not known from higher stratigraphic levels in the area.

On the base of microspores and pollen spl. 1839'-1631' has to be correlated with Lias alfa 1-2 in the Aller Area and of Scania.

\subsection{Lias alfa 3 (topmost alfa 2 not totally excluded)}

R 1 spl. 1561'-1560': unnamed zone above the Pinuspollenites Trachysporites Zone.

This part of Rødby 1 is characterized by the presence of Cerebropollenites macroverrucosus (Thierg.) E. Schulz and Lycopodiumsporites. Of the former only one (doubtful) specimen (pl. 7 fig. 14) has been found, which possibly is only an extreme variant of $C$. thiergarti E. Schulz which are more common and comprise specimens with the ektexine loosened from the endexine like those of the upper Lias alfa 2 and basal alfa 3 of Braudel 1 in the area of the Aller River.

The presence of Lycopodiumsporites semimuris Danz. \& Lav. and tetrads of Uvaesporites sp. indicates a Lias alfa 3 age when compared with the Aller Area and Scania. Common presence of L. austroclavatidites (Cooks.) also indicates a Lias alfa 3 age when compared with the former area, but in the latter area this species is also common in Lias alfa 1-2. The presence of rare Ricciisporites tuberculatus Lundblad, Cingulizonates rhaeticus (Reinh.). E. Schulz and Trachysporites tuberosus Nilsson etc. excludes an age much younger than Lias alfa (2).

Based on microspores and pollen R $1560^{\prime}-1561^{\prime}$ then has to be correlated with Lias alfa 3 (basal part) in the area of the Aller River and of Scania. A topmost Lias alfa 2 age cannot be totally excluded, however.

\subsection{Combined lithologic and palynologic correlation of Rødby 1 with NW Germany}

The palynological correlation of Rødby 1 given above in (9.2.-9.7.) corresponds to the lithologic correlation proposed on p. 14, where R 2122'-2200' was placed in the Middle Rhaetic and no lithostratigraphic significance was given to the red clay in the upper half of the mentioned section.

By combination of the palynostratigraphy and lithostratigraphy the following correlation may be proposed for Rødby 1: 
1550 '-1561' u.KB.: Lias alfa 3

$1631^{\prime}-1753^{\prime}$ u.KB.: Lias alfa $2(-? 1)$

$1753^{\prime}-1839^{\prime}$ u.KB.: Lias alfa $1(-? 2)$

1839'-1859' u.KB.: Topmost Upper Rhaetic?

1859'-1919' u.KB.: Upper Rhaetic, Triletes-Schichten

1919'-2200' u.KB.: Middle Rhaetic, Contorta-Schichten

2200'-2349' u.KB.: Lower Rhaetic, Postera-Schichten

$2349^{\prime}-2414^{\prime}-$ ? : Norien, Saurichthys-Schichten

This correlation fits with that of Bertelsen and Michelsen (1970) with regard to the topmost part of the Liassic section. Concerning the Rhaetic Liassic boundary the present correlation is intermediate to that of the mentioned authors and that of Sorgenfrei and Buch (1964) since the 1837,5'-1839' u.KB. is referred to as Liassic and $1839^{\prime}-1859^{\prime}$ u.KB. to the Rhaetic. However, it must be admitted that the last mentioned section cannot be correlated with certainty either to the Liassic or the Rhaetic. Concerning the lower boundary of the Rhaetic inclusive of Lower Rhaetic sensu germanico the present correlation is nearly identical with that of Sorgenfrei and Buch (1964).

\section{Scania}

\subsection{Introduction}

The macrofaunas and lithostratigraphy of the Upper Triassic and Lower Liassic of Scania were treated by Troedson (1951) who recognised the following formations:

Döshult F. (Lias alfa 3)

Helsingborg Formation (Lias alfa 1-2)

Mine Formation (Rhaetic)

Vallåkra Formation (Rhaetic)

Kågerød Formation (Keuper)

The ages were based mainly on ammonites in the Döshult Formation and lamellibranchs in the Helsingborg- and Vallåkra Formation, and also on macrofloras in the Mine- and the Helsingborg, Formation. The Kågeröd Formation consists of reddish clay and sand, the Vallakra Formation of brownish non-lamellated clay and sand, the Mine Formation of darkgrey lamellated clay, coal and sand. The Helsingborg Formation resembles the Mine Formation except for some light clay at the base (Boserup Beds). The Döshult formation consists mainly of dark grey clay (Troedson 1951 etc.). 
The Rhaeto-Liassic macrofloras of Scania became known early through the classical investigations by Nathorst (1872 etc.). On the basis of Nathorst's work Harris (1937) concluded that an older (Rhaetic) Lepidopteris flora and a younger (Lias alfa) Thaumatopteris flora was present. Troedson (1951) later stated that the deposits where Nathorst and others had found the Lepidopteris flora belonged to the Mine Formation (Rhaetic), and that those with the Thaumatopteris Flora belonged to the Helsingborg Formation (Lias alfa 1-2). The floras at the Rhaetic Liassic boundary sensu Troedson were, however, poorly known, until they were investigated by Lundblad (1951). She found that both the index species of the Lepidopteris Zone (L. ottonis) and the Thaumatopteris Zone ( $T$. shenki) occurred together in the upper part of the Mine Formation (in a shale intercalation in coal A at Billesholm and in an erosion rest of black shale above coal A at Hyllinge) and in the Boserup Beds. The mixed flora of these deposits hence equals the flora in the "Transition Region" between the Lepidopteris Zone and the Thaumatopteris Zone in the Scoresby Sound Area, the section in which Harris presumed that the Rhaetic Liassic junction had to be placed (Harris 1937). On the basis of the macroflora the Rhaetic Liassic junction in Scania then has to be placed somewhere in the section including coal A and the Boserup Beds, and cannot be precisely placed on the basis of the present known macrofloras. However, this does not preclude that unmixed Lepidopteris floras and unmixed Thaumatopteris floras are dated as Rhaetic and Lower (-? middle) Liassic, respectively.

Nilsson (1958) studied pollen and microspores from the Sapropel at Sandåkra and five Rhaetic to Lower Liassic reference samples from Scania. These five samples are also used for reference here (see passage 10.2 \& 10.3). Orbell (1973) noted the microflora of ten museum samples from Rhaetic to Lower Liassic plant beds of Scania. Based on the presence of Rhaetipollis germanicus E. Schulz he compared the Lepidopteris Zone with his Rhaetipollis Zone known from the British Rhaetic basal Cotham Beds to Tea Green Marls (ca. = Middle to Lower Rhaetic in Germany). Tralau (1975) published selected palynomorphs from the Vallakra Formation and dated it as Middle to Upper Rhaetic. On basis of Rhaetipollis germanicus E. Schulz, Cingulizonates rhaeticus (Reinhardt) E. Schulz and other miospores found by Tralau (l.c.) I consider the Vallakra Formation to be of Middle Rhaetic age. However, because Tralau (1.c.) did not note Limbosporites lundbladi Nilsson this age assignment is tentative. 


\subsection{Origin of samples}

The localities and stratigraphical level from where the samples shown on Table 4 originate are described in detail below. Especially noteworthy is the fact that sample 5, the "type sample" of Limbosporites lundbladi Nilsson was prepared and considered by Nilsson to be Liassic, is shown to be (Middle) Rhaetic.

Scania spl. 1 is the sample from Bjuv investigated by Nilsson (1958). Nilsson's slide "Bjuv 129" was reinvestigated here. The sample originates from the "alfa layer" of Nathorst and consists of greybrown shale (Nilsson 1958 , p. 23). It probably represents the top of the Vallakra Formation, to which Troedson (1951, p. 100) partly classified the fireclay below the Rhaetic coal B.

Scania spl. 2-4 are from coal B and the superimposed and underlying shales in the clay and coal pit of Lunnom in the Billesholm Area. S. spl. 2 represents a light greybrown non-lamellated clay, 1,5 metre below coal B.S. spl. 3 is a sample of coal collected $10-15$ centimetres above the base of Coal B.S. spl. 4 represents a darkgrey clay lamella 1,3 metre above the base of Coal B. Due to the lithological facts mentioned above. S. spl. 2 probably represents the top of the Valakra Formation and S. spl. 3-4 with certainty the Mine Formation.

S. spl. 5 represents Nilsson's slide "Höganäs 102" prepared from: "Schwarzer Schiefer mit Schizoneura hoerniensis aus dem unteren Lias (Thaumatopteris Zone) von Höganäs (Nya schaktet)" (Nilsson 1958, p. 23). According to Harris (1931 p. 22, 1937 Table No. 2) Neocalamites (al. Schizoneura) hoerniensis is restricted to the Rhaetic in Scania, and according to Nathorst (1878 p. 7) black shale with $S$. hoerniensis from "Nya schaktet", originates from shale intercalations in Coal B ("Fru Bagges Flöts") or from a (slightly) higher layer. Therefore, it may be concluded that the sample under discussion most certainly originates from the Rhaetic Mine Formation (probably lower part) and not from the Liassic as claimed by Nilsson.

The proposed transfer of Nilsson's "Höganäs sample" (spl. 5 here) from the Liassic to the Rhaetic is noteworthy since the holotype of the stratigraphically important species: Limbosporites lundbladi Nilsson originates from this sample.

S. spl. 6 is a dark clay above Coal A from "Vallåkra norra Skifferbråt" and does therefore represent the top of the Rhaetic Mine Formation.

S. spl. 7 originates from "Vallåkra norra Skifferbråt" and does therefore represent the top of the Rhaetic Mine Formation.

S. spl. 7 originates from "Vallåkra södra Skifferbråt" and represents a 
greenish lightgrey marly clay from the Boserup Beds. According to the stratigraphy of Troedson this sample represents the basal Liassic.

S. spl. 8 represents Nilsson's slide 'Pålsjö 122'”. It originates from the middle part of the lower Helsingborg Stage (cyclus 6 according to Troedson 1951) of Lias alfa $1(-2)$ age.

S. spl. 9 is from Elinebergbrottet in Helsingborg and represents a sample of dark shale from the top of the lower Helsingborg Stage (cyclus 7 of Troedson 1951) of Lias alfa $1(-2)$ age.

S. spl. 10 represents Nilsson's slide "Höör 91" and a new preparation of the same sample. It is probably of the same age as the upper Helsingborg Stage, probably Lias alfa 2.

S. spl. 11 represents Nilsson's slide "Tosterup 142". According to Troedson (1951, p. 122), this locality belongs to the Thaumatopteris Zone, but cannot be correlated closer to other Lower Liassic deposits in Scania,

S. spl. 12-13 originates from the clay pit of Gantofta and represents dark clay of Lias alfa 3 (Lower Sinemurien) and Lias beta (Upper Sinemurien) age, respectively. Sample 12 is collected at the eastern corner of the road down in the clay pit just above a sandstone, stratigraphically roughly 50 metres below the base of reddish clay in the pit. Sample 13 is collected in dark clay, immediately below the base of reddish clay, and is dated by ammonites to Lias beta (Upper Sinemurien) (Reyment 1969).

\subsection{Palynostratigraphy of Scanish samples}

\subsubsection{Middle Rhaetic}

Scania spl. 1-6 topmost Vallåkra Formation (?) and Mine Formation: The Rhaetipollis Limbosporites Zone.

Presence of Limbosporites lundbladi Nilsson and Rhaetipollis germanicus E. Schulz indicate an assignment to the Rhaetipollis Limbosporites Zone, as do also the presence of Cingulizonates rhaeticus (Reinhard) E. Schulz and Corollina zwolinskai n.sp. The more common presence of Ricciisporites tuberculatus Lundblad in contrast to Pinuspollenites minimus (Couper) Kemp (S. spl. 6: 5 Ov., 74 Ric., 3 Pinusp., 4 Quadraeculina) distinguishes this zone from the superimposed Pinuspollenites Trachysporites Zone.

Based on palynomorphs S. spl. 1-6 have to be correlated with the Contorta-Schichten in the Northwest German Basin (E. 8 spl. 1149 m-1129 m, M. spl. $1151 \mathrm{~m} \& 1139 \mathrm{~m}$ ) and their presumed equivalents in Rødby 1 (spl. 2163'-1930'). 


\subsubsection{Lias alfa $1-2$}

Sp.spl. 7, Boserup Beds, basal Helsingborg Formation: (?) The Pinuspollenites Trachysporites Zone.

Referred to this zone on the basis of the more common presence of Pinuspollenites minimus (Couper) Kemp than of Ricciisporites tuberculatus Lundblad which is still common, however, Notable is also the common presence of Quadraeculina anaellaeformis Malj. (S. spl. 7: 19 Ric., 39 Pinusp., 29 Quadraeculina). The microspore flora shows a mixing of both rare "Rhaetic" types (Cingulizonates rhaeticus (Reinh.) E. Schulz, Limbosporites lundbladi Nilsson, Semiretisporis, Lycopodiacidites rhaeticus E. Schulz etc.) and more common "Liassic" types (Punctatisporites major (Couper) Kedves \& Simoncsics, Baculatisporites comaumensis (Cookson) Potonie, Trachysporites spp. etc.). The correlation with the similar microflora in Rødby 1 spl. 1842' \& 1843' was discussed in passage 9.5.

S. spl. 8-10, the Helsingborg Formation: The Pinuspollenites Trachysporites Zone.

The common presence of Pinuspollenites minimus (Couper) Kemp and the absence of Cerebropollenites macroverrucosus (Thierg.) E. Schulz and of "Rhaetic" types like Limbosporites lundbladi Nilsson etc. causes the assignment of this section to the Pinuspollenites Trachysporites Zone. Heliosporites altmarkensis E. Schulz is absent but Lycopodiumsporites austroclavatidiites Cookson is common among the trilete arnamented microspores. By this the Scanic microfloras differ from those of the Aller Area, where the situation is the reverse.

Dated by palynomorphs S. spl. 8-10 correlate with Lias alfa 1-2 in the NW German Basin.

\subsubsection{Lias alfa 3 - beta}

S. spl. (11) 12-13: Unnamed zone above the Pinuspollenites Trachysporites Zone.

Characterized by the presence of Cerebropollenites macroverrucosus (Thierg.) E. Schulz. Presence of Ricciisporites and Trachysporites fuscus Nilsson in sample 12 gives this Lias alfa 3 sample some similarity with the underlying Lias alfa, from which, however, it differs by the presence of Lycopodiumsporites semimuris Danze-Corsin \& Laveine.

Nilsson (1958) states the presence of Cerebropollenites macroverrucosus in the Tosterup sample (S. spl. 11), which as mentioned above belongs to the Thaumatopteris flora, but was not dated more exactly. If $C$. macroverrucosus (Thierg.) E. Schulz is present in the Tosterup sample as stated by 
Nilsson then the limnic deposits at Tosterup are more or less synchronous with the marine deposits (Döshult Beds) in the central part of the basin.

The microfloras of S. spl. 11-12, which are sufficiently dated by marine fossils agree with those of similar age in the NW German Basin (E. $8 \mathrm{spl}$. $1021 \mathrm{~m} \mathrm{\&} 984 \mathrm{~m}$ ) where C. macroverrucosus (Thierg.) and partly also Lycopodiumsporites semimuris Danz. \& Law. also are present. This similarity between marine dated samples increases the stratigraphical value of the microspore zonation here proposed.

\subsection{Correlation of macroflora - and microflora zonation}

By comparison of the macroflora zonation (10.1.) with the pollen and microspore zonation (10.3.) it is seen that the deposits with an unmixed Lepidopteris flora in Scania (S. spl. 1-5) belong to the Middle Rhaetic Rhaetipollis Limbosporites Zone. Furthermore, it is apparent that the deposit with a mixed Thaumatopteris Lepidopetris flora partly belongs to the Middle Rhaetic Rhaetipollis Limbosporites Zone (S. spl. 6) and partly to the Liassic Pinuspollenites Trachysporites Zone (S. spl. 7). Finally, it is seen that the deposits with an unmixed Thaumatopteris flora partly belong to the Pinuspollenites Trachysporites Zone (S. spl. 8-10) partly to the unnamed superimposed zone with Cerebropollenites macroverrucosus (Thierg.) (S. spl. 11), indicating a Lias alfa 1-3 age of the Thaumatopteris flora in Scania.

The sapropel at Sandåkra, the stratum typicum of Chasmatosporites Nilsson, belongs to the "unnamed zone with Cerebropollenites macroverrusus", due to the presence of this species. Callialasporites was neither observed by Nilsson (1958) nor by me. Hence the age of the sapropel is "Middle" Liassic (Sinemurian or Plinsbachian).

\section{Poland}

\section{1. (Litho-)stratigraphy}

The succession of pollen and microspores in the Upper Triassic and Lower Jurassic of Poland is well-known qualitatively and quantitatively from a number of publications (Rogalska 1954, 1956 \& 1962, Orlowska-Zwolinska 1966, 1967, 1971 etc.). However, many of the names used in the Polish literature to distinguish palynomorphs as well as stratigraphical units differ from those used in Western Europe. A lithostratigraphical and palynostratigraphical correlation between Poland and the NW German Basin is attempted below (see also text-fig. 5). The correlation is based both on 
literature studies, discussions with Polish colleagues and my own investigation of Polish holotypes. The succession of microspores and pollen in the Upper Triassic and Lower Liassic of Poland is clearly shown on table 1 in Orlowska-Zwolinska 1967, on which the discussion in passage 11.2. is mainly based.

The lithostratigraphy of the Upper Keuper and Lower Liassic in Poland resembles that of the NW German Basin with the exception that the light greenish clays of the Triletes-Schichten are generally absent, so that the Rhaetic Liassic boundary may not be fixed lithostratigraphically in Poland. However, the succession from gypseous deposits to deposits with variegated clay to deposits with dark clay also occur in Poland (Seitz \& Wicher 1950, Dadlez \& Kopik 1963, Dadlez 1964 \& 1967 and Kopik 1967). The following correlation of the Polish Upper Triassic with the NW German Basin is therefore evident:

$\begin{array}{lll}\text { Poland } & \text { Poland } & \text { NW German Basin } \\ \text { Seitz \& Wicher } & \text { Dadlez \& Kopik } & \text { Will 1969 } \\ 1950 & 1963 & \text { (textfig. 2 this paper) }\end{array}$

$\begin{array}{lll}\text { Rät } & \text { Weilichowo Ser. } & \begin{array}{l}\text { (Triletes-Schichten \&) } \\ \text { Contora-Schichten } \\ \text { Konglomeratmergel }\end{array} \\ & \begin{array}{l}\text { Zbaszynek Ser. \& } \\ \text { Jarkowo Ser. \& } \\ \text { Drawno Ser. }\end{array} & \begin{array}{l}\text { Saurichtys-Schichten } \\ \text { Daw }\end{array}\end{array}$

Gibsmergel Up. Gypsum Ser. Ob. Gipskeuper

The above proposed correlation of Poland with the NW German Basin corresponds roughly to that proposed by Dadlez \& Kopik (1963, table 4). The main difference is that the upper part of the Zbaszynek Series here is correlated with the Lower Rhaetic Postera-Schichten and not with the Middle Rhaetic Contorta-Schichten as proposed by Dadlez and Kopik. This is done because of the variegated clay colours in the Zbaszynek Series, and because the microfauna thought to be Middle Rhaetic by Dadlez and Kopik may also be found in the Lower Rhaetic (Kozur 1972, p. 396).

\subsection{Palynostratigraphy}

\subsubsection{Norian to basal Lower Rhaetic}

The pollen and microscospore floras of the topmost Upper Gypsum Keuper, Drawno and Jarkowo Series contain many Porcellispora longdonensis (Clarke) Scheuring (al. B. kajperianus ac. to Orlowska-Zwolinska 
1971), Enzonalasporites and Corollina (al. Cheirolepidaceae, more than $50 \%$ ). Hence this section belongs to the Corollina Porcellispora Subzone of the Corollina Enzonalasporites Zone.

\subsubsection{Topmost Lower Rhaetic}

The Zbaszynek Series are barren in their lower part but contain in their upper part (Gorzow beds on Orlowska-Zwolinska's scheme) a microflora with numerous Corollina, Ricciisporites and Enzonalasporites. Hence this section belongs to the Corollina Enzonalasporites Zone. The probable presence of Uvaesporties reisingeri (Reinhart) n. comb. (al. Selaginella halli) suggests an assignment to the Enzonalasporites Conbaculatisporites Subzone. A correlation of the Upper Zbaszynek Series/ Gorzow beds with the Postera-Schichten is therefore highly probable when the microflora is considered. This is in accordance with the above proposed lithostratigraphical correlation, but contrary to the opinion of Orlowska-Zwolinska who followed the view of Dadlez and Kopik (l.c.) and correlated this sequence with the Middle Rhaetic Contorta-Schichten. However, a correlation with the Contorta-Schichten is unlikely, mainly due to the presence of common Enzonalasporites but also due to the absence of Limbosporites lundbladi Nilsson and of Cingulizonates rhaeticus (Reinh.) E. Schulz (al. C. delicatus) both of which are common among the trilete ornamented microspores in most of the Contorta-Schichten.

\subsubsection{Middle (to Upper ?) Rhaetic}

The Weilichowo Series contain a rich microflora with common Ovapollis, numerous Ricciisporites and a rich variation of "Rhaetic" microspore species. These comprise regular to common Limbosporites lundbladi Nilsson, Cingulizonates rhaeticus (Reinh.) E. Schulz, Semiretisporis, Cingulizonates $\mathrm{cf}$. inequalis Mädler) n.comb. (al. C. tuberosus $=$ Densosporites cingulatus E. Schulz), Densosporites cavernatus Orl.-Zwol. $\quad(=D$. foveocingulatus E. Schulz), Triancoraesporites, Aratrisporites fimbriatus (Klaus) Mädler (al. Saturnisporites spinosus), doubtful Marattisporites (al. Cyataceae-Schizeaceae) etc. Polypodiisporitis polymicroforatus (Orl.-Zwol.) n. comb. (=Convolutispora microrugulatalmicrofoveolata E. Schulz) are also present, but only with with few specimens. The presence of palynomorphs listed above indicates an assignment to either the Rhaetipollis Limbosporites Zone or the Ricciisporites Polypodiisporites Zone. Common presence of Ricciisporites (30-50\%), Limbosporites (10-30\%) and of Cingulizonates rhaeticus (10-30\%) points to the Rhaetipollis Limbosporites Zone as does also the rare presence of Polypodiisporites. However, since 
Rhaetipollis germanicus E. Schulz is not known from Poland, and as it is not known whether or not other species with a similar range (Corollina zwolinskai n. sp.) occur in the Weilichowo Series an assignment to the Ricciisporites Polypodiisporites Zone cannot be totally excluded.

Orlowska-Zwolinska (1966 \& 1967) correlated the Weilichowo S. with the Upper Rhaetic Triletes-Schichten, due to the presence of the above mentioned microflora. However, E. Schulz has expressed (acc. to oral information from Orlowska-Zwolinska) the opinion that the species in the Weilichowo S. are also present in the Middle Rhaetic. This is also evident from the stratigraphical table of E. Schulz (1967).

The Weilichowo S. consists of sand with dark clay (Dadlez \& Kopik 1963, Orlowska-Zwolinska 1967). Lithostratigraphically the Weilichowo S. then correlates with the Contorta-Schichten (text-fig. 2). The lithostratigraphical correlation is then consistent with the palynostratigraphical correlation proposed above. It seems probable that the Upper Rhaetic is absent in Poland as it probably also is in Scania.

\subsubsection{Lias (alfa $1 \& 2$ )}

The Rhaetic Liassic boundary in Poland can only be determined on basis of the microfloras and is placed where the Nathorstisporites hopliticus Jung megaspore flora appears (Marcienkiewiez 1971).

Among the microspores and pollen this boundary is marked by the appearance (in the Liassic) of Aratrisporites minimus E. Schulz (al. Lycostrobus scotti), Chasmatosporites, Quadraeculina anellaeformis Mal. (al. Pityopollenites bitorosus), Cerebropollenites thiergarti E. Schulz (al. Pollenites macroverrucosus) etc. However, Pinuspollenites minimus (Couper) Kemp (al. Pinus typ. silvestris) does not increase in frequence. The Rhaetic Liassic boundary is thus less apparent in Poland than in the Northwest German Basin and in Scania. Still, parts of the same succession can be recognized. (Data: Rogalska 1954 \& 1956, Orlowska-Zwolinska 1966 \& 1967, identifications discussed with the mentioned authors).

To sum up it may be said that the lithostratigraphy and palynostratigraphy of Poland, including the proposed correlation of the Upper Zbaszynek S. (Gorzow B.) with the Upper Postera-Schichten, is closely similar to that of the Northwest German Basin in the Lower and Middle Rhaetic, but somewhat different in the Upper Rhaetic to Lower Liassic, where the Upper Rhaetic seems to be absent and where the basal Liassic shows no increase in Pinuspollenites. 


\section{DDR (East Germany)}

\section{1. (Litho-)stratigraphy}

The Keuper and Liassic microfloras of DDR are well-known (Reinhardt 1962 \& 1964, E. Schulz 1966, 1967 etc.) and dated by marine fauna in the Liassic and mainly by lithostratigraphy in the Rhaetic. Below in the text the litho- and palynostratigraphy of the Rhaetic deposits and the palynostratigraphy of the Lower Liassic deposits are discussed and correlated with the microspore zones defined in this paper.

The succession of Upper Keuper deposits in the DDR is in most areas closely similar to the Northwest Germany and is well documented by data from wells at Marnitz. Marnitz exposed deposits with anhydrite and gypsum (Rote Wand) superimposed by variegated clay- and marlstones; without sand in the lower part (Steinmergelkeuper) and with intercalations of sand in the upper part (Unter Rhät). Above follows sandstone with dark grey clay (Mittel Rhät) superimposed by marly siltstone (Ober Rhät) which is brownish (below) or light greenish (above) (Weinholz 1960). These deposits may be correlated lithologically with those of NW German Basin (text-fig. 2) in the following way:

\begin{tabular}{ll} 
DDR & NW German Basin \\
\hline Obber Rhät & Triletes-Schichten \\
Mittel Rhät & Contorta-Schichten \\
Unter Rhät & Postera-Schichten \\
Steinmergelkeuper & Saurichthys-Schichten \\
Rote Wand & Oberer Gipskeuper
\end{tabular}

Marine Pre-planorbis Beds are not present in DDr (Schumacher \& Sonntag 1964 ) and the lowermost marine Liassic is only developed to the NW (E. Schulz 1967). The lower boundary of the Liassic is hence relatively badly dated by means of marine fossils in the DDR.

\subsection{Palynostratigraphy}

\subsubsection{Probable Lower Rhaetic}

The topmost Middle Keuper/Steinmergelkeuper sensu E. Schulz contains a characteristic microflora with numerous Corollina and regular to rare Enzonalasporites, Granuloperculatipollis rudis Venk. \& Gocz., Ricciisporites and Eucommiidites major E. Schulz (E. Schulz 1966 \& 1967). This microf- 
lora indicates an assignment ot the Corollina Enzonalasporites Zone probably to the Granuloperculatipollis Subzone.

The Lower Rhaetic sensu E. Schulz does not contain any pollen and microspores (E. Schulz \& Mai 1966, E. Schulz 1967).

\subsubsection{Middle Rhaetic}

The Middle Rhaetic contains a rich microflora with Rhaetipollis germanicus E. Schulz, common Ricciisporites and a variation of microspores including Limbosporites lundbladi Nilsson, Cingulizonates rhaeticus (Reinhardt) E. Schulz, Triancoraesporites etc. The Middle Rhaetic of the DDR hence belongs to the Rhaetipollis Limbosporites Zone. The variation of microspores, which is richer than known from NW Germany, is probably due to more limnic conditions in DDR than in NW Germany.

\subsubsection{Upper Rhaetic}

The Upper Rhaetic contains a microflora similar to that of the Middle Rhaetic but poorer. Rhaetipollis germanicus is absent except for rare occurrence in the basal part. The main part of the Upper Rhaetic in the DDR hence belongs to the Ricciisporites Polypodiisporites Zone.

\subsubsection{Lias alfa}

The Rhaetic Liassic boundary in the DDR is marked by Pinuspollenites minimus (Couper) Kemp. (al. Pityosporites scaurus, (Nils.) E. Schulz), Trachysporites fuscus Nils. (al. Converrucosisporites luebbenensis E. Schulz), Heliosporites altmarkensis. E. Schulz and by Quadraeculina anellaeformis Mal. all of which are more common in the Liassic than in the Rhaetic. Therefore the quantitative changes of the Rhaetic Liassic boundary in the DDR equal those in the NW German Basin. Further the Liassic is characterized by the appearance of Lycopodiumsporites semimuris Danze-Corsin \& Laveine (al. Retitriletes globosus Pierce), Aratrisporites minimus E. Schulz, Clavatipollenites hughesi Couper and of Cerebropollenites thiergarti $\mathrm{E}$. Schulz. Through the appearance of the mentioned species the Rhaetic Liassic boundary is more sharp in the DDR than in the investigated profiles (Table 1-4), where these species appear at several levels. The sharp boundary in the DDR is possibly due to the generalized way in which the succession of microfloras is presented on Schulz's schemes.

In the lowermost Liassic (Lias alfa 1) a number of Rhaetic species are still present and Cerebropollenites macroverrucosus (Thierg.) E. Schulz is absent. The last-mentioned species is probably absent in Lias alfa 2, but present 


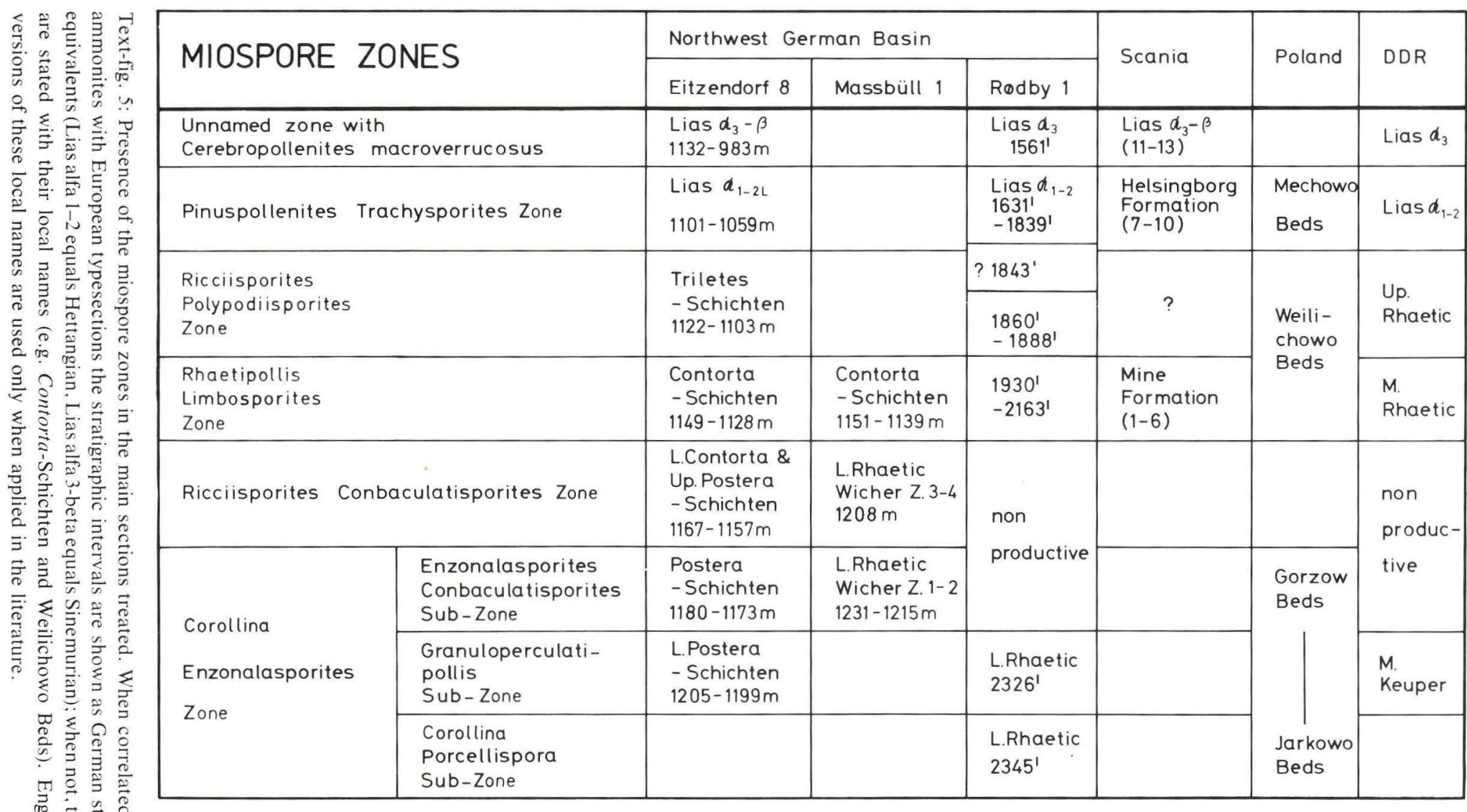

NUMBERS IN BRACKETS REFER TO SAMPLES NOS. 
in Lias alfa 3 (Schulz \& Mai 1966) so that Lias alfa 1 in DDR belongs to the Pinuspollenites Trachysporites Zone and Lias alfa 3 to the superimposed unnamed zone with Cerebropollenites macroverrucosus. The boundary between Lias alfa 2 and 3 (Hettangian Sinemurian boundary) is to some degree also characterized by the disappearance of Ricciisporites, Cingulizonates rhaeticus (Reinh.) E. Schulz and Trachysporites fuscus Nilsson (al. Converrucosisporites luebbensis) which, however, often are too rare to be useful (E. Schulz \& Mai 1967). As some of the species, which disappear at the boundary under discussion, have been noted higher in the Liassic the disappearance of species at the Lias 2-3 boundary is partly due to facies change (Schulz \& Mai 1966).

\section{Age of the miospore zones and correlation of the Rhaetic to} Lower Liassic within the onshore south-eastern North Sea Basin

Comparing the occurrence of miospore zones in the individual areas discussed in passage 6 to 12 , the Rhaetic to Lower Liassic sections in the onshore south-eastern North Sea Basin have to be correlated as shown on text-fig. 5.

The "M Keuper" noted on text-fig. 5 from DDR in the Granuloperculatipollis Subzone conflicts with the Lower Rhaetic age of this subzone in Eitzendorf 8 and Rødby 1. The "M Keuper'" refers to "'oberen Mittelkeuper (speziell oberer Steinmergelkeuper)" in E. Schulz (1967 p. 551) dated on lithologic and geophysical data (absence of sand ?, compare passage 12.1). It should be noted that E. Schulz stated the range of Granuloperculatipollis rudis Venkatachala \& Goczan 1964 established on Lower Rhaetic material from Hungary as “"? Oberer Mittelkeuper bis Unterrhät”' (E. Schulz 1967 p. 605). Doing so he doubted the Middle Keuper age. Due to this and the absence of the Granuloperculatipollis Subzone microflora in the basal Lower Rhaetic in Rødby 1, I consider the "M Keuper"' age in the DDR to be wrong and probably caused by a locally smaller influx of sand.

From the data given above and in passage 6 to 12 it is evident that the miospore zones defined in this paper have the following stratigraphical extension in the onshore south-eastern North Sea Basin:

Unnamed zone with

Cerebropollenites macroverrucosus:

The Pinuspollenites Trachysporites Z.:

The Ricciisporites Polypodiisporites Z.:

The Rhaetipollis Limbosporites Z.:
Lias alfa 3-beta - ?

Lias alfa 1-2

Upper Rhaetic

Middle Rhaetic 
The Corollina Enzonalasporites Z.:

Norian-Lower Rhaetic

The Enzonalasporites Conbaculatisporites Sub-Z.: Lower Rhaetic

The Granuloperculatipollis Sub-Z.:

Lower Rhaetic

The Corollina Porcellispora Sub-Z.:

Norian-Lower Rhaetic

\section{Palynological preparation}

For each preparation about 1 gram of clayey sediment is used. The lump of clay is cleaned with a knife and the surface is washed and dryed with a cleenex prior to crushing. Then the sample is treated with the following chemicals:

$10 \% \mathrm{HCl}$ ( 5 minutes - 24 hours)

$10 \% \mathrm{KOH}(10$ minutes)

concentrated $\mathrm{HF}$ (cold 2-5 days)

$10 \% \mathrm{HCl}$ (boiling, 20 minutes)

Schulzes Solution (10-40 minutes)

$0,5 \% \mathrm{KOH}$ ( 5 minutes)

$3 \times \mathrm{H}_{2} / \mathrm{O}$

$2 \times$ Bensene

Silicone oil

Oxidation with Schulzes Solution may cause destruction of the miospores and it is important to use the shortest time necessary oxidation time is reached when foam (like on a porter) appears when shaking it in $\mathrm{KOH}$. The liquid then remains dark brown after centrifugation.

The Rødby material is exclusively embedded in silicone oil. Most of the other samples are embedded in glycerine after the $3 \times \mathrm{H}_{2} \mathrm{O}$.

\section{Key to the stratigraphic tables, photographic plates and systematic part}

In the systematic part each species has a definite number. This number is found in brackets behind the name of the species, when notes on the stratigraphic tables (Tables I-IV) or the photographic plates.

On each stratigraphic table (Table I-IV) the species are arranged and numbered after their first occurrence. In the systematical part these numbers are referred to under each species. 
Using these two types of numbers it should be possible with a minimum of time to find a certain species in the systematical part on the photographic plates and the stratigraphical tables.

\section{Explanation to the stratigraphic tables}

Information on the dating of the samples was given in the regional chapters.

$\mathrm{D}$ means that the type under consideration is dominant (estimated not counted), $\times$ means that the type is present, + that 2 or more specimens have been found and - that only one specimen has been found.

On table 30.3 means that one or more specimens have been found outside the counting in which one specimen occurred.

On table $4 \mathrm{n}$ and $\mathrm{N}$ indicates that Nilsson (1958) noted the taxa in slides not investigated by me. $\mathrm{N}$ is used when he figured the taxa and $\mathrm{n}$ when he noted it only. 


\section{Systematics, mainly based on the Rødby 1 material}

\subsection{Introduction}

Except for the well illustrated British and East German species described by Couper (1958) and E. Schulz (1967 etc.), respectively, most determinations are based on restudy of the type material. The restudies were mainly carried out at the institutions where the respective types are deposited. It is worth to notice that the microscopes available at these institutions were often better than those used by the original authors. Restudied specimens referred to are marked with an asterisk $\left(^{*}\right)$.

\subsection{Microspores}

\subsubsection{Trilete smooth microspores}

\section{Deltoidospora Miner 1935}

$D$. covers smooth triangular trilete microspores with long sutures and more or less thickened contactareas, with or without folds along the trilete-mark. The contactarea-thickenings are situated more proximal than the equatorial thickenings in Gleicheniidites Ross 1949.

Microspores of Deltoidospora type are in older literature placed in a number of genera (Leiotriletes Naumova 1939, Concavisporites Pflug 1953, Cyathidites Couper 1953, Dictyophyllidites Couper 1958, etc.) but are in newer literature (Briche et al. 1963, Pocock 1970, Cornet \& Traverse 1975, etc.) often placed in Deltoidospora. This new approach is followed here.

1. Deltoidospora toralis Leschik 1955, species n. comb.

P1. 1 fig. $2 \&$ 3. Tables I/19, II/15, III/51 \& IV/16.

1955 Laevigatosporites toralis Leschik p. 12, pl. 1, fig. 9.*

D. toralis comprises smooth triangular microspores with thickened contactareas and long sutures (ca. $4 / 5$ r). In undeformed specimens (D. toralis, pl. 1 fig. $2 \& 3$ ) the sutures are narrow and covered by an elevated membrane and the exine is infolded between the "equator"' (amb) and the thickened contactarea exine. In some deformed specimens (D. toralis var. media, pl. 1, 
fig. 1) the proximal hemisphere is flattened and each of the sutures is broadened to a bright leaf-like area, surrounded by the darker thickened contactarea exine. A few intermediate specimens with only one or two deformed sutures are present. Therefore media is placed as a variety within toralis.

D. toralis is known in the literature under a variety of names: Leiotriletes parvus Nilsson, L. mortoni De Jersey, Paraconcavisporites lunzensis Klaus, Deltoidosporites neddeni Potonié emend. Danze-Corsin \& Laveine, etc. Dictyophyllidites harrisi Couper differs from $D$. toralis by the absence of tori as noted by Klaus (1960 p. 122).

1 b. Deltoidospora toralis (Leschik) var. media Nilsson 1958, n. comb. \& r. Pl. 1 fig. 1. Tables I/49, II/16, III/52 \& IV/7.

1958 Leiotriletes medius Nilsson p. 31, pl. 1, fig. 2-4.

For remarks see also under $D$. toralis.

D. toralis var. media resembles Leiotriletes mesozoicus (Thiergart 1949) E. Schulz 1967 but are distinguished by the longer sutures. Two specimens referred to the latter species were noted in Rødby 1 (spl. 1843' \& 1631') but are not included on the plates or tables.

D. toralis var. media is probably identical with the Harrisispora species used by Pocock 1970.

2. Deltoidospora minor (Couper 1953) Pocock 1970

Pl. 1 fig. 6. Tables I/68 \& III/25.

D. minor differs from $D$. toralis by absence of an elevated membrane covering the narrow sutures and by absence of thickened contractareas.

Leiotriletes (al. Laevigatosporites) tenuis (Leschik 1956) Bharadwaj \& Singh 1964 is a junior synonym of $D$. minor.

3. Deltoidospora auritora Reinhardt 1961, species n. comb.

Pl. 1 fig. 5. Tables I/15, III/104 \& IV/62.

1961 Toroisporis auritorus Reinhardt, p. 706, pl. 1 fig. 2-3.*

$D$. auritora resembles $D$. toralis but the thickened exine of the contractareas continues around the apices.

Stratum typicum with sample no. 54 of Reinhardt (1961 p. 706, 1964 p. 50) is probably the lower part of Schäfers "rhätischen Mergel" which by Putzer (1938 p. 331) was referred to Lias alfa 1.

Presence of $D$. autora seems to be indicative of Upper Rhaetic through Lias alfa. 
4. Deltoidospora crassexina Nilsson 1958, species n. comb.

Pl. 1 fig. 4, pl. 12, fig. 8 (new photos of holotype). Tables I/69, III/53 \& IV/17.

1958 Concavisporites crassexinus Nilsson, p. 35, pl. 1, fig. 11.*

1964 Toroisporis crassexinus (Nilsson). Reinhardt, p. 49, pl. 1 fig. 5 \& 9-11.

1967 Gleicheniidites (Triremisporites) umbonatus (Bolchovitina) E. Schulz, p. 556, pl. 1 fig. 3-4.

non

1953 Gleichenia umbonata Bolkhovitina (CFSP 8-73).

$D$. crassexina resembles D. toralis, but differs by having three extra exine thickenings located semidistal between the apices. These thickenings are isolated from the contactarea thickenings by infolded thinner "equatorial" exine. By presence of three contactarea thickenings plus three semidistal thickenings $D$. crassexina differs from Gleicheniidites with only three thickenings present, lying exactly at the equator (i.e. in the same plant as the apices).

D. crassexina occurs from the Middle Rhaetic to at least the Wealden. Similar types are also present in the Paleocene (Krutzsch 1959 pl. 10 fig. 75-76). The acme falls in the (Lower) Liassic, however.

5. Deltoidospora sp.

Pl. 1 fig. 7a \& b. Table III/109.

This species has a (serrated) triangular outline of the contactareas. The sutures are undulating and look abnormally dark at high focus. Possibly this type represents abortive microspores. It is rare and noted separately only due to its restricted stratigraphic occurrence (topmost Upper Rhaetic through Lias alfa 2).

\section{Intrapunctisporis Krutzsch 1959}

Intrapunctisporis is characterized by a scabrate sculpture at the inside of the exine while the outer surface is smooth. The distinction from Deltoidospora is somewhat doubtful as a faintly developed scabrate sculpture might also be developed at the inner side of the exine in the last mentioned genus. It may not be totally rules out, that this dissimilarity is due to different preservation.

6. Intrapunctisporis toralis Leschik 1955, species n. comb.

Pl. 1 fig. 8. Tables I/67, III/54 \& IV/27.

1955 Punctatisporites toralis Leschik p. 19, pl. 2 fig. 11.*

4. D.G.U. II. rk. nr. 109 
I. Toralis resembles Deltoidospora toralis, but has a distinct scabrate sculpture on the inside of the exine.

Only known from the Carnian and Middle Rhaetic through Lias alfa.

7. Intrapunctisporis hians Leschik 1955, species n. comb.

Pl. 1 fig. 9. Table $\mathrm{I} / 106$.

1955 Punctatisporites hians Leschik p. 20, pl. 2 fig. 13.*

I. hians is somewhat similar to Deltoidospora crassexinus, but has a scabrate sculpture on the inside of the exine, and an extremely thin exine between the contractarea - and semidistal thickenings. Of the latter, one, two or all three may be missing.

Punctatisporites (Ibrahim 1933) Pot. \& Kremp 1954

Punctatisporites is characterized by a nearly circular amb and long sutures. The exine is smooth at the surface but may be scabrate at the inside.

Todisporites have often been used to classify microspores of this type in Mesozoic deposits while Punctatisporites has been used on Palaeozoic material. But as the holotypes of Todisporites (T. major Couper 1958 pl. 16 fig. 6) and of Punctatisporites (P. punctatus new phot. Pot. \& Kremp 1955 pl. 11 fig. 122) are closely similar, the proposal of Kedves and Simoncsics (1964) to use Punctatisporites also on Mesozoic material is followed here. It is worth noticing that also Hope \& G. Schulz (1973) used Punctatisporites at Mesozoic material.

8. Punctatisporites major (Couper 1958) Kedves \& Simoncsics 1964

Pl. 1 fig. 10. Tables $\mathrm{I} / 16, \mathrm{II} / 38, \mathrm{III} / 26$ \& IV/9.

This species is commonly placed in Todisporites and known as T. major Couper.

9. Punctatisporites globosus Leschik 1955, species n. comb.

Pl. 1 fig. 11. Tables $\mathrm{I} / 97$ \& III/27.

1955 Laevigatisporites globosus Leschik p. 11, pl. 1 fig. 5.*

$P$. globosus is a senior synonym of the wellknown Todisporites minor Couper 1958.

10. "Todisporites" cf. cinctus (Maljavkina 1964) Orlowska-Zwolinska 1971 Pl. 1 fig. 12. Table III/21. 
Retusotriletes Naumova 1953

11. Retusotriletes mesozoicus Klaus 1960

Pl. 1 fig. 13. Table III/72.

$R$. mesozoicus differs from Punctatisporites major mainly by the presence of curvaeturae imperfectae.

$R$. mesozoicus is mainly an Upper Triassic species and is not known above Lias alfa 2 .

Calamospora Schopf, Wilson \& Bentall 1944

12. Calamospora tener (Leschik 1955) Mädler 1964

Pl. 1 fig. 14. Tables I/92, III/28 \& IV/8.

Mädler (1964b p. 92) gave a thorough discussion of this species which is a senior synonym of $C$. mesozoica Couper 1958.

\subsubsection{Spagnoide microspores}

Stereisporites Thomson \& Pflug 1953 sensu Döring et al. 1966

Stereisporites is used here in the broad sence by Döring et al. 1966 to encompas spagnoide microspores (small "rigid" rounded triangular) both smooth and with a number of complex features like distal ringthickenings etc.

13. Stereisporites stereoides (Potonie \& Vernitz 1934) Thomson \& Pflug 1953

Pl. 2 fig. 1. Tables I/84, II/10, III/55 \& IV/30.

S. stereoides is smooth and the most simple of the $S$. species encountered here.

Laevigatosporites scissus Leschik (1955 p. 13, pl. 1 fig. $\left.22^{*}\right)$ is probably a junior synonym of $S$. stereoides.

14. Stereisporites antiquatisporis (Wilson \& Webster 1946) Dettmann 1963 Tables I/85, III/107 \& IV/61.

As S. stereoides but with a distal bos.

15. Stereisporites punctus (Klaus 1960) Krutzsch 1963

P1. 2 fig. 2 \& 3. Tables I/76, II/34, III/49 \& IV/57.

As $S$. stereoides but with a distal ring thickening and faint distal radial grooves. 
16. Stereisporites cicatricosus (Rogalska 1954) E. Schulz 1967

Pl. 2 fig. 4. Tables I/64, III/103 \& III/52.

Characterized by distal grooves near the equator. No distal ring thickening or with a faint ring and distal bos.

17. Stereisporites cf. lunaris Rogalska 1954, species n. comb.

Pl. 2 fig. 5. Tables II/42 \& III/47.

1954 Sporites lunaris Rogalska p. 45, pl. 12, fig. 9.*

Characterized by a sharply deliminated polar thinning.

Nevesisporites Jersey \& Paten 1964

18. Nevesisporites limatulus Playford 1965

Pl. 2 fig. 3. Table I/103.

This nearly spagnoide microsporespecies is mainly characterized by a distal subequatorial ringthinning ("rimula") and low granules (at the contactareas ?).

Probably identical microspores are known as Classopollenites tripartitus Levet-Carette (in Rioult \& Levet-Carette 1965 p. 294) and N. lubricatus Orlowska-Zwolinska (1972 p. 309).

The present occurrence in the Lias alfa 3 of Eitzendorf and Munkerup as well as in the Lower Sinemurian in Luxembourg (Hiltmann 1967, p. 160, pl. 2 fig. 9 "Verrucose Spore inc. sed. sp. B") are the youngest known reports of this mainly Triassic species.

\subsubsection{Ornamented microspores}

Foraminisporis Krutzsch 1959

19. Foraminisporis jurassicus E. Schulz 1967

Pl. 2 fig. 6. Tables $\mathrm{I} / 100$ \& III/115.

\section{Trachysporites Nilsson 1958}

Trachysporites is characterized by a mixed ornamentation with several types of sculptural elements (rugulae, granulae, coni, etc.) at each specimen (Nilsson 1958 p. 38). T. differs from Conbaculatisporites by having lower sculptural elements and from Baculatisporites by having a more triangular amb. Lunzisporites Bharadwaj \& Singh (1964 p. 32) is a junior synonym of $T$. 
20. Trachysporites fuscus Nilsson 1958

Pl. 2 fig. 7, pl. 12 fig. 9. Tables I/40, II/39, III/111 \& IV/54.

T. fuscus is distinguished by a dense sculpture of granulae and coni partly fused to an irregular reticulum.

T. tuberosus Nilsson (1958 p. 39, pl. 2 fig. 2*), Conbaculatisporites densus Mädler (1964a, p. 175, pl. 1 fig. 9*), Converrucosisporites luebbensis E. Schulz (1967 p. 561 pl. 2, fig. 15-17), Triletisporites pseudoreticulosus Hiltmann (1967 p. 160, pl. 3 fig. 1-2) and probably also Lunzisporites lunaris Bharadwaj \& Singh (1964 p. 32, pl. 2 fig. 41-42) fall within the variation of $T$. fuscus and are hence considered to be junior synonyms of this species.

T. tuberosus ranges topmost L. Rhaetic to Lias alfa 3 and is, when found in a Liassic microflora (with many Pinuspollenites Chasmatosporites etc.) a good indicator of Lias alfa in the investigated area. It is practically absent in the Middle to Upper Rhaetic.

\section{Trachysporites asper Nilsson 1958}

Pl. 2 fig. 8. Tables I/41, II/36, III/56 \& IV/64.

T. asper is distinguished by a faint and dispersed sculpture of microconi united by indistinct lower crests forming an irregular (micro)reticulum.

Cyathidites sabuli Reinhardt (1961 p. 704, pl. 1 fig. $\left.6^{\star} \& 7^{\star}\right)$ is a junior synonym of $T$. asper Nilsson (1958 p. 39, pl. 2 fig. $3^{*}$ ).

T. asper ranges Lower Rhaetic to Lias alfa 3. Opposite to T. fuscus it is also found in the Middle and especially in the Upper Rhaetic.

22. Trachysporites cf. sparsus Bharadwaj \& Singh 1964, species n. comb. Pl. 2 fig. 9. Tables I/17, II/11 \& III/50.

1964 Lunzisporites sparsus Bharadwaj \& Singh p. 33, pl. 2 fig. 45.

T. cf. sparsus is characterized by a sculpture of disperse granules partly connected by lower crests froming an irregular reticulum.

The distribution of $T$. cf. sparsus equals that of $T$. fuscus with the difference that $T$. cf. sparsus is not known above Lias alfa 2 and has its main occurrence in the Lower Rhaetic, tentatively.

\section{Conbaculatisporites Klaus 1960}

23. Conbaculatisporites mesozoicus Klaus 1960.

Pl. 2 fig. 10. Tables I/50, II/43, III/57 \& IV/31.

For remarks see also under $C$. spinosus.

The stratigraphical distribution of $C$. mesozoicus is of prime note. It is 
regularly present in the Lower-Middle Rhaetic junction, nearby absent in most of the Middle and Upper Rhaetic and regularly present in the Lias alfa in the investigated area.

24. Conbaculatisporites spinosus Mädler 1964, species n.comb. Pl. 2 fig. 11. Tables I/51, II/58 \& IV/32.

1964 Anemiidites spinosus Mädler 1964a, p. 180, pl, 2 fig. 11*.

Similar to C. mesozoicus the sculpture consists of coni spinae and baculae which are more or less confluent at their bases forming a low indistinct reticulum (also present at the holotype of C. mesozoicus Klaus 1960, pl. 29, fig. $\left.15^{\star}\right)$. However, C. spinosus is tentatively kept separate from $C$. mesozoicus by its relatively longer polar axis, smaller size and often more indistinct "basal reticulum".

Conbaculatisporites and not Anemiidites Ross 1949 is used here as I consider the sculpture of $A$. doubtful (Ross 1948, p. 32: spines with "wiederhaken").

Anemiidites echinatus Ross in Orbell (1973, pl. 3 fig. 4) is intermediate between $C$. mesozoicus and $C$. spinosus as used here.

Baculatisporites Thomson \& Pflug (March 1953) sensu Krutzsch 1967.

Krutzsch considered the sculpture of $B$. to vary "von schwach \pm echinatoiden Einzel-Baculae bis zu flach-rugulaten, geschlängelten Muri und Warzen". He united Rugulati-sporites Thomsen \& Pflug with B. and considered Osmundacidites Couper 1953 to be a junior synonym of $B$. (Krutzsch 1967, p. 6, etc.).

25. Baculatisporites comaumensis (Cookson 1953) Potonie 1956. Pl. 2 fig. 12. Tables I/52, III/59 \& IV/53.

In the S.E.M. and also by careful examination in the light microscope it is seen that the sculpture consists of coni and baculae some of which are swollen and confluent at their tips forming "gemmulae" with two necks.

26. Baculatisporites wellmani (Couper 1953) Krutzsch 1959

Pl. 2 fig. 13. Tables I/59, III/73 \& IV/25.

$B$. wellmani is distinguished from $B$. comaumensis by lower, denser and more confluent sculptural elements, but intermediate specimens are present in the investigated material. 
27. Baculatisporites opressus Leschik 1955, species n.comb.

P1. 2 fig. 15a-b. Table III/38.

1955. Cyclogranisporites opressus Leschik p. 16, pl. 1 fig. 23.

Characteristic of this small species is the faintly triangular amb and "margo ridges" of upfolded normal sculptured exine. The sculpture consists of micro-baculae, - gemmulae and - coni.

Apiculatisporis Potonie \& Kremp 1956

28. Apiculatisporis ovalis (Nilsson 1958) Norris 1965

Pl. 2 fig. 14. Tables I/45, III/60 \& IV/10.

A. ovalis is distinguished from $B$. comaumensis by a predominantly conate sculpture. A few baculae may be present but never united at their tips.

29. Apiculatisporis parvispinosus (Leschik 1955) E. Schulz 1962.

Pl. 2 fig. 16. Tables I/39, III/24 \& IV/28.

Especially characteristic of this small conate species is the mixed triletemonolete aperture.

A. parvispinosus is a common element in many Upper Rhaetic microfloras but ranges from the Carnian to the basal Lias alfa.

Porcellispora Scheuring 1970.

30. Porcellispora longdonensis (Clarke 1965) Scheuring 1970.

Pl. 3 fig. 1a-b. Tables II/12 \& III/1.

In the present material $P$. longdonensis is azonate and has high distal (bottle-shaped) spines. It is well differentiated from the zonate Naiaditaspora harrisi Orbel 1973, with much lower distal sculptural elements. However, these forms are rare and it is possible that intermediate forms will be found by future investigations in northern Europe as they have been in the Alpine area (Morebey 1975, p. 23).

$P$. longdonensis, which is a common component in many European Carnian and Norian microfloras, ranges in the present material to the basal Lower Rhaetic (? = Upper Norian).

Anapiculatisporites Potonie \& Kremp 1955.

31. Anapiculatisporites spiniger (Leschik 1955) Reinhardt 1961.

Pl. 3 fig. 2. Tables I/14, III/13 and IV/72.

A. spiniger is tentatively distinguished from A. telephorus by stronger developed spines. 
32. Anapiculatisporites telephorus (Pautsch 1958) Klaus 1960.

Pl. 3 fig. 3. Tables I/37, II/44, III/18.

M. Pautsch investigated the specimen shown on pl. 3. fig. 3 and confirmed the determination (personel communication).

Verrucosisporites (Ibr. 1933) Smith 1971.

33. Verrucosisporites klukiformis Nilsson 1958, species n.comb.

Pl. 3 fig. 4. Tabl. III/74 \& IV/34.

1958 Corrugatisporites klukiformis Nilsson p. 44, Pl. 2 fig. 18.

$V$. klukiformis is placed in Verrucosisporites, and not maintained in the more reticulate genus Convolutispora Staplin \& Malloy 1955 as the sculpture at klukiformis are not more reticulate than at species referred to Verrucosisporites by Smith (1971 pl. 15 fig. 1-6, etc.).

34. Verrucosisporites sp.

Pl. 3 fig. 5. Tables I/61 \& III/82.

Polypodiisporites Potonie \& Gelltich ex Potonie 1956.

Playford and Dettman discussed this genus (1965 p. 150). Balme did also places types with a mixed monolete-trilete aperture in $P$. (1970 p. 346-347).

35. Polypodiisporites polymicroforatus Orl.-Zwol. 1966, species n.comb. Pl. 3 fig. 6a-b. Tables I/65, III/61 \& IV/44.

1966 Foveosporites polymicroforatus Orlowska-Zwolinska p. 1011 pl. 2 fig. $15-16$ \& pl. 3 fig. $19^{*}-21^{*}$.

The widely used Convolutispora microrugulata and C. microfoveolata both erected by E. Schulz 1967 are junior synonyms of $P$. polymicroforatus.

$P$. polymicroforatus is a stratigraphically very important species, which ranges from Middle Rhaetic to Lias alfa 3. with acme in the (Middle to) Upper Rhaetic.

Presence of related forms in older deposits ( $P$. mutabilis Balme 1970, Upper Permian W. Pakistan) suggests that $P$. polymicroforatus in the future will be found also in pre Middle Rhaetic deposits (outside Europe).

36. Polypodiisporites ipsviensis (de Jersey 1962) Playford \& Dettmann 1965 Pl. 3 fig. 7. Tables I/58 \& III/48.

$P$. polymicroforatus and $P$. ipsviensis are connected by intermediate forms in the present material. However, each type occurs alone in its respective 
type material (Poland and Australia). They are tentatively kept separate here.

Cyclogranisporites Potoni \& Kremp 1954

37. Cyclogranisporites arenosus Mädler 1964

Pl. 3 fig. 8. Table III/62.

Lycopodiumsporites (Thiergart 1938) Delcourt \& Sprumont 1955

38. Lycopodiumsporites austroclavatidites (Cookson 1953), Potonie 1957

Pl. 3 fig. 10. Tables I/104, II/45, III/75 \& IV/18.

Reticulate with polygonal lumina which are $2-5 \times 3-10$ microns in size.

The present record of a single specimen from the topmost Lower Rhaetic in Massbüll 1 is the oldest occurrence of this species, well-known from literature in Middle Rhaetic through Tertiary deposits.

39. Lycopodiumsporites semimuris Danze-Corsin \& Laveine 1963

Pl. 3 fig. 11. Tables I/105, III/119 \& IV/70.

L. semimuris is characterized by a reduced reticulum with some missing muri.

Regular presence of L. semimuris characterizes the Lias alfa $3 \&$ beta in the present material, although some doubtful specimens are also present close to the Rhaetic Liassic boundary.

Ischyosporites Balme 1957

40. Ischyosporites sp. af. I. crateris Balme 1957

Pl. 3 fig. 9. Tables III/ $108 \&$ IV/37.

Most specimens differ from "Middle Jurassic"' Klukisporites/Ischyosporites by having clearly convex sides, however, a few have faintly concave sides.

\section{Iraquispora Singh 1964}

Iraquispora Singh (July 1964) is considered to be a senior synonym of Kyrtomisporites Mädler (Dec. 1964) as the respective holotypes (I. labrata Singh 1964, p. 243 \& K. laevigatus Mädler 1964a, p. 188) are closely similar. The species placed in $K$. by Mädler are therefore referred to Iraquispora below.

41. Iraquispora laevigata Mädler 1964, species n.comb.

Pl. 3 fig. 12. Table III/102. 
1964 Kyrtomisporites laevigatus Mädler 1964a, p. 188, pl. 3 fig. $4^{*}$.

1964 Cingulizonates rhaeticus Mädler 1964a, p. 176, pl. 1 fig. 11*.

Sporites magnus Rogalska (1956 p. 85, pl. 30 fig. $1^{*}$ ) resembles I. laevigatus but has a thicker cingulum. When the variation of $S$. magnus becomes better known it may show up to be a senior synonym of I. laevigatus.

42. Iraquispora speciosa Mädler 1964, species n.comb.

Pl. 3 fig. 13. Tables I/66 \& III/91.

1964 Kyrtomisporites speciosus Mädler 1964a, p. 188, pl. 3 fig. $5^{*}-7^{*}$.

\section{Uvaesporites Döring 1965}

43. Species Uvaesporites reissingeri Reinhardt 1961, species n.comb.

Pl. 3 fig. 14. Tables I/53, II/17 \& III/76.

1961 Triletes reissingeri Reinhardt p. 707 pl. 2 fig. $1^{*}-2^{*}$.

This species is generally known as Uvaesporites argentiformis (Bolch.) Eb. Schulz 1967 (see Orbell 1973, Herngreen \& de Boer 1974, Morbey 1975, etc.). $U$. argaentiformis is not used here as the figure of its holotype (drawing only, see CFSP 8-67) does not allow a safe comparison.

In the Polish literature this species is also known as Ophioglossaceae or Botrychium lunaria (Rogalska 1954, etc.).

44. Tetrads of Uvaesporites sp.

Pl. 3 fig. 15. Tables I/106 \& III/120.

The distal area on each of the four (trilete) triangular microspores united in the tetrad might be thinned causing some similarity with Ricciisporites tuberculatus. However, by the latter each of the four pollen united in the tetrad has a more elongate distal "monosulcate" thinning. I consider the similarity as a convergent evolution, where the thinning of the distal areas allows changes in volumen by changing humidity (harmomegathy sensu Wodehouse 1935).

In the investigated wells this species is restricted to the Lias alfa 3 to beta. It is also present (less than $1 \%$ ) in the probably Sinemurian Munkerup Clay. In Holland it reaches its acme (less than $1 \%$ ) in the Upper Sinemurian (Herngreen \& de Boer 1974 al. Circularesporites cerebroides Danze \& Cor$\sin 1963)$.

45. Species Uvaesporites cf. sanguilentiformis Sachanova \& Iljina 1968, species n. comb.

Pl. 4 fig. 1. Tables $\mathrm{I} / 56$ \& III/121. 
As Selinginella is a recent genus, sanguinolentiformis is combined with the formgenus Uvaesporites. It should be noted that Iljina considered the species to be closely similar to Uvaesporites argentiformis (Bolch.) E. Schulz (Iljina 1971 p. 44).

Contignisporites Dettmann 1963

46. Contignisporites problematicus (Couper 1958) Döring 1965

Pl. 4 fig. 2. Tables I/38, II/46, III/63 \& Iv/63.

Neochomotriletes Reinhardt 1961

47. Neochomotriletes triangularis (Bolch. 1956) Reinhardt 1961

P1. 4 fig. 3. Tables I/77, III/110 \& IV/49.

Lycospora

48. Lycospora sp.

Pl. 4 fig. 4. Tables III/77 \& IV/11.

Probably this type is redeposited from Carboniferous strata. Similar types are known in the Rhaetic and Jurassic as Cingulatisporites scabratus Couper 1958, Aequitriradites salebrosaceous (Mal. 1947) Nilsson 1958 and Thiergartisporites deltoides Mädler 1964.

Densosporites (Berry) Potonie \& Kremp 1954

E. Schulz (1967 p. 582) stated the reasons for the incorporation of Cingulatizonites Mädler 1964 in Densosporites.

49. Densosporites fissus (Reinhardt 1964) E. Schulz 1967

Pl. 4 fig. 5. Tables I/81, III/43 \& IV/3.

Regular presence of D. fissus is characteristic of the Middle to Upper Rhaetic.

50. Densosporites cavernatus Orlowska-Zwolinska 1966

Pl. 4 fig. 6. Tables III/83 \& IV/38.

The widely used name D. foveocingulatus E. Schulz 1967 is a junior synonym of $D$. cavernatus.

Limbosporites lundbladi specimens with weakley developed distal sculpture (e.g. Orbell $1973 \mathrm{pl} .4$ fig. 5) may easily be mistaken for $D$. cavernatus . 
However, D. cavernatus has perforations through the zona, whereas Limbosporites has grooves immediately distal of the zona infolded towards the center of the spore.

Typical Densosporites cavernatus is only known from the Middle and Upper Rhaetic.

51. Densosporites irregularis Hacq. \& Barss 1957

Pl. 4 fig. 7. Tables III/116.

This Carboniverous species was used by E. Schulz (1967 p. 583) to classify Liassic material.

52. Densosporites cf. cerebralis Mädler 1964, species n. comb.

Pl. 4 fig. 8 \& 9. Tables I/62, II/49 \& III/44.

1964 Trizonites cerebralis Mädler 1964a p. 185. Pl. 3 fig. 1*.

This species resembles $D$. fissus but the distal surface is upfolded into irregular rugulae. This similarity warrants a placing in the same genus i.e. in Densosporites.

The specimens in the investigated material lack the prominent apices present at the holotype. However, specimens similar to mine have been placed in this species by Hope \& G. Schulz (1973 pl. 20 fig. 5).

In Europe this species is only known from the Middle and Upper Rhaetic.

Cingulizonates Dybova \& Jachowicz 1957

In the present material Cingulizonates differs from Densosporites by displaying both a zona and a cingulum. The distinction is not sharp, however, C. differs from Krauselisporites (Leschik 1955) Scheuring 1974 by the absence of distal sculpture. As noted by E. Schulz (1967, p. 584) Anulatisporites Mädler 1964 cannot be kept separate from Cingulizonates.

53. Cingulizonates rhaeticus (Reinhardt 1961) E. Schulz 1967

Pl. 4 fig. 10. Tables I/60, III/78 \& IV/4.

This important species is also known in the literature as "Simplicisporites granulosus Leschik" (Nilsson 1958, p. 77 pl. 7 fig. 10*), Anulatisporites drawehni Mädler (1964a p. 177, pl. 2 fig. $1^{*}-2^{*}$ ) and Cingulizonates delicatus Orlowska-Zwolinska (1966 p. 1014 pl. 7 fig. 36-38*). Possibly this species should be attributed to Thiergart, who considers that the grain shown here on plate 4 fig. 10, belongs to the same "Formkreis" as his Sporites rhaeticus 
Thiergart 1949 (Thiergart personal communication). Because E. Schulz who has reinvestigate some of Thiergarts material (E. Schulz 1967, p. 603), attributes this species to Reinhard and not to Thiergart, $C$. rhaeticus is tentatively attributed to Reinhard whose illustration (1961, pl. 2 fig. $\left.3^{\star}\right)$ allow a safe identification.

C. rhaeticus differs from Thomsonisporites punctatus Leschik (1955 p. 39 , pl. 5 fig. $6^{\star}$ ) by having thinner exine proximally and from some variants of Densoisporites poatinaensis Playford (1965 pl. 9 fig. 15) and Lundbladispora obsolata Balme (1970 pl. 5 fig. 11) by having a more massive distal exine which is only spongious at the inner side.

C. rhaeticus is a stratigraphically wery important species which occurs regularly in the Middle and Upper Rhaetic and sporadically in the Lias alfa of the investigated area (text fig. 4) and DDR (E. Schulz 1967). C. rhaeticus is also known from the Middle to (Upper) Rhaetic Weilichowo beds in Poland (Orlowska-Zwolinska 1967) and Middle and basal Upper Rhaetic of Britain (Fischer 1972).

54. Species Cingulizonates marginatus Mädler 1964, species n. comb. Pl. 4, fig. 11. Tables I/89 \& III/98.

1964 Cingulatizonites marginatus Mädler 1964a, p. 190 pl. 3 fig. 10*

C. marginatus is identical with Densosporites cingulatus Eb. Schulz 1967.

55. Cingulizonates cf. inaequalis Mädler 1964, species n. comb.

Pl. 5 fig. 1. Tables I/86, III/97 \& IV/39.

1964 Aequitriradites inaequalis Mädler 1964a p. 191, pl. 3 fig. 11.

$C$. "cf. inaequalis differs from C. marginatus by a distal constriction between the zone and the "cingulum", which may be describes as a semidistal ring. Probably $C$. cf. inaequalis should be refered to the Carboniferous species $C$. tuberosus Dyb. \& Jach. (1957 pl. 53 fig. 1-4), as done by Orlowska-Zwolinska (1966). However, the Rhaetic species $C$. cf. inaequalis is used here mainly of stratigraphic reasons.

C. cf. inaequalis has its acme in the Upper Rhaetic. It is also present in the Middle(?) Rhaetic and Lias alfa 3 of Scania.

Limbosporites Nilsson 1958

56. Limbosporites lundbladi Nilsson 1958

Pl. 5 fig. 2 \& 3. Tables $\mathrm{I} / 63, \mathrm{II} / 50, \mathrm{III} / 46$ \& IV/5. 
Semiretisporis Reinhardt 1962

57. Semiretisporis gothae Rheinhardt 1962

\& 58. Semiretisporis maljawkinae E. Schulz 1967

Pl. 4 fig. 12. Tables I/82, III/84, IV/45.

Heliosporites E. Schulz 1962

59. Heliosporites altmarkensis E. Schulz 1962

Pl. 5 fig. 4. Tables I/43 \& III/113.

H. altmarkensis is identical with "Kraeuselisporites reissingeri (Harris 1957) Morbey 1975', The latter is considered to be a nomen nudum since the "holotype"' was not preserved after being photographed (Harris 1957 p. 305, Reissinger 1949 p. 101).

Heliosporites altmarkensis differs from the Carnian Kraeuselisporites species described by Leschik 1955 (see also Scheuring 1975) by a more spongious exine structure without a massive "tectum".

\section{Perotriletes}

60. Perotriletes globosus Leschik 1955, species n. comb.

Pl. 5 fig. 5. Tables I/78 \& III/101.

1955 Apiculatisporites globosus Leschik 1955 p. 18, pl. 2 fig. 11*.

1967 Densoisporites spongiosus E. Schulz p. 581, pl. 12 figs. 1-3.

P. globosus is distinguished from other species of Perotriletes by its closely fitting "perine". It cannot be assigned to Densoisporites (Weyland \& Krieger 1953) Dettmann 1963 due to absence of apical papillae and presence of the mentioned "perine".

Perinosporites E. Schulz 1962

61. Perinosporites thuringiacus E. Schulz 1962

PI. 5 fig. 6. Tables I/72 \& III/93.

Lycopodiacidites Couper 1953

62. Lycopodiacidites rugulatus (Couper 1958) E. Schulz 1967

P1. 5 fig. 8. Tables I/79, III/88 \& IV/55.

63. Lycopodiacidites rhaeticus E. Schulz 1967

Pl. 5 fig. 9. Tables III/86 \& IV/50.

Camarozonosporites Pant 1954 ex Potonie 1956

C. should probably be united with Lycopodiacidites Couper 1953. C. is used here to avoid more new combinations. 
64. Camarozonosporites rudis (Leschik 1955) Klaus 1960

Pl. 5 fig. 7 Tables III/87 \& IV/35.

65. Camarozonosporites laevigatus E. Schulz 1967

Pl. 5 fig. 10. Tables I/87 \& III/92.

Zebrasporites (Klaus 1960) E. Schulz 1967.

66. Zebrasporites interscriptus (Thiergart 1949) Klaus 1960

Pl. 5 fig. 11. Tables I/90, III/45 \& IV/51.

This species, known form the Carnian as Z. corneolus (Leschik 1955) Klaus 1960 , is also present in the Munkerup Clay and ranges at least from Carnian to Lias alfa 3.

67. Zebrasporites laevigatus (E. Schulz 1962) E. Schulz 1967

Pl. 5 fig. 12. Tables $\mathrm{I} / 88$ \& $\mathrm{III} / 85$.

Tigrisporites Klaus 1960

68. Tigrisporites microrugulatus E. Schulz 1967

Pl. 5 fig. 13. Tables I/73, II/55, III/81.

Tripartitites (Schemel 1950) Potonie \& Kremp 1954

$T$. is a characteristic Carbonifereous type not known from European Permian and pre-Rhaetic Triassic deposits. Balme (1970 pl. 3 fig. 6-8) found this group in the Upper Permian of Pakistan. It may suggest that this Carboniferous genus survived outside Europa in the Permian and Triassic and reimmigrated in Europe in the Rhaetic Liassic.

69. Tripartites mesozoicus Rogalska 1962

Pl. 5, fig. 14. Table III/94.

Triancoraesporites E. Schulz 1962

70. Triancoraesporites reticulatus E. Schulz 1962

Pl. 5 fig. 15. Table III/96.

71. Triancoraesporites ancorae (Reinhardt 1962) E. Schulz 1967

Pl. 5 fig. 16. Tables I/91 \& III/80.

Cornutisporites E. Schulz 1962

72. Cornutisporites seebergensis E. Schulz 1962

Pl. 5 fig. 17. Tables I/93 \& III/95. 


\subsubsection{Monolete microspores}

Some microspores with a mixed trilete-monolete aperture were treated in passage 17.2.3. (see 29. Apiculatisporites parvispinosus (Leschik) E. Schulz, 35. Polypodiisporites polymicroforatus (Orl.-Zwol.) n. comb. and 36. P. ipsviensis (de Jersey) Playford \& Dettmann).

Laevigatosporites (Ibrahim 1933) Potonie \& Kremp 1956

73. Laevigatosporites mesozoicus E. Schulz 1967

Pl. 6 fig. 1. Table III/79.

Marattisporites Couper 1958

74. Marattisporites scabratus Couper 1958

Pl. 6 fig. 2. Table I/94, III/64 \& IV/12.

Aratrisporites (Leschik 1955) Playford \& Dettmann 1965

75. Aratrisporites fimbriatus (Klaus 1960) Mädler 1964

Pl. 6 fig. 3. Tables $\mathrm{I} / 83$ \& III/10.

A. fribriatus differs from the smaller 76. A. minimus also be the presence of scattered spines about 3 microns high.

Aratrisporites palettae (Klaus 1960) Playford \& Dettmann 1965 is a junior synonym of $A$. fimbriatus as noted by Morebey (1975).

76. Aratrisporites minimus Schulz 1967

Pl. 6 fig. $4 \& 5$. Table III/112.

On basis of the morphology E. Schulz (1967) considered A. minimus to be dispers microspores of Lycostrobus possibly of L. scotti. In Rødby No. 1 (Table III) A. minimus occurs together with Nathorstisporites hopliticus which represents dispers megaspores of $L$. scotti. (For data on megaspores see Bertelsen \& Michelsen 1970). Hence A. minimus probably represents dispers microspores of Lycostrobus scotti at least in Rødby 1.

According to E. Schulz (1967) A. minimus do not occur above Lias alfa 2. However, M. Rogalska has also found this species in the Lias alfa 3 of Poland (personal communication).

\subsection{Pollen}

17.3.1. Monocolpate pollen

Chasmatosporites Nilsson 1958 
Chasmatosporites is a characteristic and common element in Liassic floras of northern Europe, but ranges from the Rhaetic to at least the Middle Jurassic (E. Schulz 1967 Tralau 1968 etc.).

Due to presence of a infrareticulate wallstructure and a typical sulcus with infolded thin exine Chasmatosporites is now generally recognized to be a monosulcate pollen and not a monolete spore as claimed by Nilsson (Nilsson 1958, Playford \& Dettmann 1965, Schulz 1967 etc.).

The three species of Chasmatosporites found here do all have a distinct tectum, the thickness of which constitutes at least a quarter of the total wall thickness.

77. Chasmatosporites hians Nilsson 1958

Pl. 6 fig. 6. Tables I/20, II/37, III/31 \& IV/19.

This species is characterized by the irregular nearly vermiculate infrareticulum and fairly big size (length about 50 microns).

78. Chasmatosporites elegans Nilsson 1958

Pl. 6 fig. $7 \& 8$, pl. 12 fig. $10^{*}$. Tables I/48, III/65 \& IV/46.

Distinguished from $C$. hians by a regular microinfrareticulum.

This species should possibly be considered to be a junior synonym of "Monosulcites" subgranulosus Couper 1958.

79. Chasmatosporites apertus (Rogalska 1954) Nilsson 1958

Pl. 6 fig. 9. Tables I/21, III/66 \& IV/66.

Characteristic of $C$. apertus is a semicircular to oval amb and an oval to rectangular sulcus. The microinfrareticulum can be nearly indisernible, obscured by a thick tectum with a exterior "negative reticulum".

\section{Monosulcites Cookson 1947 ex Couper 1953}

To avoid more new combinations Monosulcites Cookson ex Couper is used here although this genus seems to be a junior synonym of Cycadopites Woodehouse ex Wilson \& Webster 1946.

80. Monosulcites minimus Couper 1958

Pl. 6 fig. 10. Tables I/42, II/33, III/29 \& IV/13.

81. Monosulcites punctatus Orlowska-Zwolinska 1966

Pl. 6 fig. 11. Tables I/9, II/4 \& III/14. 
Similar to Chasmatosporites elegans but slender and with a much thinner tectum (semitectate?).

82. Monosulcites cf. punctatus Orlowska-Zwol. 1966

Pl. 6 fig. 12. Tables I/8 \& III/30.

As $M$. punctatus but interior with several layers of thin exine (folded sulcus bottom and/or loosened endexine?).

83. Monosulcites perforatus Mädler 1964b

Table I/1.

Echinitosporites Schulz \& Krutzsch 1961

84. Echinitosporites iliacoides E. Schulz et Krutzsch 1961

Pl. 7 fig. 16. Table III/2.

Presence of a single possible redeposited specimen of $E$. iliacoides in Rødby 1 , is the youngest known European occurrence of this species which are often common in the Lower Keuper of Europe.

85. Gen. et sp. indet

Pl. 7 fig. 17. Tables II/1 \& III/3.

Clavatipollenites Couper 1958

86. Clavatipollenites hughesi Couper 1958

Pl. 6 fig. 14. Tables I/101, III/118 \& IV/67.

This species ranges from the Lower Jurassic to the Lower Cretaceous and is, when present, highly useful to distinguish the Liassic from the Rhaetic. According to E. Schulz (1967) it appears at the Triassic/Jurassic boundary and ranges into the Lower Cretaceous. In the present material it does not occur below the Lias alfa 2 (Upper Hettangian).

Ricciisporites Lundblad 1954

87. Ricciisporites tuberculatus Lundblad 1954

Pl. 6 fig. 13. Tables I/32, II/18, III/17 \& IV/14.

$R$. tuberculatus differs mainly from 44 . tetrads of Uvaesporites sp. by presence of a typical gymnospermeous sulcus (distal, elongate, thinwalled area, infolded with broad ends and a "narrow" middle part) at each of the "4 grains" in the tetrad.

$R$. tuberculatus ranges the Lower Rhaetic to Lias alfa. It reaches its acme in the Middle to Upper Rhaetic and is rare in the Lias alfa (see also passage 5 ect.). 


\subsubsection{Pseudo-tricolpate pollen}

Eucommiidites (Erdtmann) Couper

88. Eucommiidites troedsoni Erdtmann 1948

Pl. 6 fig. 15. Tables I/70, III/67 \& IV/40.

It is noteworthy that this characteristic species, which is known from many Jurassic and Lower Cretaceous microfloras appears already in the Middle Rhaetic.

89. Eucommiidites major E. Schulz 1967

Pl. 6 fig. 16. Tables I/4, II/5 \& III/5.

E. major differs from $E$. troedsoni (length ca. 30 microns) by its bigger size with a length of about 70 microns. Some specimens resemble Ovalipollis ovalis but lack the distinct microreticulate exine structure of the latter species.

E. major is a good indicator of Lower Rhaetic strata in the investigated area.

\subsubsection{Ephedroid pollen}

Ephedripites Bolch. 1953 ex Potonie 1958

90. Ephedripites torosus Mädler 1964a

Pl. 7 fig. 1. Tables I/80, III/117 \& IV/29.

\subsubsection{Porate pollen}

Corollina (Maljavkina 1949) Cornet \& Traverse 1975

In the literature this type of pollen is often found under the name Classopollis Pflug 1953. Cornet \& Traverse (1975) showed in a thorough and convincing discussion that Classopollis is best regarded as a junior synonym of Corollina. Presence of circumequatorial striations is not a diagnostic character of Corollina/Classopollis although this has been claimed in the literature (i.e. Pocock \& Jansonius 1961, Morbey 1975). The neotype of Corollina (new photo in Cornet \& Traverse 1975, pl. 5 fig. 10), which I have personally seen in Vienna, possesses no circumequatorial striations and the short equatorial intrarugulae - made up of confluent granulae - show no uniform orientation. At the genotype of Classopollis such striations are also absent as noted by Mädler (1968 p. 360).

91. Corollina torosus (Reissinger 1950) Klaus 1960

P1. 7 fig. 2, 3 \& 4. Tables I/22, II/19, III/16 \& IV/20. 
Equatorial pseudostriations made up of aligned flat intrabaculae can be present (i.e. pl. 7, fig. 3) or not (i.e. pl. 7, fig. 4). No specimens with unbroken circumequatorial striations were found in the present material. Probably such forms (“Classopollis” striatus Mädler 1968) do not appear until the Upper Liassic.

Corollina torosus s.1. equals about Classopollis classoides Pflug 1953, Classopollis chateaunovi Reyre 1970, ? Classopollis kieseri Reyre 1970 and Corollina murphy Cornet \& Traverse 1975.

92. Corollina zwolinskai n. sp.

Pl. 7 fig. 5. Tables I/10, II/20, III/39 \& IV/43.

Holotype: Specimen shown on pl. 7 fig. 5. Single grain slide R 1930 SG 20.

Holotype locality and stratum: Rødby No. 1 Well at 1930 feet below Kelly Bushing. Middle Rhaetic.

Diagnosis: A species of Corollina with 2 subsequatorial ring furrows (rimulae) one distal and one proximal from the equator.

Description: Subspherical to oblate single pollen, equatorial diameter (20 specimens): 22-30 microns (median xx microns). Distal pore and proximal trilete mark indistinct. With two subequatorial ring furrows, one distal and one proximal of equator. Exine ca. 1 micron thick, smooth, tegillate, intrastructure hardly perceptible (intra microreticulate?), no equatorial striations.

Remarks: A few doubtful specimens with a divided spiral "ring" furrow are included in $C$. zwolinskai on the stratigraphic tables. In the sample with the holotype ( $\mathrm{R} 1930$ feet) the $10.1 \%$ C. zwolinskai noted represent $8.9 \%$ typical and $1.2 \%$ doubtful specimens. C. zwolinskai differs from most Corollina species by its nearly structureless exine. C. meyeriana (Klaus) Venkatachala \& Goćzán is also nearly structureless, but has only one ring furrow.

C. zwolinskai is placed in Corollina and not in a new genus characterized by two ring furrows. Such a new genus would probably show up to be a junior synonym of Corollina, the holotype which possibly also has two ringfurrows one distal and one nearly at the equator (acc. to personal reinvestigation of neotype).

In the investigated material $C$. zwolinskai occurs in the Lower and Middle Rhaetic. It was reported from the Lower Rhaetic of Poland associated with Enzonalasporites and Corollina torosus (acc. Grodzicka-Szymanko \& Orlowska-Zwolinska 1972, pl. 3, fig. 28) and British (?) Midle Rhaetic associated with Rhaetipollis germanicus and Limbosporites lundbladi (acc. Morbey 1975 pl. 12 fig. 10). 
Granuloperculatipollis Ventakatachala \& Goczan 1964

93. Granuloperculatipollis rudis Venkatachala \& Goczan 1964

Pl. 7 fig. 6. Tables I/3, II/6 \& III/20.

$G$. rudis pocesses a semidistal ringfurrow, a faintly developed intrabaculate structure and occurs both as single grains and in tetrads. Hence it is probably closely related to 91 . Corollina (torosus). G. rudis is distinguished by a sculpture of about 1 micron big gemmulae.

At tables I-III some doubtful specimens with microgranulate to microbaculate sculpture have been included in $G$. rudis. They are marked with a questionmark.

Classopollis quezeli Medus 1970 known from the post Carnian Triassic of Sahara is probably identical with G. rudis. Morbey (1975) considered the Carnian species Spiritisporites spirabilis Scheuring 1970 to be a junior synonym of $G$. rudis. As Scheuring did not mention presence of a semidistal ringfurrow and of intrabaculae, and because these features are definitely absent at the holotype of $S$. spirabilis, which I have reinvestigated, I tentatively consider this species to be separate from $G$. rudis.

In Northern Europe G. rudis is regular to common in the Lower Rhaetic and rare in the Middle Rhaetic. In the Alpine area it is also common in possible Middle Rhaetic with rare Limbosporites lundbladi Nilsson (acc. to Morbey 1975).

94. Granuloperculatispollis $\mathrm{sp} .1$

Pl. 7 fig. 7. Tables I/2, II/7 \& III/19.

Rhaetispollis E. Schulz 1967

95. Rhaetispollis germanicus E. Schulz 1967

P1. 7 fig. 8. Tables I/28, II/21, III/41 \& IV/36.

$R$. germanicus is a distinctive and stratigraphically very important Rhaetic species that appears in the "Lower Rhaetic postera-Schichten". It occurs probably in the Middle Rhaetic and only sporadically (? redeposited) in the Upper Rhaetic of the investigated area.

96. Cf. Rhaetipollis sp.

Pl. 7 fig. 9. Tables III/99.

Only one subequatorial ringfurrow is present.

Perinopollenites Couper 1958

97. Perinopollenites elatoides Couper 1958

Pl. 7 fig. 10. Tables I/18, III/33 \& IV/6. 
No pore was observed by this species, which is identical with Ballosporites hians Mädler 1964. The pore claimed to be present by Couper is not convincing in his figures (Couper 1958, pl. 27, fig. 9-11).

98. Perinopollenites cf. elatoides Couper 1958

Pl. 7 fig. 11. Tables I/31, II/22, III/68 \& IV/26.

The specimens determined as $P$. cf. elatoides differs from $P$. elatoides specimens by having a more thickened inner body and tiny folds at the outer body. A pore is often present. Briche et al. (1963) used $P$. cf. elatoides in a similar sence.

Araucariacites Cookson 1947

99. Araucariacites australis Cookson 1947

Pl. 7 fig. 12. Tables I/55, II/48, III/12 \& IV/23.

Specimens referred to $A$. australis have a fairly thick exine (ca. $1 \frac{112-21 / 2}{2}$ microns), and occur in the present material only regularly in the Middle (to Upper) Rhaetic.

100. Araucariacites cf. australis Cookson 1947

Pl. 7 fig. 13. Tables I/23, II/47, III/32 \& IV/21.

A. cf. australis covers thinwalled specimens (exine ca. 1/2-1 micron thick) and is not stratigraphically useful.

Cerebropollenites Nilsson 1958

101. Cerebropollenites macroverrucosus (Thiergart 1949) E. Schulz 1967

Pl. 7 fig. 14. Tables I/102, III/122 \& IV/69.

The incoming of $C$. macroverrucosus ( $=C$. mesozoicus (Couper) Nilsson) in the late Lias alfa 2 and early Lias alfa 3 (see passage 6.7.) is an important marker horizon and reflects the final establishment of the typical Liassic/Jurassic microfloras.

102. Cerebropollenites thiergarti E. Schulz 1967

Pl. 7 fig. 15. Tables I/99, II/56, III/89 \& IV/59.

C. thiergarti is distinguished from C. macroverrucosus by having a distinct even endexine and more or less massive sculptural elements. It differs from "Chasmatosporites (apertus)" specimens with a uneven tectum mainly by the higher sculpture, but this distinction is not sharp in the Middle Rhaetic. 
103. Enzonalasporites spp. (Leschik 1955) E. Schulz 1967

Pl. 7 fig. 18. Tables I/6, II/8 \& III/6.

Enzonalasporites differs from Cerebropollenites mainly by smaller size (ca. 35 microns and ca. 50 microns respectively) and a much more finely convoluted surface.

Enzonalasporites has its acme in the Middle Keuper and is only regularly present in the Lower Rhaetic of the investigated material. In younger deposits only rare, badly preserved, possibly redeposited specimens were found.

\subsubsection{Saccate pollen}

Ovalipollis Krutzsch 1955

Ovapollis has its acme in the Middle Keuper. Next to Corollina/Granuloperculatipollis it is the most common species in the "Lower Rhaetic" of the investigated material.

$O$. notabilis occurs regularly only in the Lower Rhaetic and is unknown in the Jurassic. $O$. ovalis and $O$. breviformis are still regular to common in the Middle Rhaetic and are rare in the Upper Rhaetic and in the Lias alfa.

104. Ovalipollis ovalis Krutzsch 1955

Pl. 8 fig. 1. Tables I/24, II/23, III/15 \& IV/68.

105. Ovalipollis breviformis Krutzsch 1955

Pl. 8 fig. 2. Tables I/24, II/24 \& III/8.

106. Ovalipollis notabilis Scheuring 1970

Pl. 8 fig. 3. Tables I/13, II/9 \& III/7.

Taeniaesporites Leschik 1955

107. Taeniaesporites rhaeticus E. Schulz 1967

P1. 8 fig. 4. Tables I/30, II/25, III/23 \& IV/2.

\section{Protohaploxipinus Samoilowitz 1953}

Being used widely, although published photographs of the genotype do not exist (Balme 1970, p. 361) Protohaploxipinus has been adapted here. The genus is used according to Balme (1.c.) and is considered to cover Mesostriatites Mädler. Therefore M. hercynicus Mädler is referred to Protohaploxipinus below. 
108. Protohaploxypinus hercynicus Mädler 1964, species n. comb. Pl. 8 fig. 5. Tables II/40 \& III/40.

1964 Mesostriatites hercynicus Mädler 1964b p. 111 pl. 10 fig. 6-7.

This species is also known in the Rhaetic literature as Striatites cf. microcarpus Schaarschmidt (E. Schulz 1967 \& Morbey 1975).

Infernopollenites Scheuring 1970

109. Infernopollenites $\mathrm{sp}$.

Pl. 8 fig. 6. Tables I/46 \& III/90.

Quadraeculina Maljavkina 1949

Pocock (1970) incorporated Quadraeculina in Ovalipollis. Surely two geni have important features in common (one main sulcus/laesure and two smaller sulcoid thinnings at the opposite surface causing some similarity to Eucommiidites). However, the "reduced" sacci are situated at the end of the main sulcus in Ovalipollis and sidewards of the main sulcus in Quadraeculina so that it is possible to keep the two apart. Due to the stratigraphical occurrence (Ovalipollis: mainly Upper Triassic Quadraeculina: mainly Jurassic) I prefer to use these two geni, separately.

110. Quadraeculina anellaeformis Maljavkina 1949

Pl. 8 fig. 7. Tables I/35, II/41, III/69 \& IV/41.

Morbey (1975) gave an exhaustive list of synonyms to which probably only Lobosporites mirus Nilsson 1958 should be added.

Protopinus Bolchovitina 1956

111. Protopinus scanicus Nilsson 1958

Pl. 8 fig. 10. Tables I/54, II/51, III/34 \& IV/48.

This species can be described as a big thinwalled Vesicaspora. Normally the reticulum of the sacs is "one layered" with low straight muri surrounding closed polygonal lumina (muri ca. $1 / 2$ micron broad lumina ca. $2(-4)$ micron in diameter).

Vitreisporites Leschik 1955

Mädler (1964b) considered Vitreisporites and Caytonipollenites - which Couper in 1958 established unaware of Vitreisporites - to be different due to the presence of a trilete mark by the former. I have reinvestigated the type material of Leschik and did not find any trilete mark: at the genotype a faint imprint of a crystal might have lead Leschik to describe a trilete mark. 
112. Vitreisporites pallidus (Reissinger 1950) Nilsson 1958

Pl. 8 fig. 9. Tables I/33, II/26, III/35 \& IV/33.

113. Vitreisporites bjuvensis Nilsson 1958

Pl. 8 fig. 11. Tables I/47, II/27, III/42 \& IV/1.

This species which is restricted to the Lower and Midle Rhaetic is more frequent in the north than in the south of the investigated area, and will probably be of stratigraphical importance in the Rhaetic of the arctic.

\section{Alisporites (Daugherty 1941) Jansonius 1971}

Jansonius (1971) showed that a distal sulcoid structure mainly affecting the endexine is present by the genotype of Alisporites. Falcisporites (Leschik 1956) Klaus 1963 claimed to differ from Alisporites by the presence of a distal sulcus (Klaus 1963) is therefore probably a junior synonym of Alisporites.

114. Alisporites diaphanus Pautsch 1958, species n. comb.

Pl. 8 fig. 12. Tables I/25, II/28, III/11 \& IV/24.

1958 Caytoniales-Pollenites diaphanus Pautsch p. 323, pl. 1 figs. 4 \& 11 .

A. diaphanus differs from the other species of Alisporites found here by smaller size and a tendency to construction of the sacci faintly outside their roots.

M. Pautsch has confirmed the determination of the specimen shown on $\mathrm{pl}$. 8 fig. 12. As Mädler considers the specimen to belong to Scopulisporites minor Mädler 1964b this species is most probably identical with $A$. diaphanus. Both Mädler and Pautsch based their statements (personal communication) on photos of the specimen shown here.

115. Alisporites robustus Nilsson 1958

P1. 9 fig. $1 \& 2$. Tables I/26, II/35, III/70 \& IV/15.

116. Alisporites radialis Leschik 1955, species n. comb.

Pl. 9 fig. 3 \& 4. Tables I/27, II/29, III/71 \& IV/60.

1955 Cunaetisporites radialis Leschik p. 66 pl. 10 fig. $6^{*}$.

A. radialis differs from $A$. robustus mainly by constricted roots of the relatively big bladders, but intermediate specimens occur. A. aequalis, Mädler 1964 b differs from $A$. radialis by having smaller bladders. 
Pinuspollenites (Raatz 1937) Potonie 1958

This genus incorporates grains of Diploxylon-type resembling those found in the recent Pinus silvestris.

117. Pinuspollenites minimus (Couper 1958) Kemp 1970

Pl. 9 fig. $5 \& 6$. Tables I/36, II/30, III/36 \& IV/22.

E. Schulz (1967 p. 596) used Pityosporites (al Taedaepollenites) scarus (Nilsson) E. Schulz for naming pollen of this type. Nilsson intended $P$. scarus to be of Diploxilon type; unfortunately the holotype chosen by him (Nilsson 1958, pl. 7 fig. $16^{*}$ ) is a deformed Haploxilon type.

$P$. minimus is much more common in the Liassic than in the Rhaetic.

118. Pinuspollenites pinoides Nilsson 1958, species n. comb.

Pl. 9 fig. 7. Tables I/75, III/114 \& IV/58.

1958 Sulcatisporites pinoides Nilsson p. 86, pl. 8 fig. $6 \& 7^{\star}$.

This species resembles $P$. minimus but differs by having more than hemispherical bladders nearly the size of spherical central body. The central body has a fairly thick tectum with a sculpture of low closely spaced confluent verrucae.

119. "Pityosporites" neomundanus Leschik 1955

Pl. 9 fig. 8. Tables I/11, II/52, III/4 \& IV/71.

Polonisaccus Mädler 1964b

120. Polonisaccus ferrugineus (Pautsch 1958) Mädler 1964b

Pl. 9 fig. 9. Table III/100.

Chordasporites Klaus 1960

121. Chordasporites platysaccus Mädler 1964b

Pl. 10 fig. 1. Table III/105.

Schismatosporites Nilsson 1958

122. Schismatosporites ovalis Nilsson 1958

Pl. 10 fig. 2. Tables I/34, II/53, III/37 \& IV/47.

Schizosaccus Mädler 1964b

123. Schizosaccus keuperi Mädler 1964b

Pl. 10 fig. 3. Tables I/12 \& III/22. 
S. keuperi differs from 122. Schismatosporites ovalis mainly by bigger bladders and the exine structure of the central body (partly thickened tectum and endexine and a columellae layer only about half as thick as the exine). By $S$. ovalis the exine of the central body is made up almost entirely of the columella-layer, and the tectum and endexine are hardly descernible.

Vesicaspora (Schemel 1951) Wilson \& Venkatachala 1963

124. "Vesicaspora" fuscus (Pautsch 1958) Morbey 1975

Pl. 10 fig. 5. Tables I/29, II/31 \& III/9.

This important Triassic species is also known as Sulcatisporites krauselei Mädler 1964b and Cedripidites microreticulatus Orlowska-Zwolinska 1972.

The generic attribution of this species is doubtful. " $V$." fuscus has a strongly developed equatorial columella-layer between the sacs and is not monosaccate compared to typical species of Vesicaspora. An attribution to Sulcatisporites (Leschik 1955) Mädler 1964 is impossible since the genotype of $S$. (Leschik 1955 pl. 10 fig. $4^{\star}$ ) is a thinwalled lateral-compressed "Pinus Haploxilon'/Alisporites species.

\subsection{Aquatic palynomorphs}

Botryococcus Braun

126. Botryococcus sp.

Pl. 10 fig. 4. Tables I/7, II/13 \& III/123.

In the present material Botryococcus sp. occurs mainly in the Lower Rhaetic of the NW German Basin. This is probably due to the brackish facies developed there (see also p. 11).

Cf. Schizosporis Cookson \& Dettman 1959

127. Cf. Schizosporis sp.

Pl. 10 fig. 6. Tables II/14 \& III/124.

Schizocystia Cookson \& Eisenack 1962

128. Schizocystia cf. rara Playford \& Dettmann 1965

Pl. 10 fig. 7, Pl. 12 fig. 5. Table III/138.

Crassosphaera Cookson \& Manum 1960

129. Crassosphaera sp. 1 (p.)

Pl. 10 fig. 8. Tables I/98, II/2 \& III/142. 
Cymatiosphaera (Wetzel 1933) Deflandre 1954

130. Cymatiosphaera spp.

Pl. 12 fig. 2. Tables I/57, II/54 \& III/128.

Tasmanites Newton 1875

131. Tasmanites sp.

Pl. 12 fig. 1. Tables I/74 \& III/125.

Micrhystridium (Deflandre 1937) Sarjeant 1967

Micrhystridium spp. occurs mainly in marine layers like the Middle Rhaetic and the Liassic in the NW German Basin and the Lias alfa 3 and beta in Scania. In brackish deposits like the Lower Rhaetic in the NW German Basin it is sporadically present and in probable nonmarine deposits like the Upper Rhaetic Triletes Schichten and the Rhaetic and most of Lias alfa 1-2 of Scania it is nearly absent.

By the present investigation a breakdown of $M$. to species level was carried out only on the Rødby samples (see below). In Eitzendorf 8, Maasbüll 1 and in Scania these small palynomorphs were determined only to genus level (Tables I/44, II/32 \& IV/56).

132. Micrhystridium lymensis Wall 1965

Pl. 11 fig. 1. Table III/132.

With a medium number (12-20) of mostly solid spines and a fairly rigid test.

133. Micrhystridium fragile Deflandre 1937

Pl. 11 fig. 2. Table III/133.

Differs from $M$. lymensis mainly by having hollow spines and a more flexible test.

134. Micrhystridium intromittum Wall 1965

Table III/131.

Distinguished by the partly hollow spines (ca. 18) of which a few (?4) are bifurcate at their tips.

135. Micrhystridium ef. karamurzae Sarjeant

Pl. 11 fig. 3. Table III/130.

Distinguished by presence of hollow spines with blunt tips. 
136. Micrhystridium cf. wattonensis Wall 1965

Pl. 11 fig. 4. Table III/134.

Characterized by hollow spines with solid capitate tips. Many of the specimens found have 15-30 spines, and only a few have 50-60 spines as by the typical forms described by Wall (l.c.)).

137. Micrhystridium minutispinosum Wall 1965

Pl. 11 fig. 5 \& 6 . Table III/135.

With many (30-?) hollow short spines.

Leiofusa Eisenack 1938

138. Leiofusa jurassica Cookson \& Eisenack 1958

Pl. 11 fig. 7. Tables I/95, II/3, III/139 \& IV/73.

With two spines only.

Except for a single doubtful specimen in the Lower Rhaetic of Maasbüll 1, this species is restricted to the Liassic in the present material.

Wilsonastrum Jansonius 1962

139. Wilsonastrum colonicum Jansonius 1962

Pl. 11 fig. 8. Tables I/96 \& III/140.

With (3 or) 4 spines.

Domasia Downie 1960

140. Domasia liassica Wall 1965

Pl. 11 fig. 9. Table III/141.

Metaleiofusa Wall 1965

141. Metaleiofusa sp.

Pl. 11 fig. 10. Table III/126.

Veryhachium (Deunff 1954) Downie \& Sarjeant 1963

142. Veryhachium sp. 1

Pl. 11 fig. 11. Table III/127.

With seven spines, six with a bend between the basal part of the spine and the test. At the seventh spine (upper right at illustrated specimen) such a bend is missing.

$V$. sp. 1. is restricted to the Rhaetic in the present material. Similar forms are known from the Permian (Schaarschmidt 1963, pl. 17. fig. 14.: "V. cf. nasicum"). 
143. Veryhachium sp. 2

Table III/136.

About as Veryhachium sp. 1., but with reduced spines.

Dapcodium Evitt 1961

144. Cf. Dapcodium sp.

Pl. 11 fig. 12. Tables I/71 \& III/129.

Gen. indet

145. Gen. et sp. indet

Pl. 11 fig. 13. Table III/137.

\subsection{One probable mosspore from Eitzendorf 8}

Naiaditaspora Orbell 1973

Naiaditaspora harrisi Orbell 1973

Pl. 12 fig. 6. Table I.

Morbey (1975) considered this species to be identical with Porcellispora longdonensis (Clarke) Scheuring. However, these two species seem well differentiated in my material (see also p. 57). Therefore they are tentatively treated as separated species here.

$N$. harrisi probably represents the dispersed microspores of the liverwort Naiadita lanceolata Buckman (see Orbell 1973).

$N$. harrisi was found only in the Lower Rhaetic of Eitzendorf 8. It might be of use for local correlations in the Aller Area.

\section{Appendix I: Depths of samples}

\section{in Grevenhorst 1 and Westerwanna 4}

The investigated four samples originate from the following cores:

Grevenhorst 2:

$2609,0-2615,6 \mathrm{~m} \mathrm{~K}_{2}$

2609,0-2615,6 m K3 Krone

Westerwanna 4:

1392,1-1396,8 m K2

1396,8-1406,8 m K 1 Krone 
Data on the corerecovery were not available. Therefore the precise depths of the samples are not given.

\section{Acknowledgements}

The Geological Survey of Denmark, the Deutsche Texaco AG, the Wintershall AG, the Preussag AG, prof. T. Nilsson, Dr. K. Mädler and Dr. $W$. Zimmerle are thanked for providing samples.

During this study, mainly carried out at the Geological Institute, University of Aarhus, Denmark, many persons have provided valuable help, they are all thanked here, especially Mr. K. Raunsgaard Pedersen, Mrs. B. Larsen and Miss D. Møller. Further Mr. H. Mørck, Mr. W. Schmidt and Dr. $P$. Griggs are thanked for linguistic help, and last but not least $\mathrm{Mr}$. $F$. Bertelsen is thanked for making available the facilities of the Geological Survey of Denmark. 
Table I

Vertical distribution of

Palynomorphs in Eitzendorf 8

(Depth in $\mathrm{m}$ )

1 Monosulcites perforatus (83)

2 Granuloperculatipollis $\mathrm{sp} .1$ (94) ................................ ?

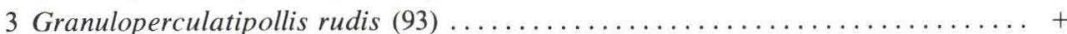

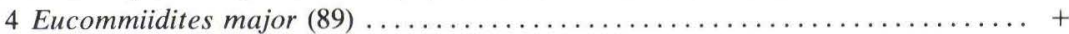

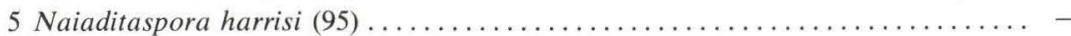

6 Enzonalasporites spp. (103) ................................

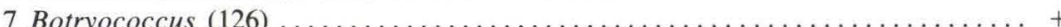

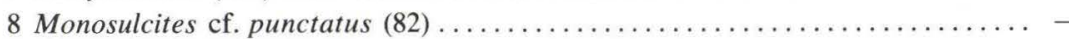

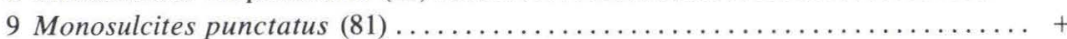

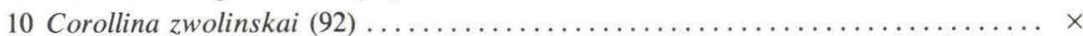

11 "Pityosporites" neomundamus (119) .............................

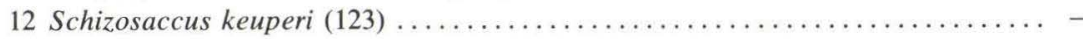

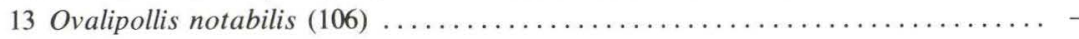

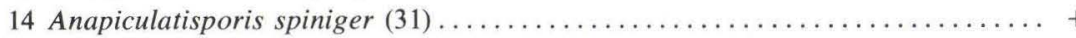

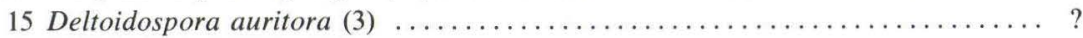

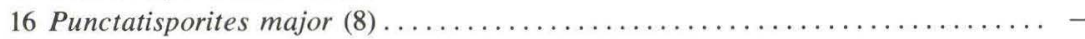

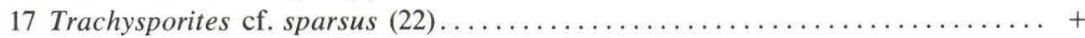

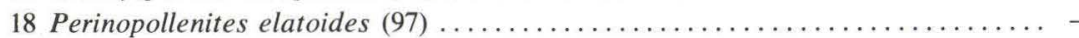

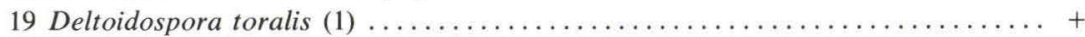

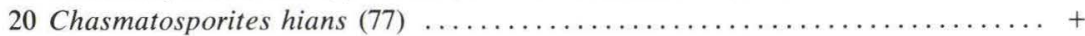

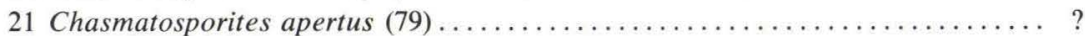

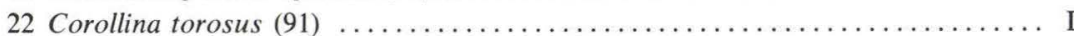

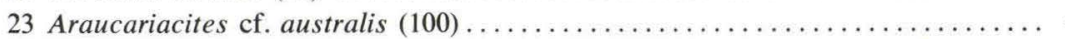

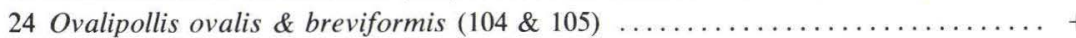

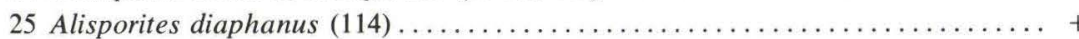

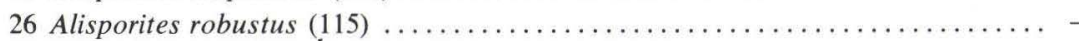

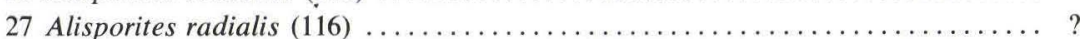

28 Rhaetipollis germanicus (95)

29 "Vesicaspora" fuscus (124)

30 Taeniaesporites rhaeticus (107)

31 Perinopollenites cf. elatoides (98)

32 Ricciisporites tuberculatus (87)

33 Vitreisporites pallidus (112)

34 Schismatosporites ovalis (122)

35 Quadraeculina anellaeformis (110)

36 Pinuspollenites minimus (117)

37 Anapiculatisporis telephorus (32)

38 Contignisporites problematicus (46)

39 Apiculatisporis parvispinosus (29) ...

40 Trachysporites fuscus (20)

41 Trachysporites asper (21)

42 Monosulcites minimus (80)

43 Heliosporites altmarkensis (59)

44 Micrhystridium spp.

45 Apiculatisporis ovalis (28)

46 Infernopollenites sp. (109)

47 Vitreisporites bjuvensis (113)

48 Chasmatosporites elegans (78)

49 Deltoidospora toralis var. media (1 b)

50 Conbaculatisporites mesozoicus (23)

51 Conbaculatisporites spinosus (24)

52 Baculatisporites comaumensis (25)

53 Uvaesporites reissingeri (43) 


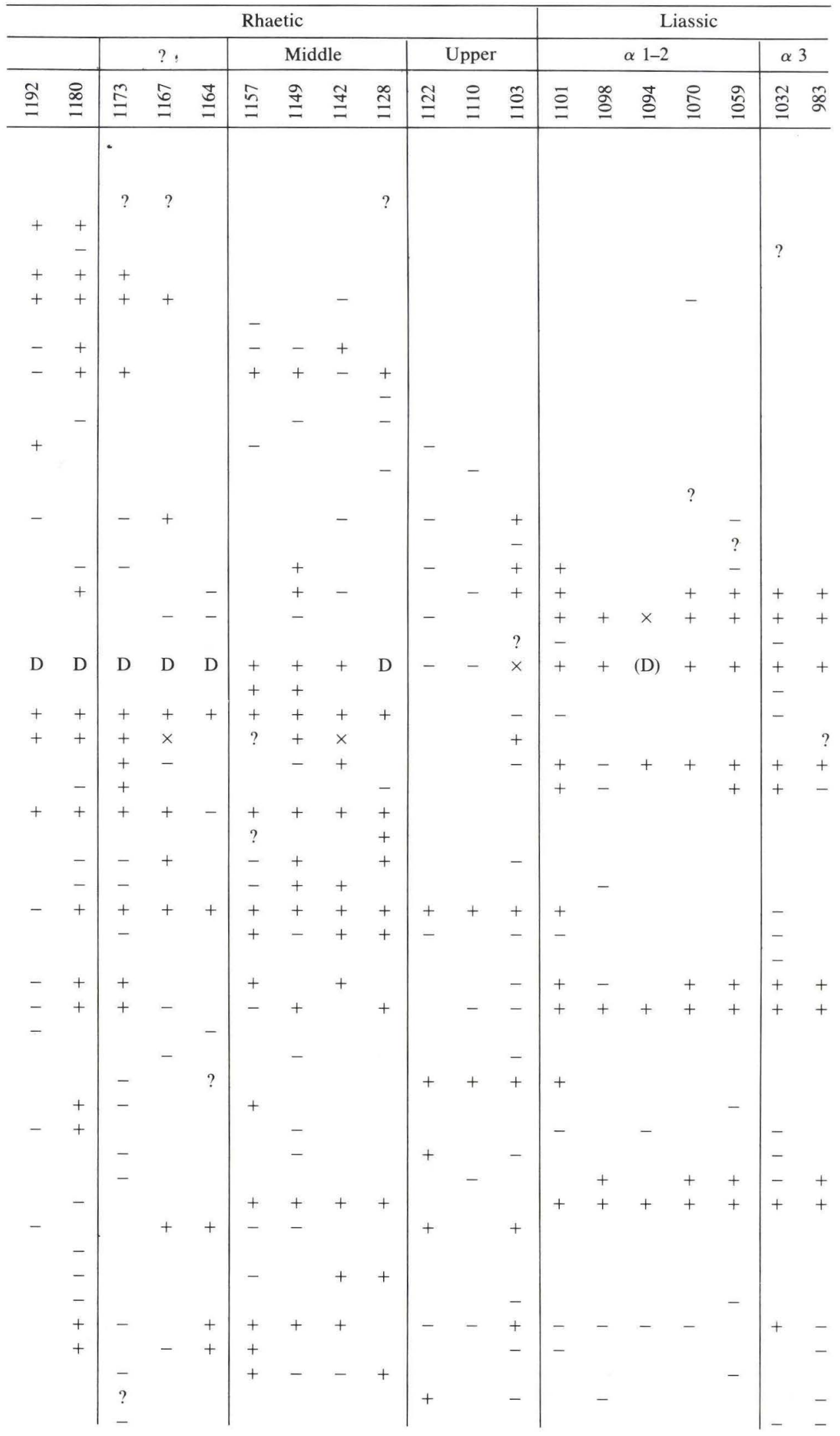


Vertical distribution of

Palynomorphs in Eitzendorf 8

(Depth in $\mathrm{m}$ )

54 Protopinus scanicus (111)

55 Araucariacites australis (99)

56 Uvaesporites of. sanguilentiformis (45)

57 Cymatiosphaera sp. (130)

58 Polypodiisporites ipsviciensis (36)

59 Baculatisporites wellmani (26)

60 Cingulizonates rhaeticus (53)

61 Verrucosisporites sp. (34)

62 Densosporites cf. cerebralis (52)

63 Limbosporites lundbladi (56)

64 Stereisporites cicatricosus (16)

65 Polypodiisporites polymicroforatus (35)

66 Iraquispora speciosa (42)

67 Intrapunctisporis toralis (6)

68 Deltoidospora minor (2)

69 Deltoidospora crassexina (4)

70 Eucommiidites troedsoni (88)

71 Cf. Dapcodium sp. (144)

72 Perinosporites thuringiacus (61)

73 Tigrisporites microgulatus (68)

74 Tasmanites sp. (131)

75 Pinuspollenites pinoides (118)

76 Stereisporites punctus (15)

77 Neochomotriletes triangularis (47)

78 Perotriletes globosus $(60)$

79 Lycopodiacidites rugulatus (62)

80 Ephedripites torosus (90)

81 Densosporites fissus (49)

82 Semiretisporis gothae \& maljawkinae (57/58)

83 Aratrisporites fimbriatus (75)

84 Stereisporites stereoides (13)

85 Stereisporites antiquatisporis (14)

86 Cingulizonates cf. inequalis (55)

87 Camarozonosporites laevigatus (65)

88 Zebrasporites laevigatus (67)

89 Cingulizonates marginatus (54)

90 Zebrasporites interscriptus (66)

91 Triancoraesporites ancorae (71)

92 Calamospora tener (12)

93 Cornutisporites seebergensis (72)

94 Marattisporites scabratus (74)

95 Leiofusa jurassica (138) .

96 Wilsonastrum colonicum (139)

97 Punctatisporites globosus (9)

98 Crassosphaera spp. (129).

99 Cerebropollenites thiergarti (102)

100 Foraminisporis jurassicus (19)

101 Clavatipollenites hughesi (86)

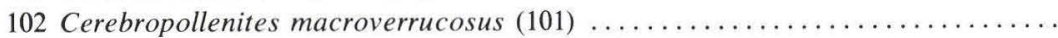

103 Nevesisporites limatulus (18)

104 Lycopodiumsporites austroclavatidites (38)

105 Lycopodiumsporites semimuris (39)

106 Tetrads of Uvaesporites sp. (44) 


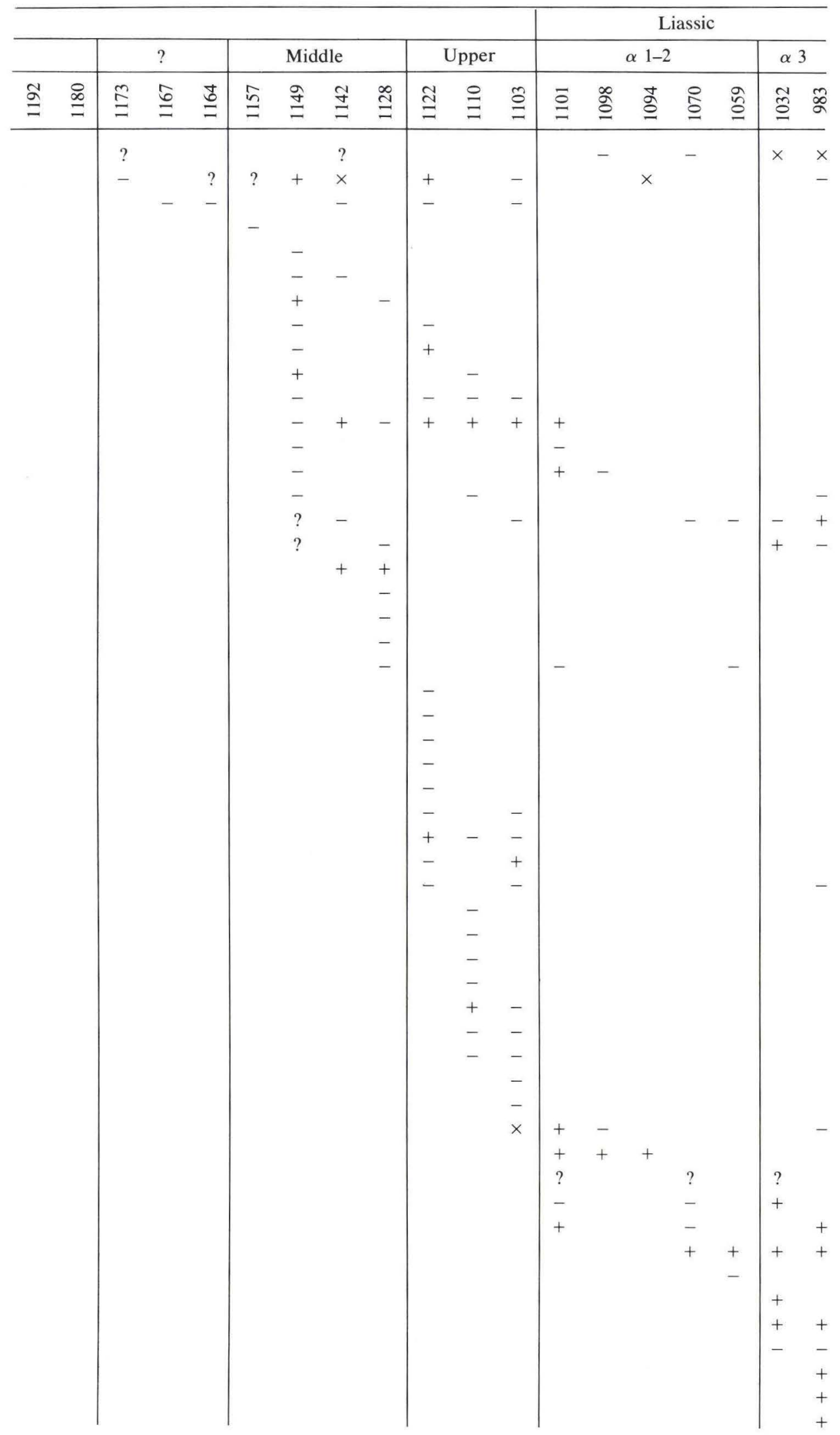


Table II

Vertical distribution of palynomorphs in Maasbüll 1 (Depth in $\mathrm{m}$ )

1 Gen. et sp. indet (85)

2 Crassosphaera sp. (129)

3 Leiofusa jurassica $(138) \ldots \ldots \ldots \ldots \ldots \ldots \ldots \ldots \ldots \ldots \ldots$ ?

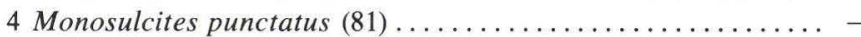

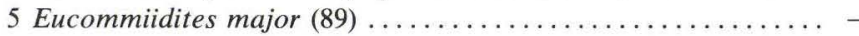

6 Granuloperculatipollis rudis $(93) \ldots \ldots \ldots \ldots \ldots \ldots \ldots \ldots \ldots \ldots$

7 Granuloperculatipollis sp. $1(94) \ldots \ldots \ldots \ldots \ldots \ldots \ldots \ldots \ldots+$

8 Enzonalasporites spp. (103).....................

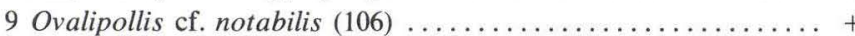

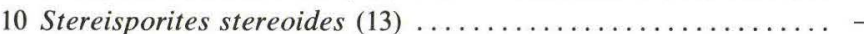

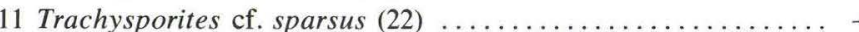

12 Porcellispora longdonensis $(30) \ldots \ldots \ldots \ldots \ldots \ldots \ldots \ldots$ ?

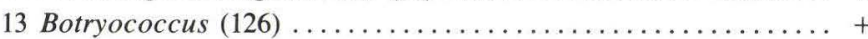

14 Cf. Schizosporis sp. (127) ...................

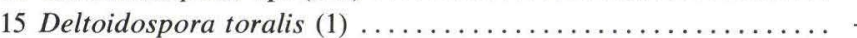

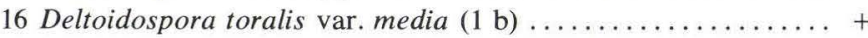

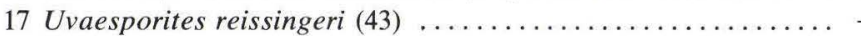

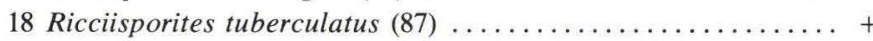

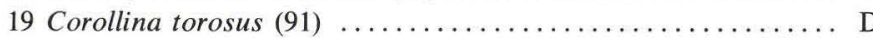

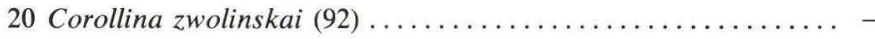

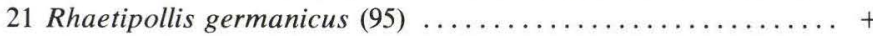

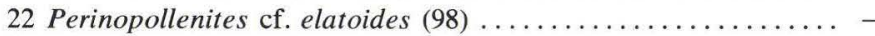

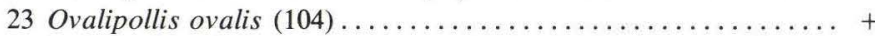

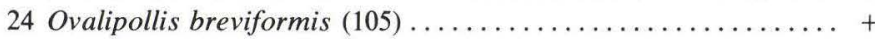

25 Taeniaesporites rhaeticus (107) ................... +

26 Vitreisporites pallidus (112) ...................

27 Vitreisporites bjuvensis (113) ....................

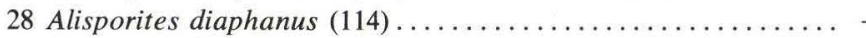

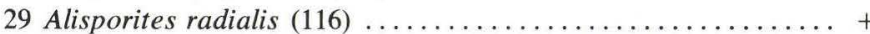

30 Pinuspollenites minimus (117) ................... -

31 "Vesicaspora" fuscus (124) .......................

32 Micrhystridium spp. ....................... +

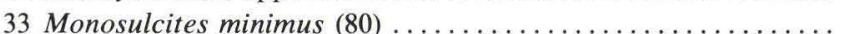

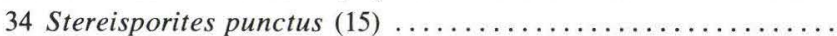

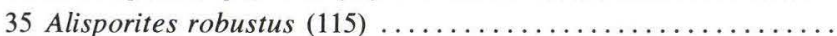

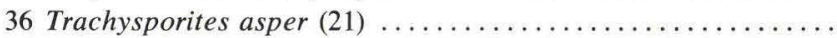

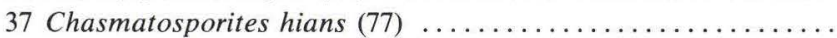

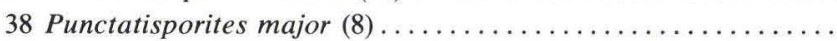

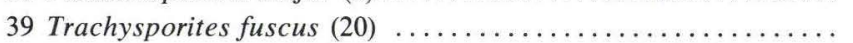

40 Protohapeoxipinus hercynicus $(108) \ldots \ldots \ldots \ldots \ldots \ldots \ldots \ldots$

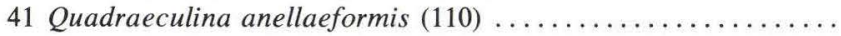

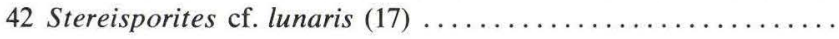

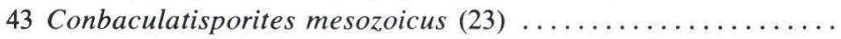


Vertical distribution of Palynomorphs in Maasbüll 1 (Depth in $\mathrm{m}$ )

44 Anapiculatisporites telephorous (32)

45 Lycopodiumsporites austroclavatidites (38)

46 Contignisporites problematicus (46)

47 Araucariacidites cf. australis (100)

48 Araucariacidites australis (99) .

49 Densosporites cf. cerebralis (52)

50 Limbosporites lundbladii (56)

51 Protopinus scanicus (111)

52 "Pityosporites" neomundanus (119)

53 Schismatosporites ovalis (122)

54 Cymatiosphaera sp. (130)

55 Tigrisporites microrugulatus (68)

56 Cerebropollenites thiergartii (102) 


\section{Table III}

Vertical distribution of

Palynomorphs in Rødby 1

(Depth in feet)

1 Porcellispora longdonensis (30)

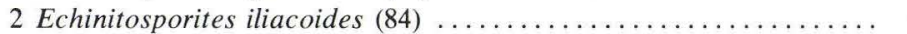

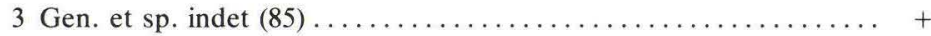

4 "Pityosporites" neomundanus (119) .................... -

5 Eucomiidites major (89) .......................... +

6 Enzonalasporites spp. (103) ....................... +

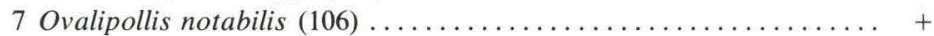

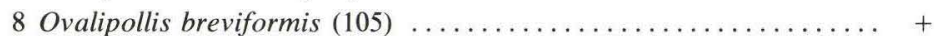

9 "Vesicaspora" fuscus (124) . . . . . . . . . . . . . . . . . . . . . . . -

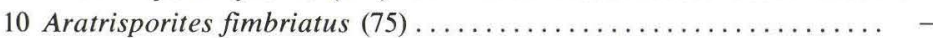

11 Alisporites diaphanus (114) ........................ +

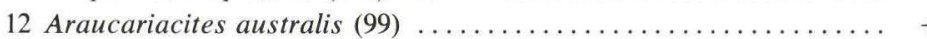

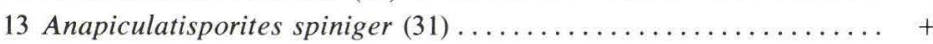

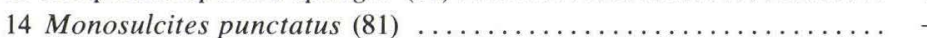

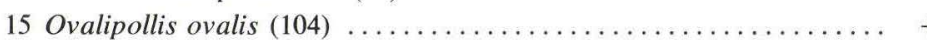

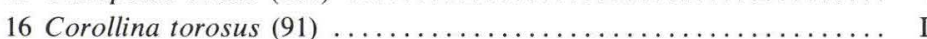

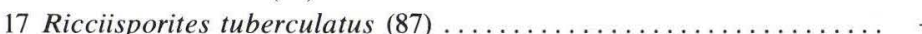

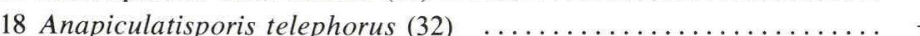

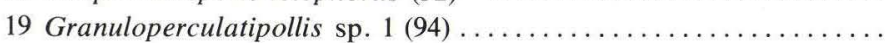

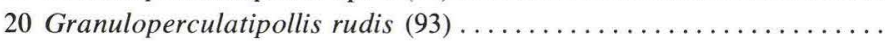

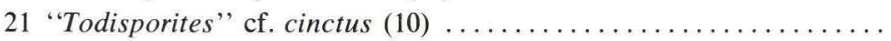

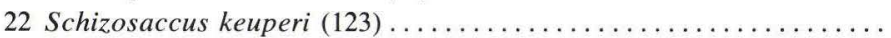

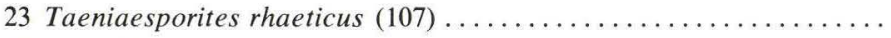

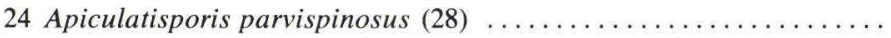

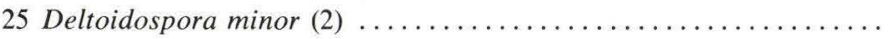

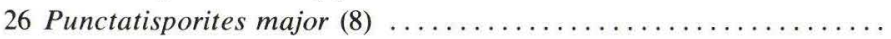

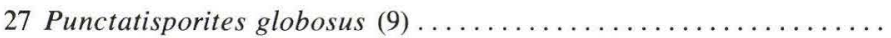

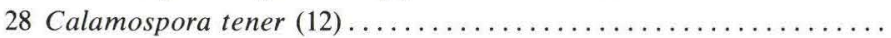

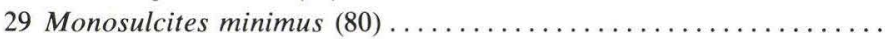

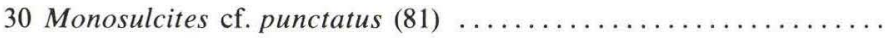

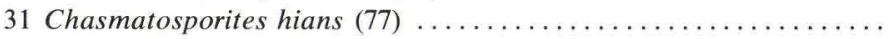

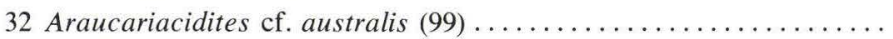

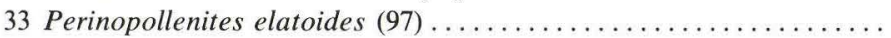

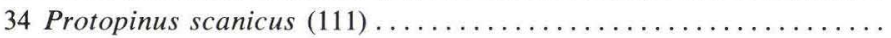

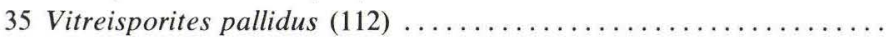

36 Pinuspollenites minimus (117)

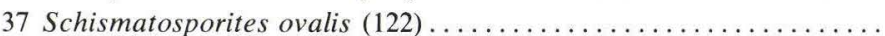

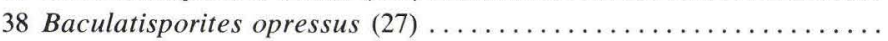

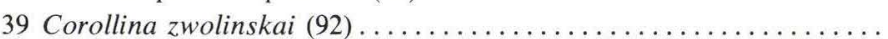

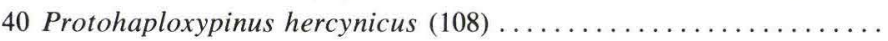

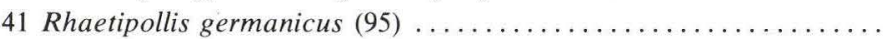

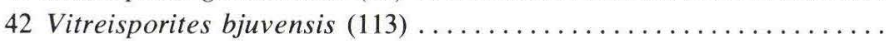

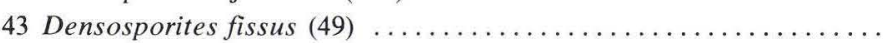

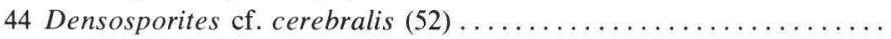

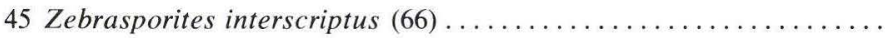

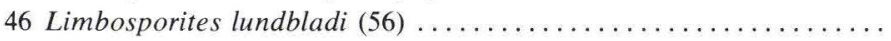

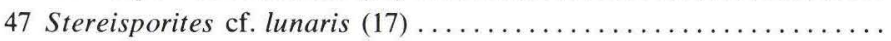

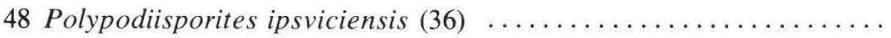

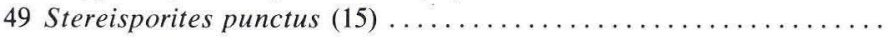

50 Trachysporites ef. sparsus (22)

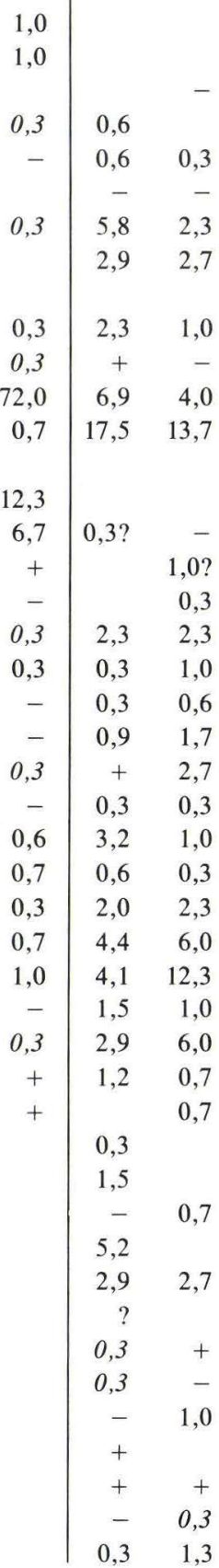




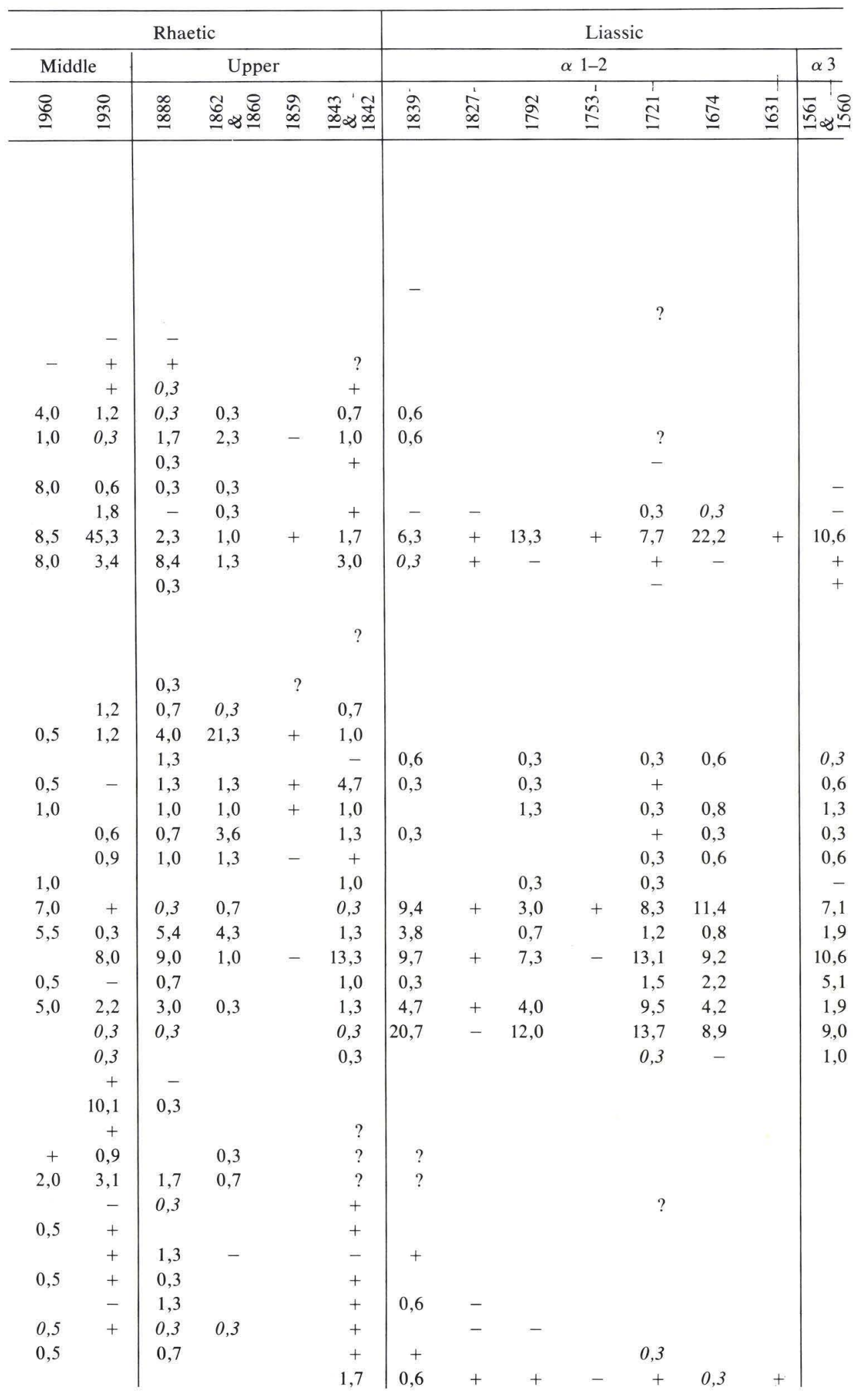


Vertical distribution of

Palynomorphs in Rødby 1

(Depth in feet)

51 Deltoidospora toralis (1)

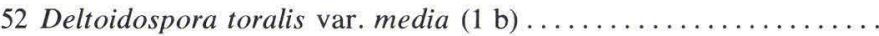

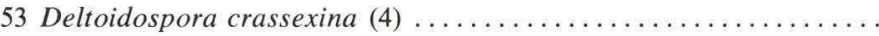

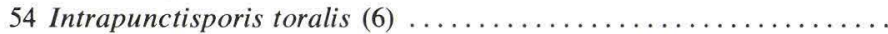

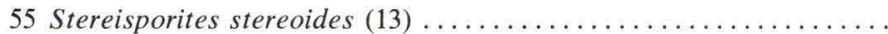

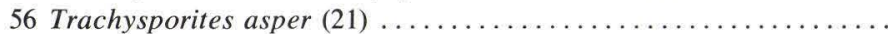

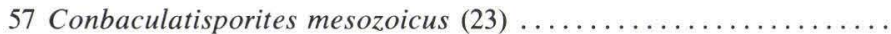

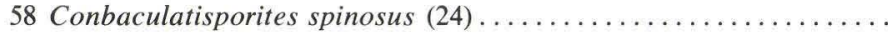

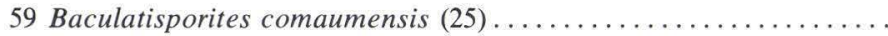

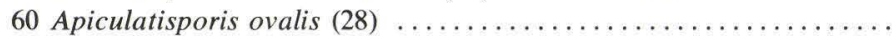

61 Polypodiisporites polymicroforatus (35) $\ldots \ldots \ldots \ldots \ldots \ldots \ldots \ldots$

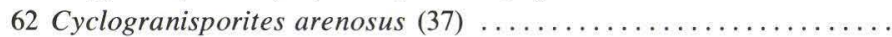

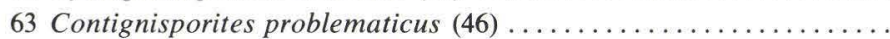

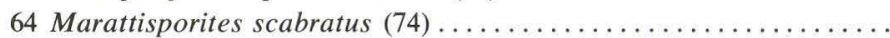

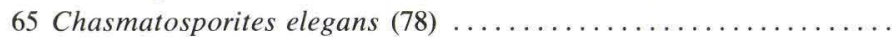

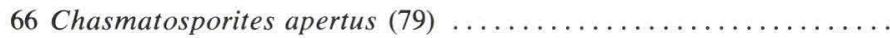

67 Eucommiidites troedsoni (88) . . . . . . . . . . . . . . . . . . .

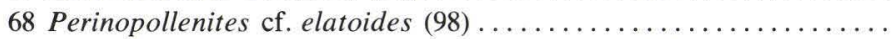

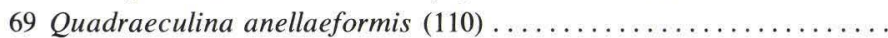

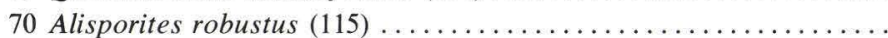

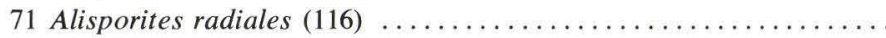

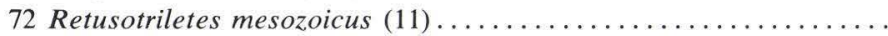

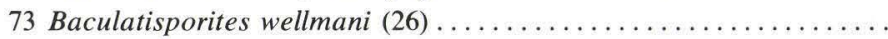

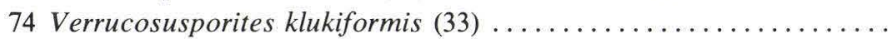

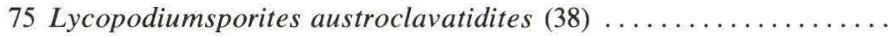

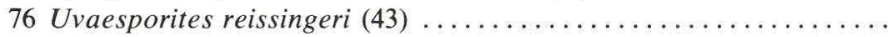

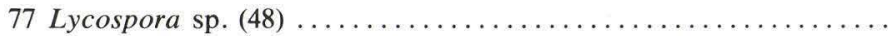

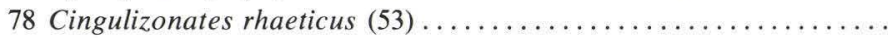

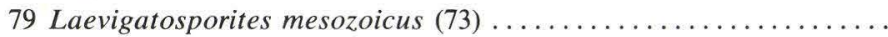

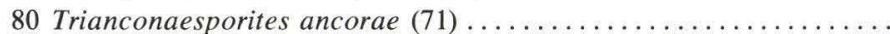

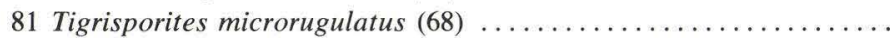

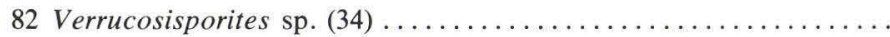

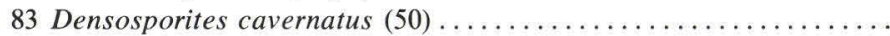

84 Semirerisporis gothae \& maljavkinae $(57 / 58) \ldots \ldots \ldots \ldots \ldots \ldots$

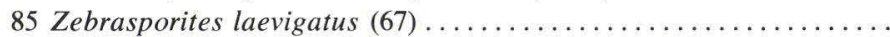

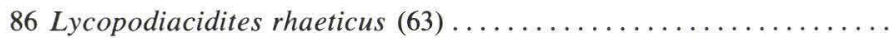

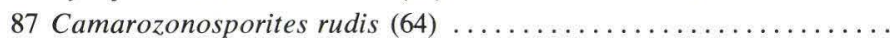

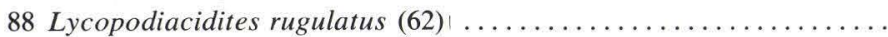

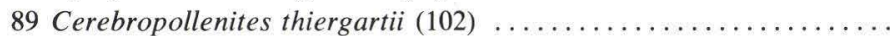

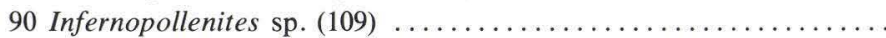

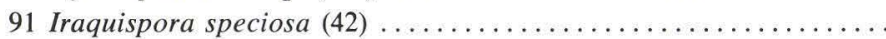

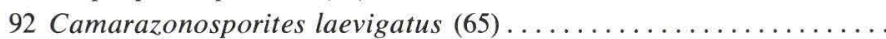

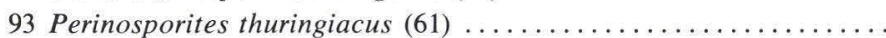

94 Tripartites mesozoicus (69) . . . . . . . . . . . . . . . . . . . . . .

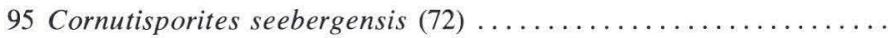

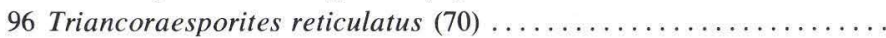

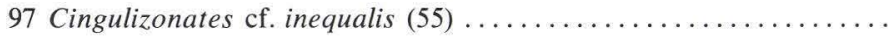

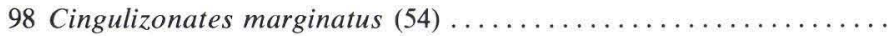

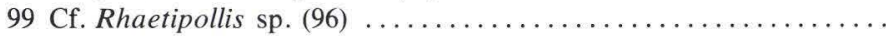

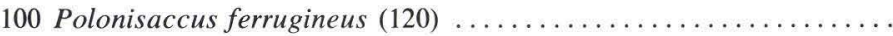

\begin{tabular}{|c|c|c|c|}
\hline \multicolumn{4}{|c|}{ Rhaetic } \\
\hline \multicolumn{2}{|c|}{ Lower } & \multicolumn{2}{|c|}{ Middle } \\
\hline$\stackrel{n}{\approx}$ & సై & $\frac{\tilde{\beta}}{\sim}$ & $\begin{array}{l}\not{D} \\
\stackrel{\sim}{2}\end{array}$ \\
\hline & & 1,8 & 3,0 \\
\hline & & 1,2 & 3,7 \\
\hline & & - & 0,3 \\
\hline & & 0,3 & 0,7 \\
\hline & & - & 1,0 \\
\hline & & 0,3 & 1,0 \\
\hline & & 2,0 & 0,3 \\
\hline & & 0,9 & 1,3 \\
\hline & & 0,6 & 2,0 \\
\hline & & 0,6 & 2,0 \\
\hline & & 1,2 & 2,3 \\
\hline & & 0,3 & \\
\hline & & - & 0,7 \\
\hline & & 1,8 & 3,5 \\
\hline & & 2,9 & 2,7 \\
\hline & & - & 0,3 \\
\hline & & 1,5 & 0,3 \\
\hline & & 2,9 & 2,0 \\
\hline & ? & 0,6 & \\
\hline & ? & + & - \\
\hline & & 5,3 & - \\
\hline & & & 0,7 \\
\hline & & & 0,3 \\
\hline & & & - \\
\hline & & & $\begin{array}{r}0,7 \\
-\end{array}$ \\
\hline & & & 0,3 \\
\hline & & & $\begin{array}{r}+ \\
0,3\end{array}$ \\
\hline
\end{tabular}




\begin{tabular}{|c|c|c|c|c|c|c|c|c|c|c|c|c|c|}
\hline \multicolumn{6}{|c|}{ Rhaetic } & \multicolumn{8}{|c|}{ Liassic } \\
\hline \multicolumn{2}{|c|}{ Middle } & \multicolumn{4}{|c|}{ Upper } & \multicolumn{7}{|c|}{$\alpha 1-2$} & \multirow{2}{*}{$\frac{\alpha 3}{\overline{0}}$} \\
\hline$\stackrel{\circ}{\circ}$ & ळ్ & $\begin{array}{l}\infty \\
\infty \\
\infty\end{array}$ & $\begin{array}{l}\widetilde{D} \\
\infty \\
\infty\end{array}$ & ڤે & $\underset{\infty}{\tilde{\Phi}} \underset{\mathscr{I}}{\mathscr{T}}$ & $\stackrel{\text { ळे }}{\infty}$ & $\begin{array}{l}\dot{1} \\
\stackrel{\infty}{-}\end{array}$ & §ૂ & $\stackrel{1}{\tilde{n}^{1}}$ & $\overline{\mathbb{N}}$ & $\frac{\pi}{6}$ & हु) & \\
\hline 1,5 & 1,5 & 3,7 & 5,3 & + & 17,7 & 9,1 & + & 14,3 & & 13,7 & 8,9 & + & 15,1 \\
\hline 2,0 & 1,2 & 8,0 & 4,6 & + & 13,3 & 11,6 & & 15,7 & & 8,6 & 9,5 & - & 10,6 \\
\hline 1,5 & 0,6 & 1,7 & 0,3 & & 1,7 & 1,6 & & 3,7 & & - & 3,0 & & 4,8 \\
\hline 0,5 & 0,9 & 2,7 & 4,3 & & 1,3 & 1,6 & - & 3,7 & & 1,2 & 0,8 & & 1,9 \\
\hline \multirow[t]{6}{*}{0,5} & 0,6 & 3,0 & 0,3 & & 1,7 & 0,9 & + & 1,7 & & - & 0,3 & & 0,3 \\
\hline & - & & 1,3 & & 0,3 & & & & & & & - & 0,3 \\
\hline & $?$ & & $?$ & & 0,7 & 0,6 & & 0,3 & & 0,9 & 0,8 & & 0,3 \\
\hline & + & & - & & 1,3 & & - & 0,3 & & & 0,8 & & + \\
\hline & 0,3 & 0,3 & 0,3 & & 2,0 & 1,3 & & 0,3 & + & 0,6 & 0,6 & + & 1,9 \\
\hline & 0,3 & - & 1,0 & + & + & - & & - & & 0,3 & 0,6 & & + \\
\hline 2,0 & 0,3 & 8,7 & 16,8 & & 0,7 & 0,3 & & & & + & - & & 0,3 \\
\hline 0,5 & & & & & 0,3 & + & + & & & + & & & 0,6 \\
\hline 2,0 & 0,3 & 6,7 & 14,7 & & 0,7 & 1,9 & - & 7,0 & & 1,5 & 3,2 & & 4,5 \\
\hline 10,5 & 0,3 & 0,7 & 1,0 & & 3,3 & & & & - & 0,3 & - & & 2,3 \\
\hline \multirow[t]{2}{*}{2,0} & 0,3 & & 0,7 & & & 0,3 & + & 1,0 & & 1,2 & 1,9 & & + \\
\hline & & 1,7 & 0,3 & & & & & & & - & - & & - \\
\hline 1,0 & 2,8 & $2 ; 7$ & 3,0 & & 10,6 & 6,3 & & 5,3 & & 8,0 & 1,7 & & 1,9 \\
\hline 0,5 & 0,6 & 0,3 & & & 2,0 & 1,3 & & 0,3 & & 0,6 & + & - & 0,6 \\
\hline \multirow[t]{5}{*}{2,0} & & 0,3 & 0,3 & + & 0,7 & & & - & & 0,9 & & & 1,3 \\
\hline & + & 0,3 & & - & 0,3 & 1,2 & & + & & 0,6 & 0,6 & & - \\
\hline & & & & + & 0,7 & - & & & & - & 0,3 & & \\
\hline & 0,6 & 0,3 & 0,3 & & 0,7 & 0,3 & & - & & + & - & - & + \\
\hline & & & - & - & + & - & & & & - & & & - \\
\hline \multirow[t]{3}{*}{-} & & 0,7 & 0,3 & & 1,3 & - & - & & & & & & 0,6 \\
\hline & 0,3 & & & & - & + & & - & & & - & & 0,3 \\
\hline & 0,6 & - & & & & & & 0,3 & & & & & - \\
\hline \multirow[t]{2}{*}{1,0} & 0,6 & + & & & 0,3 & & & - & & & & & 0,3 \\
\hline & 0,3 & & & & & 0,3 & & & - & + & & & - \\
\hline \multicolumn{14}{|l|}{0,5} \\
\hline- & & 0,3 & & & & & & & & & & & \\
\hline- & & + & + & - & & & & & & & & & \\
\hline- & + & 0,7 & & & - & & & & & & & & \\
\hline 0,5 & - & 2,7 & & & 0,3 & & & & & & & & \\
\hline- & - & 0,7 & & & - & & & & & & & & \\
\hline - & & 0,7 & - & & + & - & & & & & & & \\
\hline 2,0 & - & 0,3 & 0,3 & & 0,3 & & & & & & 0,6 & & \\
\hline- & - & 0,3 & 0,7 & & + & + & & - & & + & + & & + \\
\hline \multirow[t]{12}{*}{0,5} & & 0,3 & 0,3 & & & + & & 0,3 & - & 0,3 & 0,3 & + & + \\
\hline & - & & & & & & & & & & & & \\
\hline & 0,3 & - & & & & & & & & & & & \\
\hline & - & - & & & & & & & & & & & \\
\hline & 0,3 & 0,3 & & & 0,3 & & & & & & & & \\
\hline & - & & & & & & & - & & & & & - \\
\hline & & 0,3 & & & & & & & & & & & \\
\hline & & 0,3 & & & & & & & & & & & \\
\hline & & 0,7 & & & & & & & & & & & \\
\hline & & 0,3 & - & & & & & & & & & & \\
\hline & & 0,3 & & & 1,0 & - & & & & & & & \\
\hline & & 0,3 & & & & 0,3 & & & & & & & \\
\hline
\end{tabular}


Vertical distribution of Palynomorphs in Rødby 1 (Depth in feet)

101 Perotriletes globosus (60)

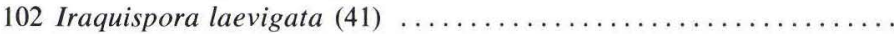

103 Stereisporites cicatricosus (16)

104 Deltoidispora auritora (3)

105 Chordasporites platysaccus (121)

106 Intrapunctisporis hians (6)

107 Stereisporites antiquasporites (14)

108 Ischyosporites $\mathrm{sp}$. cf. I. crateris (40)

109 Deltoidospora sp. (5) ...

110 Neochomotriletes triangularis (47).

111 Trachysporites fuscus (20).

112 Aratrisporites minimus (76)

113 Heliosporites altmarkenois (59) . .

114 Pinuspollenites pinoides (118)

115 Foraminispores jurassicus (19)

116 Densosporites irregularis (51)

117 Ephedripites torosus (90)

118 Clavatipollenites hughesii (86)

119 Lycopodiumsporites semimuris (39)

120 Tetrads of Uvaesporites sp. (44)

121 Uvaesporites cf. sanguilentiformis (45)

122 Cerebropollenites macroverrucosus (101)

Counted number of microspores and pollen grains exclusive of Inaperturates

Inaperturates

(\% of sum of counted microspores and pollen)

Algae (\% of sum of counted microspores and pollen exclusive of Inaperturates):

123 Botryococcus (126).

124 Cf. Schizosporis sp. (127)

125 Tasmanites sp. (p) (131)

126 Metaleiofura sp. (141)

127 Veryhachium sp. 1 (142 a)

128 Cymatiosphaera sp. (130)

129 Cf. Dapcodium (144)

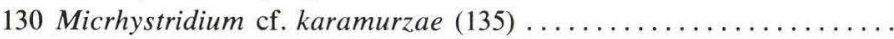

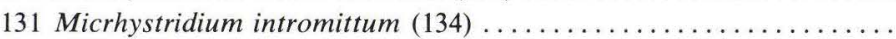

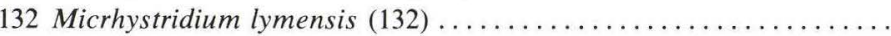

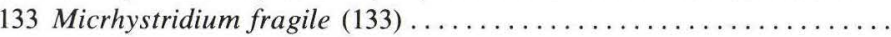

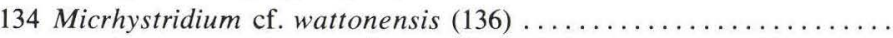

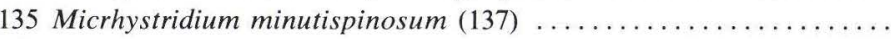

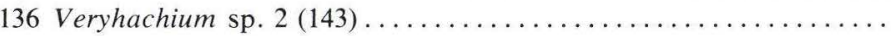

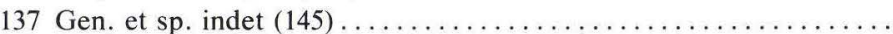

138 Schizocystia cf. rara (128)

139 Leiofusa jurassica (138)

140 Wilsonastrum colonicum (139)

141 Domasia liassica (140)

142 Crassosphaera sp. (129) 


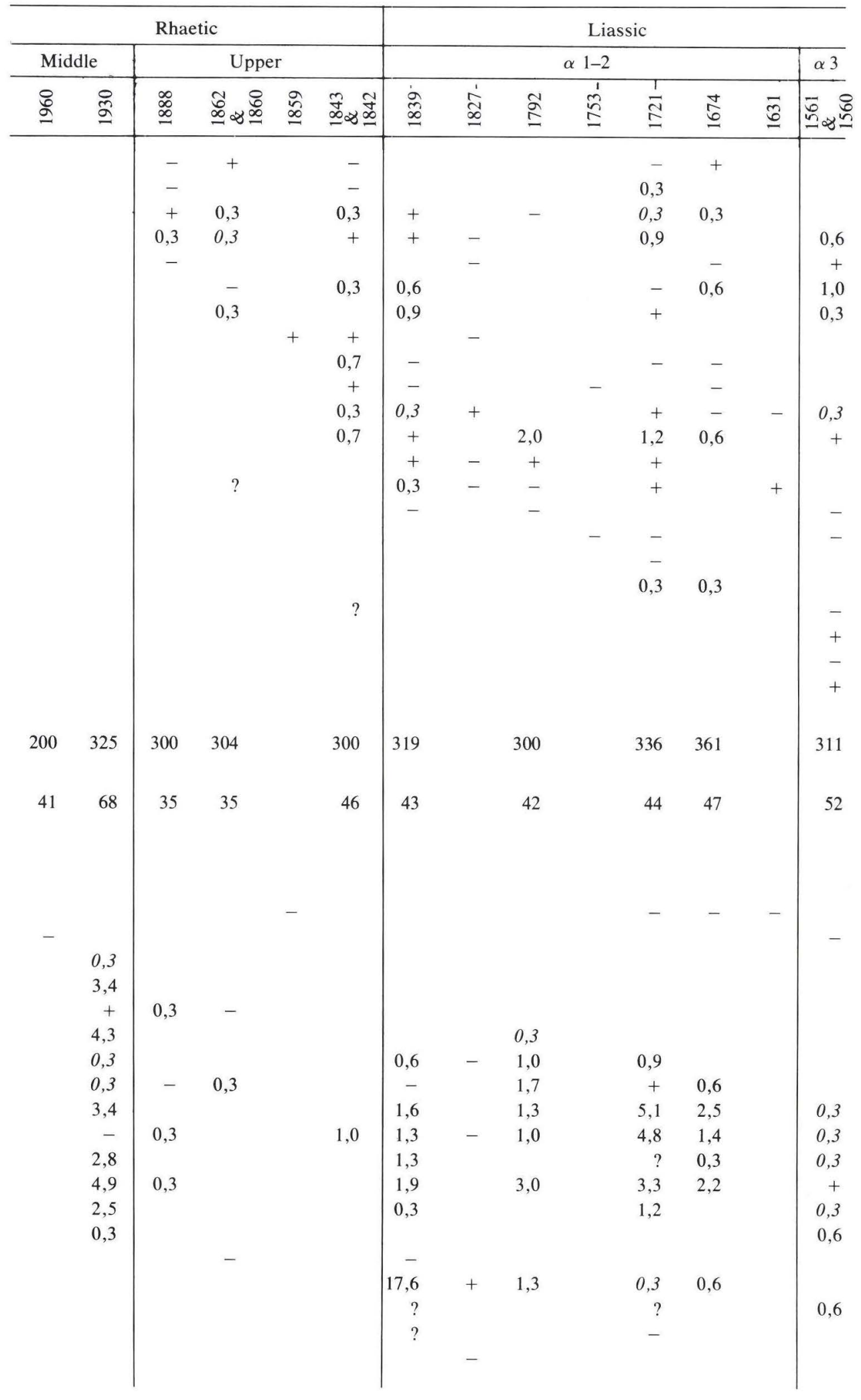


Table IV

Vertical distribution of

palynomorphs in Scania

\begin{tabular}{llllll|lll|ll|ll|l}
\multicolumn{3}{c|}{ Rhaetic } & \multicolumn{7}{c}{ Lias } \\
\hline \multicolumn{3}{c|}{ Middle? } & \multicolumn{2}{c|}{$\alpha$} & 1 & & $\alpha$ & 2 & $\alpha$ & 3 & $\beta$ \\
\hline 1 & 2 & 3 & 4 & 5 & 6 & 7 & 8 & 9 & 10 & 11 & 12 & 13 \\
\hline
\end{tabular}

1 Vitreisporites bjuvensis (113) .......... +

2 Taeniaesporites rhaeticus (107) ........ n

3 Densosporites fissus (49) ............ N

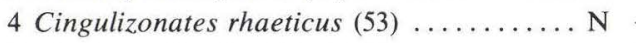

5 Limbosporites lundbladi (56) ........... n -

6 Perinopollenites elatoides $(97) \ldots \ldots \ldots \ldots+$

7 Deltoidospora toralis

var. media $(1 \mathrm{~b}) \ldots \ldots \ldots \ldots \ldots \ldots \ldots \ldots \ldots+$

8 Calamospora tener (12) ............

9 Punctatisporites major (8) ............ -

10 Apiculatisporis ovalis (28) ........... n

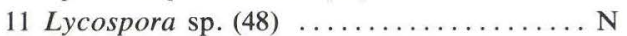

12 Marattisporites scabratus (74) .......... n -

13 Monosulcites minimus (80) ............. -

14 Ricciisporites tuberculatus $(87) \ldots \ldots \ldots \ldots+$

15 Alisporites robustus (115) ...........?

16 Deltoidospora toralis (1) ............ $\mathrm{n}$

17 Deltoidospora crassexinus (4)..........?

18 Lycopodiumsporites austroclavatidites (38)

19 Chasmatosporites hians (77) ..........

20 Corollina torosus (91) ......................

21 Araucariacidites cf. australis 100

22 Pinuspollenites minimus (117)

23 Araucariacidites australis (99) ..........

24 Alisporites diaphanus (114) ............

25 Baculatisporites wellmani (26) ......... +

26 Perinopollenites $\mathrm{cf}$. elatoides (98)

27 Intrapunctisporis toralis (6)

28 Apiculatisporis parvispinosus (29) .......

29 Ephedripites torosus (90) .............

30 Stereisporites stereoides (13) ..........

31 Conbaculatisporites mesozoicus

32 Conbaculatisporites spinosus (24) .......

33 Vitreisporites pallidus (112) ............

34 Verrucosisporites klukiformis (33) .......

35 Camarozonisporites rudis (64) ..........

36 Rhaetipollis germanicus (95) ...........

37 Ischyosporites $\mathrm{sp}$. af.

I. crateris (40)

38 Densosporites cavernatus (50)

39 Cingulizonates of. inequalis (55)

40 Eucommiidites troedsoni (88)

41 Quadraeculina anellaeformis (1

42 Anapiculatisporites telephorous (32) .....

43 Corollina zwolinskai (92) ............

44 Polypodiisporites polymicroforatus

(35)

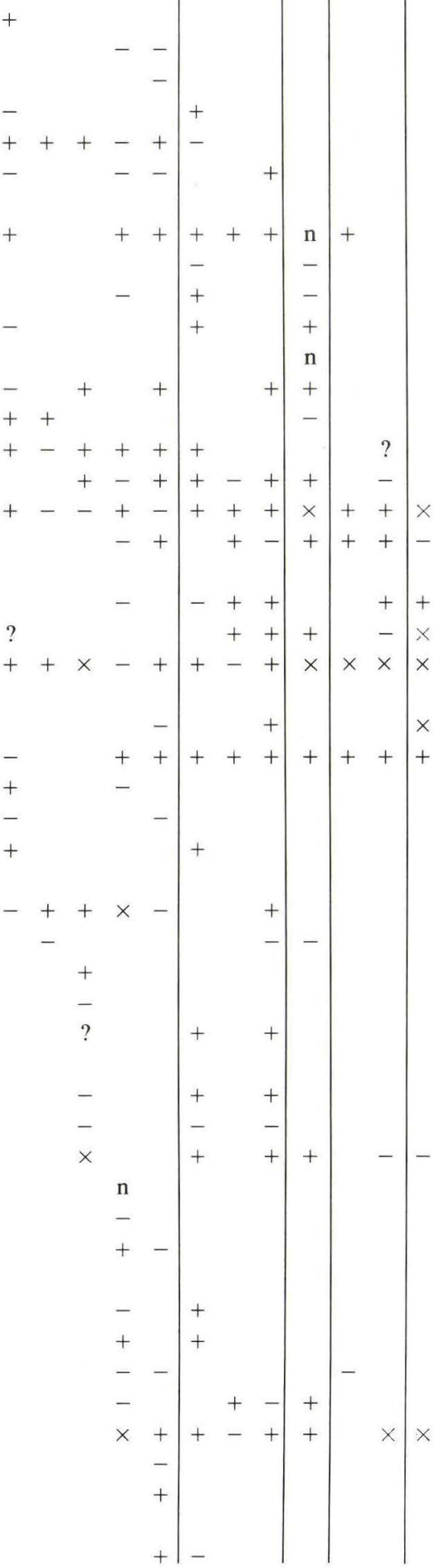


Vertical distribution of Palynomorphs in Scania

45 Semiretisporis gothae \& maljavkinae ( 57 \& 58)

46 Chasmatosporites elegans (78)

47 Schismatosporites ovalis (122)

48 Protopinus scanicus (111)

49 Neochomotriletes triangularis (47) .......

50 Lycopodiacidites rhaeticus (63)

51 Zebrasporites interscriptus (66)

52 Stereisporites cicatricosus (16)

53 Baculatisporites comaumensts (25) ......

54 Trachysporites fuscus (20) . .............

55 Lycopodiacidites rugulatus (62) ..........

56 Micrhystridium spp.

57 Stereisporites punctus (15)

58 Pinuspollenites pinoides (118) ...

59 Cerebropollenites thiergartii (102) ........

60 Alisporites radialis (116) ...............

61 Stereisporites antiquasporites (14) .......

62 Deltoidospora auritora (3) ...............

63 Contignisporites problematicus (46) .....

64 Trachysporites asper (21) ..............

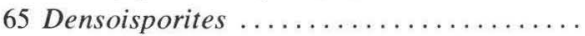

66 Chasmatosporites apertus (79)

67 Clavatipollenites hughesi (86)

68 Ovalipollis ovalis (104)

69 Cerebropollenites macroverrucosus (101)

70 Lycopodiumsporites semimuris (39) .....

71 "Pityosporites" neomundamus (119) .....

72 Anapiculatisporites spiniger (31) ........

73 Leiofusa jurassica (138)

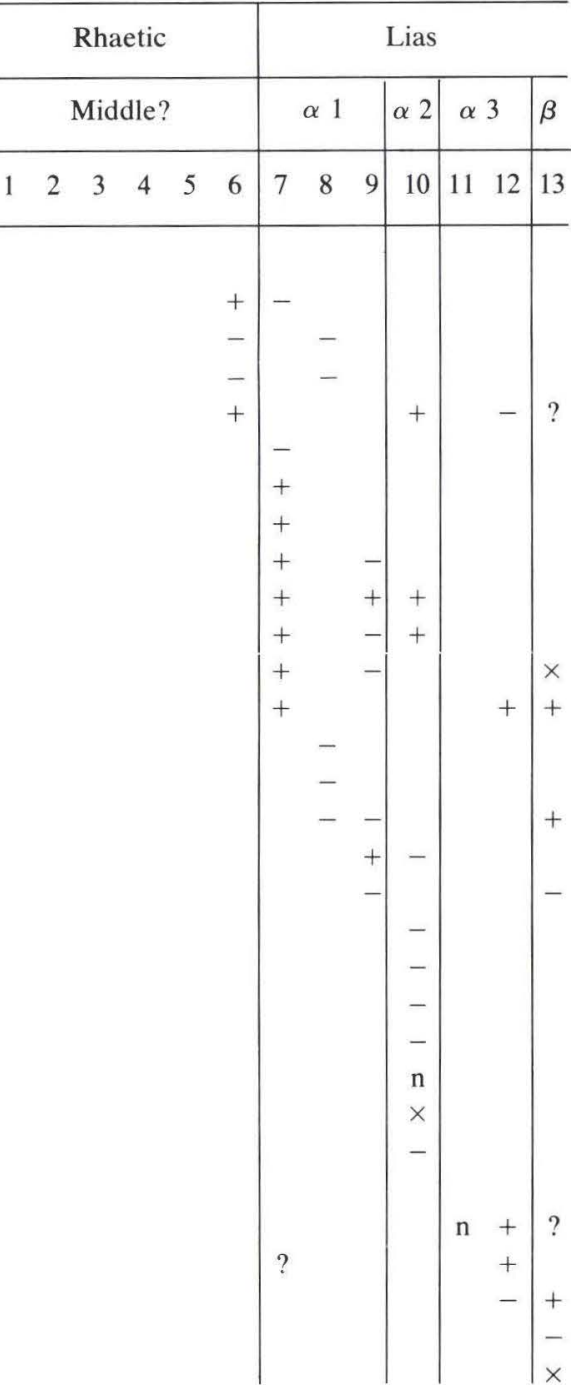




\section{Dansk sammendrag}

\section{Rhæt - nedre lias palynologi i det sydøstlige Nordsø Bassins landområder}

Rhætiske og nedre jurassiske aflejringer fra dybdeboringen Rødby 1 undersøges for indholdet af pollen, mikrosporer og aquatiske alger. Til sammenligning undersøges de samme fossilgrupper i jævnaldrende aflejringer fra daglokaliteter og boringer i NV Tyskland og Skåne.

Rødby 1 korreleres lithostratigrafisk med det nordvesttyske bækken, hovedsagelig på grundlag af lerfarverne (mørke i det basale lias, lysegrågrønlige til brune i øvre rhæt, næsten sorte i mellem rhæt og grønlige og røde i nedre rhæt).

Hovedsagelig på grundlag af den vertikale udbredelse af pollen og mikrosporer i Rødby 1, Skåne og de tyske dybdeboringer Eitzendorf 8 og Maasbüll 1 samt de fra Østtyskland (og Polen) kendte pollen og mikrospore floraer defineres 6 zoner og 3 sunzoner. Ved hjælp af disse zoner og subzoner korreleres rhæt til nedre lias aflejringerne i Rødby 1, Skåne, Polen og Østtyskland med de bedre daterede nordvesttyske aflejringer.

Den øverste del af lias afsnittet i Rødby 1 med prøverne $1560^{\prime}$ og $1561^{\prime}$ er formentlig af lias alfa 3 alder, omend en korrelation med den $\emptyset$ verste del af lias alfa 2 ikke helt kan udelukkes. Den øvrige del af lias afsnittet ned til 1839' er af lias alfa 1-2 alder. Afsnittet $1839^{\prime}-1859^{\prime}$ henføres til den øverste del af $\emptyset$ vre rhæt, omend der er en vis lighed med de skånske boserup lag, som henføres til den basale del af lias alfa 1. 1859'-1919' henføres til øvre rhæt, 1919'-2200' til mellem rhæt og 2200'-2349' til nedre rhæt. Det nordeuropæiske nedre rhæt skal muligvis henføres til norien; dette er dog afhængigt af, hvor rhætien norien grænsen lægges i det alpine område.

Den skånske aflejring, hvorpå den vigtige rhætiske mikrospore Limbosporites lundbladi Nilsson først blev beskrevet, vises at være af mellem rhætisk alder og ikke af nedre liassisk, som tidligere antaget.

De polske Drawno og Weilichowo aflejringer, der tidligere blev anset for at kunne korreleres med mellem og øvre rhæt i NV Tyskland, henføres til henholdsvis nedre rhæt og mellem (til øvre) rhæt.

I Polen og i Skåne mangler øvre rhæt formentlig, i det mindste delvis. 
I det systematiske afsnit behandles 147 systematiske grupper, hovedsagelig arter. En ny art Corrolina zwolinskai og 24 nye kombinationer af arter/ varianter foreslås. Bestemmelserne er i udstrakt grad baseret på forfatterens studier af type-materiale ved forskellige europæiske geologiske og botaniske institutioner. 


\section{References}

Balme, B. E. 1970: Palynology of Permian and Triassic strata in the Salt Range and Sugher Range West Pakistan. - In: Kummel (editor) Stratigraphic Boundary Problems: Permian and Triassic of West Pakistan. Dept. Geol. Univ. Kansas, Spec. publ. 4, pp. 305-455.

Bertelsen, F. \& Michelsen, O. 1970: Megaspores and Ostracodes from the Rhaeto-Liassic Section in Boring rødby 1, Southern Denmark. - Danm. geol. Unders. II Række, 94, 60 p.

Bharadwaj, D. C. \& Singh, H. P. 1964: An Upper Triassic miospore assemblage from the coals of Lunz (Austria). - The Paleobotanist, 12, 1, pp. 28-44.

Briche, P., Danze-Corsin, P. \& Laveine, J. P. 1963: Flore infraliasique du Boulonais (macro-et microflore). - Mem. Soc. Geol. Nord, 13, pp. 1-143.

Christensen, O. B. 1962: Ostracodtyper fra Keuper-Rhaet lagserien: dybdeboringerne ved Harte og Ullerslev. - Meddr dansk geol. Foren., 15, pp. 90-99.

Christensen, O. B. 1963: Ostracoder fra Keuper-Rhaet i nogle danske dybdeboringer. - Meddr geol. Foren. 15, p. 240.

Cookson, I. C. 1947: Plant Microfossils from the Lignites of Kerguelen Archipelago. B.A.N.Z. Antarctic Research Expedition 1929-1931, Reports-Ser. A. II, 8, pp. 127-142.

Cookson, I. C. 1953: Difference in microspore composition of some samples from a bore at Comaum, South Australia. - Austral. J. Bot., 1(3), pp. 462-473.

Cookson, I. C. \& Eisenack, A. 1958: Microplankton from Australian and New Guinea Upper Mesozoic sediments. - Proc. R. Soc. Vict., 70, pp. 19-79.

Cornet, B. \& Traverse, A. 1975: Palynological contributions to the chronology and stratigraphy of the Hartford Basin in Connecticut and Massachusetts. - Geoscience and Man, 11, pp. 1-33.

Couper, R. A. 1958: British Mesozoic microspores and pollen grains. A systematic and stratigraphic study. - Palaeontographica, Abt. B, 103(4-6), pp. 75-179.

Dadlez, R. 1964: Wyniki wiercenia Mechowo Ib I. Stratygrafia i przebieg sedymentacji kajpru i dolnej jury na profilu wiercenia Mechowo IG I. - Biul. Inst. Geol., 189, pp. 61-92.

Dadlez, R. 1967: The main evidence pointing to the Jurassic age of the epicontinental Rhaetian. - Biul. Inst. Geol., 203, pp. 42-44.

Dadlez, R. 1967: The main evidence pointing to the Jurassic age of the epicontinental RhaeWielkopolskim. - Kvart Geol. Inst., 1, pp. 131-155.

Deflandre, G. 1937: Microfossiles de silex crétacés II. Flagellés incertae sedis. Hystrichosphaeridées. Sarcodinés. Organismes divers. - Annls. Paléont. 26, pp. 51-103.

Dettmann, M. 1963: Upper Mesozoic microfloras from South-Eastern Australia. - Proc. Royal Soc. Victoria, New Ser., 77(1), $148 \mathrm{p}$

Döring, H. 1965: Die sporen-paläontologische Gliederung des Wealden in Westmecklenburg (Struktur Werle). - Geologie, 14(17), $118 \mathrm{p}$.

Downie, C. \& Sarjeant, W. A. S. 1963: On the interpretation and status of some hystrichosphere genera. - Palaeontology, 6(1), pp. 83-86.

Dybova, S. \& Jachowicz, A. 1957: Microspores of the Upper Silesian Coal Measures. - Prace Inst. Geol. Warsz., 23, pp. 1-328. 
Erdtman, G. 1948: Did Dicotyledonous Plants exist in Early Jurassic Times? - Geol. Fören. Stockholm Förh. 70, pp. 265-271.

Fisher, M. J. 1972: Rhaeto Liassic palynomorphs from the Barnstone Railway Cutting Nottinghamshire. - Mercian Geologist, 4, pp. 101-106.

Grodzicka-Szymanko, W. \& Orlowska-Zwolinska, T. 1972: Stratigraphy of the Upper Triassic in the NE margin of the Upper Silesian Coal Basin. - Kwart. Geol., 16, 1, pp. 216-232.

Harris, T. M. 1931: The fossil flora of Scoresby Sound East Greenland. Part 1: Cryptogams (exclusive of Lycopodiales). - Meddr Grønl., 85, 104 p.

Harris, T. M. 1937: The fossil flora of Scoresby Sound East Greenland. Part 5. Stratigraphic relations of the plant beds. - Meddr Grønl., 112, $114 \mathrm{p}$.

Harris, T. M. 1957: A Liasso-Rhaetic flora in South Wales. - Proceeding of the Royal Society of London, B, 147, pp. 289-308.

Herngreen, G. F. W. \& de Boer, K. F. 1974: Palynology of Rhaetian, Liassic and Dogger Strata in the Eastern Netherlands. - Geol. en Mijnbouw. 53(6), pp. 343-368.

Hiltmann, W. 1967: Über die Sporenführung des Kernprofiles der Bohrung Contern FG 11. Publ. Serv. Geol. Luxemb., 17, pp. 137-206.

Hoffmann, K. 1963: Die Verbreitung primärbitumunöser Gesteine im Westdeutschen Lias. Erdöl u. Kohle, 16(7), pp. 741-747.

Hope, R. C. \& Schulz, G. 1973: Late Triassic microfossil flora from the Deep River Basin, North Carolina. - Palaeontographica, B, 141, pp. 63-88.

Iljina, V. J. 1971: Palynological characteristic of the Jurassic deposits of Siberia. - In: Mesozoic microfossils of Siberia and Far East, III-d Int. Conf. Palynol. in Novosibirsk 1971, pp. 6-51. (In Russian).

Jansonius, J. 1962: Palynology of Permian and Triassic Sediments, Peace River area, Western Canada. - Palaeontographica, 110 B, pp. 35-98.

Jansonius, J. 1971: Emended diagnosis of Alisporites Daugherty 1941. - Pollen et Spores, 13(2), pp. 349-357.

Jersey, N. J. de \& Paten, R. J. 1964: Jurassic spores and pollen grains from the Surat Basin. Geol. Surv. Queensl., 322, 18 p.

Jux, U. 1968: Torfe des rheinischen Tertiärs in Vergleich mit heutigen Bildungen an der amerikanischen Ostküste. - Deut. geol. Ges., 118, pp. 69-101.

Kedves, M. \& Simoncsics, P. 1964: Spores nouvelles extraites de minerai de manganese jurassique de la region d'Urhut (Hongrie). - Pollen et Spores, 6(2), pp. 605-610.

Kemp, E. M. 1970: Aptian and Albian Miospores from southern England. - Palaeontographica, B, 131, pp. 73-143.

Klaus, W. 1960: Sporen der karnischen Stuffe der ostalpinen Trias. - Jb. Geol. B. A., Sonderbd. 5, pp. 107-183.

Kölbel, H. 1967: Die Palaeogeographie des Juras im Nordteil der DDR in Beziehung zu den Nachbargebieten. - Ber. deutsch. Ges. Geol. Wis., A. Geol. u. Paläont., 12(3A), 259 p.

Kopik, J. 1967: The boundary between the epicontinental Triassic and Jurassic deposits in Poland. - Biul. Inst. Geol., 203, pp. 25-36.

Kozur, H. 1972: Vorläufige Mitteilung zur Parallelisierung der germanischen und tethyalen Trias sowie einige Bemerkungen zur Stufen und Unterstufengliederung der Trias. - Mitt. Ges. Geol. Bergbaustud., 21(I), pp. 361-412.

Krutzsch, W. 1955: Über einige liassische und angiospermide Sporomorphen. - Geologi, 4(1), pp. 65-76.

Krutzsch, W. 1959: Mikropaläontologische (sporenpaläontologische) Untersuchungen in der Braunkohle des Geiseltales. - Geologie, 8(21-22), 425 p. 
Krutzsch, W. 1963: atlas der mittel- und jungteriären Sporen- und Pollen- sowie der Mikroplanktonformen des nördlichen Mitteleuropas. - Lief. III, 128 p.

Krutzsch, W. 1967: Atlas der mittel- und jungtertiären Sporen- und Pollen- sowie der Mikroplanktonformen des nördlichen Mitteleuropas. - Lief. IV/V, 232 p.

Larsen, G. 1966: Rhaetic-Jurassic-Lower Cretaceous Sediments in the Danish Embayment. Danm. geol. Unders., II Række, 9, 127 p.

Lund, J. J. 1975: Palynostratigraphie des Oberen Keuper und Unteren Lias von NWDeutschland und seinen Nachbargebieten. - Compendium 75/76, Ergänzungsb. Erdöl und Kohle, Erdgas, Petr, vere. m. Brennstoffch., pp. 140-148.

Lund, J. J. 1976: Palynostratigraphie des Oberen Keuper und Unteren Lias von NWDeutschland und seinen Nachbargebieten. - Erdöl und Kohle, Erdgas, Petr. vere. m. Brennstoffch., 29(3), p. 123.

Lundblad, A. B. 1950: Studies in the Rhaeto-Liassic Floras of Sweden. I. Pteridophyta, Pteridospermae, and Cycadophyta from the Mining District of NW Scania. - Kungl Svenska Vet.-akad. Handl., Fjärde Ser., 1(8), 82 p.

Lundblad, A. B. 1954: Liassic coal-mines of Skromberga (Prov. of Scania), Sweden. - Sv. Bot. Tidskr., 48(2), pp. 381-417.

Mädler, K. 1964a: Bemerkungswerte Sporenformen aus dem Keuper unteren Lias. - Fortsch. Geol. Rheinl. Westf., 12, pp. 169-200.

Mädler, K. 1964b: Die geologische Verbreitung von Sporen und Pollen in der deutschen Trias. - Beih. geol. Jb., 65, 147 p.

Mädler, K. 1968: Die figurierten organische Bestandteile der Posidonienschiefers. - Beih. geol. Jb., 58, pp. 287-406.

Maljavkina, V. S. 1949: Diagnose der Sporen und Pollen von Jura und Kreide. - Trudy VNIGRI, 33, $137 \mathrm{p}$.

Marcinkiewicz, T. 1971: Stratygrafia retyku i liasu w Polsce na podstawie badan megasporowych. - Pr. Inst. Geol., T. 65, 37 p.

Michelsen, O. 1973: On Liassic holothurian and ostracod assemblages from the Danish embayment. - Danm. geol. Unders., Årbog 1972, pp. 49-68.

Morbey, S. J. 1975: The palynostratigraphy of the Rhaetian stage, Upper Triassic in the Kendelbachgraben, Austria. - Palaeontographica, B, 152(1-3), pp. 1-75.

Nathorst, A. G. 1878: Om floraen i Skånes Kolförande bildningar. II Floran vid Höganäs Helsingborg. - S.G.U. Sv. C., 29, 53 p.

Nilsson, T. 1958: Über das Vorkommen eines mesozoischen Sapropelgesteins in Schonen. Lunds Univ. Årsskrift, N. F. Avd. 2, 54(10), 112 p.

Norris, G. 1965: Triassic and Jurassic miospores and acritarchs from the Beacon and Ferrar Groups, Victoria Land, Antarctica. - New Zeal. Journl. Geol. Geophys., 8, pp. 236-277.

Orbell, G. 1973: Palynology of the British Rhaeto-Liassic. - Bull. Geol. Surv. Gr. Britain, 44, pp. 1-44.

Orlowska-Zwolinska, T. 1966: Lower Liassic age of the Wielichowo beds in the light of sporeand pollen analysis (Polish Lowland). - Kwart. Geol. Inst. Warsz., 10(4), pp. 1001-1022.

Orlowska-Zwolinska, T. 1967: Microfloristic criteria for age determination of the beds occurring at the Triassic-Jurassic boundary in the Extra-Carpathian areas of Poland. - Biul Inst. Geol., 203, pp. 52-55.

Orlowska-Zwolinska, T. 1971: On several stratigraphically important species of sporomorphs occurring in the Keuper of Poland. - Acta. Soc. Bot. Pol., 40(4), pp. 633-651.

Orlowska-Zwolinska, T. 1972: Stratigraphy of Keuper deposits from bore hole Boza Wola on basis of spore- and pollen-analysis. - Kwart. Geol. Inst. Warsz., 16(2), pp. 301-313. 
Pautsch, M. E. 1958: Keuper sporomorphs from Swierczyna, Poland. - Micropaleont., 4(3), pp. 321-325.

Pflug, H. D. 1953: Zur Entstehung und Entwicklung des Angiospermiden Pollen in der Erdgeschichte. - Palaeontographica, Abt. B. 95(4-6), pp. 60-171.

Playford, G. 1965: Plant microfossils from Triassic sediments near Poatina, Tasmania. - Jour. Geol. Soc. Australia, 12, pp. 173-210.

Playford, G. \& Dettmann, M. E. 1965: Rhaeto-Liassic plant microfossils from the Leigh Creek Coal Mesures, South Australia. - Senkenbergiana leth., 46, pp. 127-181.

Pocock, S. A. J. 1970: Palynology of the Jurassic sediments of Western Canada. Part I. Terrestial species. - Palaeontographica, 130, pp. 12-72 \& 73-136.

Pocock, S. A. J. \& Jansonius, J. 1961: The Pollen genus Classopollis Pflug 1953. - Micropaleontology, 7(4), pp. 439-449.

Potonié, R. 1956-1970: Synopsis der Gattungen der Sporae dispersae. Teil I-V. - Beih. geol. Jb., $23,31,39,72 \& 87$.

Potonié, R. \& Kremp, G. 1954: Die Gattungen der paläozoischen Sporae dispersae und ihre Stratigraphie. - Geol. Jb., 69, pp. 111-194.

Potonié, R. \& Kremp, G. 1955-1956a/b: Die Sporae dispersae des Ruhrkarbons, ihre Morphographie und Stratigraphie mit Ausblicken auf Arten anderer Gebiete und Zeitabschnitte. 1.Palaeontographica, 98, pp. 1-136. II. - Palaeontographica, 99, pp. 85-191. III. - Palaeontographica, 100, pp. 65-121.

Potonié, R. \& Venitz, H. 1934: Zur Mikrobotanik des miozänen Humodils der niederrheinischen Bucht. - Arb. Inst. Paläobot. Petrogr. Brennsteine, 5, pp. 5-54.

Reinhardt, P. 1961: Sporae dispersae aus dem Rhät Thüringens. - Mber. deutsch. Akad. Wiss. Berlin, 3(11/12), pp. 704-711.

Reinhardt, P. 1964: Über die Sporae dispersae der Thüringer Trias. - Mber. deutsch. Akad. Wiss. Berlin, 6(1), pp. 46-56.

Reissinger, A. 1950: Die "Pollenanalyse" ausgedehnt auf alle Sedimentgesteine, der geologischen Vergangenheit. - Palaeontographica, Abt. B, 90(4-6), pp. 99-126.

Reyment, R. A. 1969: Upper Sinemurian (Lias) at Gantofta Skåne. - Geol. För. Stockh. Förh., 91, pp. 208-216.

Reyre, Y. 1970: Stereoscan observations on the pollen genus Classopollis Pflug 1953. - Palaeontology, 13, pp. 303-322.

Rioult, M. \& Levet-Carette, J. 1965: Microflore infraliasique du Cotentin. - Soc. Geol. Nord., Ann., 85(3), pp. 283-299.

Rogalska, M. 1954: Spore and pollen analysis of the Liassic coal of Blanowice in Upper Silesia. Inst. Geol. Warsz. Bull., 89, pp. 1-46.

Rogalska, M. 1956: Spore and pollen analysis of the Liassic deposits of the Mroczkow-Rozwady area in the Opoczno district. - Inst. Geol. Warsz. Bull., 104, pp. 1-89.

Rogalska, M. 1962: Spores and pollen grain analysis of Jurassic sediments of the northern part of the Cracow Wielund Cuesta. - Inst. Geol. Warsz. Prace, 30, pp. 495-524.

Ross, N. E. 1949: On a Cretaceous pollen and spore bearing clay deposit of Scania. - Bill. Geol. Inst. Uppsala, 34, pp. 25-43.

Rusitzka, D. 1967: Paläogeographie der Trias im Nordteil der DDR. - Ber. deutsch. Ges. Geol. Wiss., A Geol. u. Pal., 12(3/4), pp. 243-257.

Sarjeant, W. A. S. 1967: Observations on the acritarch genus "Micrhystridium" Deflandre. Rev. Micropaleontologie, 9(4), pp. 201-208.

Schaarschmidt, F. 1963: Sporen und Hystrichosphaerideen aus dem Zechstein von Büdingen in der Wetterau. - Palaeontographica, B, 113, pp. 38-91. 
Scheuring, B.W. 1970: Palynologische und palynostratigraphische Untersuchungen des Keuper im Bölchentunnel (Solothurner Jura). - Schweiz. paläont. Abh., 88, 119 p.

Scheuring, B. W. 1974: Krauseleisporites. - Rev. Paleobot. Palynol., 17, pp. 187-203.

Schott, N. 1942: Die Gliederung im nordwestdeutschen Rätbecken. - Ber. Reichsamt Bodenforsch. f. 1942, pp. 61-77.

Schulz, E. 1962: Sporenpaläontologische Untersuchungen zur Rhät Lias - Grenze im Thüringen der Altmark. - Geologie, 11(3), pp. 308-319.

Schulz, E. 1967: Sporenpaläontologische Untersuchungen rätoliassischer Schichten im Zentralteil des Germanischen Beckens. - Paläont. Abh., B, 2(3), pp. 541-633.

Schulz, E. \& Krutzsch, W. 1961: Eichinitosporites iliacoides nov. fgen. et fsp. eine neue Sporenform aus dem Keuper der Niederlausitz. - Geologie, 32, pp. 122-127.

Schulz, E. \& Mai, 1966: Erläuterungen zur Tabelle der stratigraphischen Verbreitung des Phytoplanktons im Lias und Dogger. - Abh. zentr. geol. Inst., 8, pp. 21-34.

Schumacher, K. H. \& Sonntag, H. 1964: Zur Stratigraphie und Ausbildung des Lias im Norden der Deutschen Demokratischen Republik. - Geologie, Jhg. 13, 3, pp. 303-315.

Seidel, G. 1965: Zur geologischen Entwicklungsgeschichte des Thüringer Beckens. - Geologie, Jhg. 14, Beiheft 50, $115 \mathrm{p}$.

Seitz, O. \& Wicker, C. A. 1950: Über die im Bereich Tempelburger Struktur gestossenen Tiefbohrungen und ihre Bedeutung für die Stratigraphie und Paläogeographie der Trias. Geol. Jb., 65, pp. 463-496.

Singh, H. P. 1964: A miospore assemblage from the Permian of Iraq. - Palaeont., 7(2), pp. 240-265.

Smith, A. H. V. 1971: Genus Verrucosisporites Ibrahim 1933 emend. - Publ. Comm. Int. Microflore Paléoz., 4, pp. 35-86.

Sorgenfrei, Th. \& Buch. A. 1964: Deep Tests in Denmark 1935-1959. - D.G.U. III Række, 36, $146 \mathrm{p}$.

Thiergart, F. 1949: Der stratigraphische Wert mesozoischer Pollen und Sporen. - Palaeontographica, Abt. B, 89, pp. 1-34.

Thomson, P. W. \& Pflug, H. 1953: Pollen und Sporen des mitteleuropäischen Tertiärs. Palaeontographica, Abt. b, 94(1-4), 138 p.

Tralau, H. 1968: Botanical investigations into the fossil flora of Eriksdal in Fyledalen, Scania. II. The Middle Jurassic Microflora. - Geol. Surv. Swed., C, 633, pp. 1-132.

Tralau, H. 1975: An Upper Triassic microflora from Vallåkra, Southern Sweden. - Geol. Fören. Förh. Stockh., 97(562), pp. 237-242.

Troedson, G. 1951: On the Höganäs Serias of Sweden (Rhaeto-Lias). - Lunds Univ. Årsskrift N.F. Ava. 2, 47(1), 269 p.

Urlicks, M. 1972: Ostracoden aus den Kössener Schichten und ihr Abhängigkeit von der Ökologie. - Mitt. Ges. Geol. Bergbaustud. 21, II., pp. 661-710.

Venkatachala, B. S. \& Góczán, F. 1964: The spore-pollen flora of the Hungarian "Kössen facies". - Acta Geol. Acad. Scient. Hung., 8, pp. 203-228.

Wall, D. 1965: Microplancton, pollen and spores from the Lower Jurassic in Britain. - Micropaleont., 11(2), pp. 151-190.

Wicher, C. A. 1957: Die mikropaläontologische Gliederung des nichtmarinen Keuper. - Erdöl und Kohle, 10. Jahrg., 1, pp. 3-7.

Wiedmann, J. 1972: Ammoniten-Nuklei aus Schlämmproben der nordalpinen Obertrias - ihre Stammesgeschichte und stratigraphische Bedeutung. - Mitt. Ges. Geol. Bergbaustud., 21(II), pp. 561-622.

Wienholz, R. 1960: Das Keuperprofil an der Struktur Marnitz. - Z. angew. Geol., 6(9), pp. 434-435. 
Will, H. J. 1969: Untersuchungen zur Stratigraphie und Genese des Oberkeupers in Nordwestdeutschland. - Beih. geol. Jb., 54, 240 p.

Wilson, L. R. \& Webster, R. M. 1946: Plant microfossils from a Fort Union Coal of Montana. Amer. J. Bot., 35(4), pp. 271-278.

Wodehouse, R. P. 1935: Pollen Grains. - McGraw-Hill, New York 1959: Hafner, New York, 574 p. 


\section{Plates}

X 500 except otherwise stated. All photos are from unretuched negatives.

When one specimen is shown by two figures ( $\&$ b), then figure a shows a higher focus than figure $b$.

$\mathrm{Sg}$. refers to single grain slides.

Gg. refers to slides with "fished" specimens of a single type.

Pg. refers to slides with "fished" specimens of several types.

$1 \mathrm{~s} 2$ refers to strew slides (second slide of the first preparation of the sample under consideration).

The slides with the illustrated specimens are deposited at the Geological Institute, University of Århus, Denmark. 


\section{Plate 1}

Fig. 1: Deltoidospora toralis var. media (1b.). R $1859 \mathrm{Sg} .7$.

Figs. 2a-b \& 3a-b: Deltoidospora toralis (1.). Fig. 2a-b: R 1843 SEM-slide C. fig. 2a photographed in water $\times 500$, fig. $2 b$, scanning micrograph of same specimen $\times 1000$. Fig. 3a-b: R 1721 Sg. 12.

Figs. 4a-b: Deltoidospora crassexina (4.). R $1561 \mathrm{Sg} .22$.

Figs. 5a-b: Deltoidospora auritora (3.). R 1843 Sg. 22.

Fig. 6: Deltoidospora minor (2.). R 1561 1s4.

Figs. 7a-b: Deltoidospora sp. (5.). R 1843 SEM-slide C, fig. 7a photographed in water $\times 500$, fig. $7 \mathrm{~b}$, scanning micrograph of same specimen $\times 1000$.

Fig. 8: Intrapunctisporis toralis (6.). R 1862 Sg. 6.

Fig. 9: Intrapunctisporis hians (7.). R 1674 Sg. 3.

Fig. 10: Punctatisporites major (8.). R $1843 \mathrm{Sg} .24$.

Fig. 11: Punctatisporites globosus (9.). R 1674 Sg. 11.

Fig. 12: "Todisporites" cf. cinctus (10.). R $2326 \mathrm{Sg} .42$

Fig. 13: Retusotriletes mesozoicus (11.). R 1843 Sg. 30.

Fig. 14: Calamospora tener (12.). R 1862 Sg. 5. 

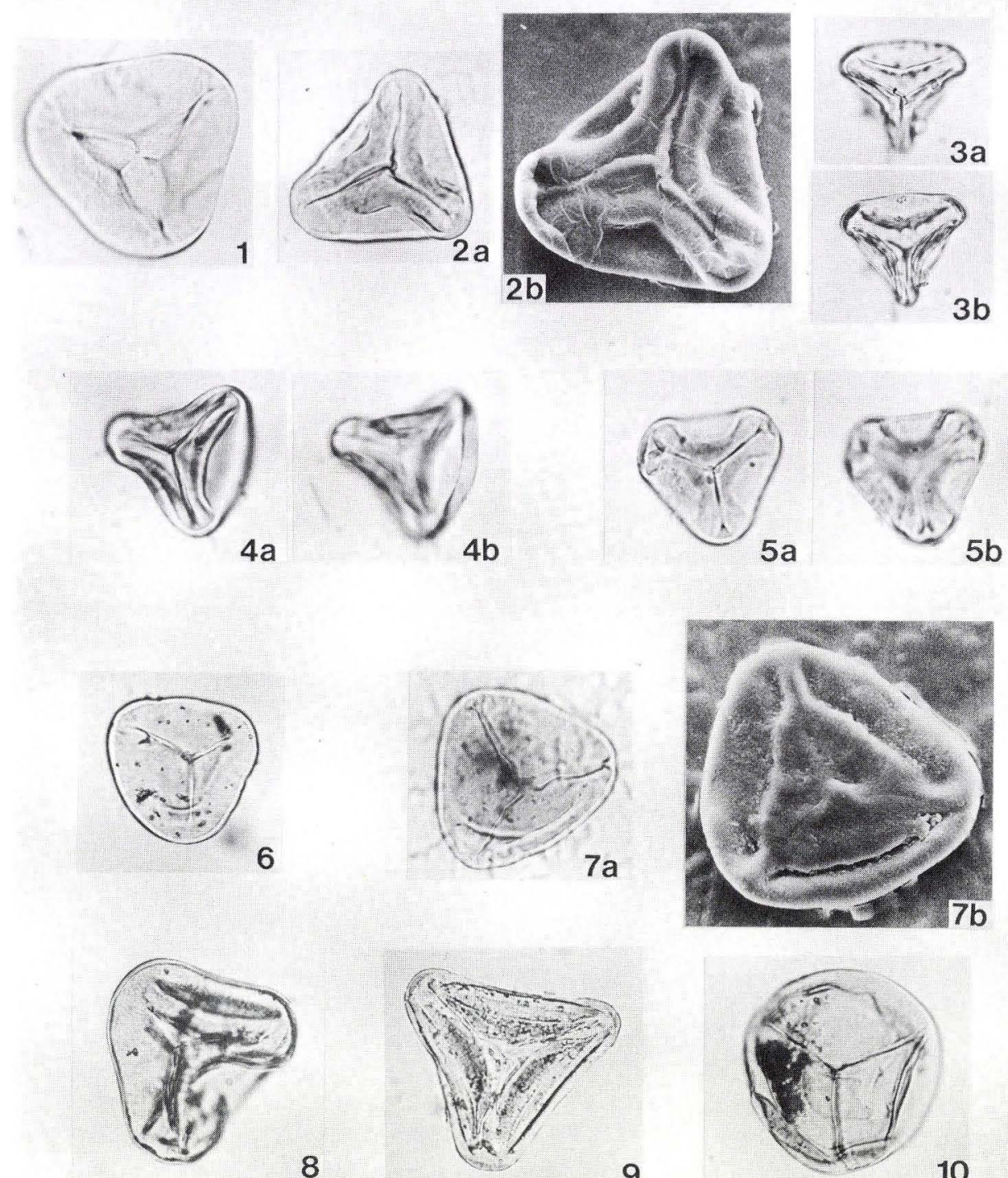

8
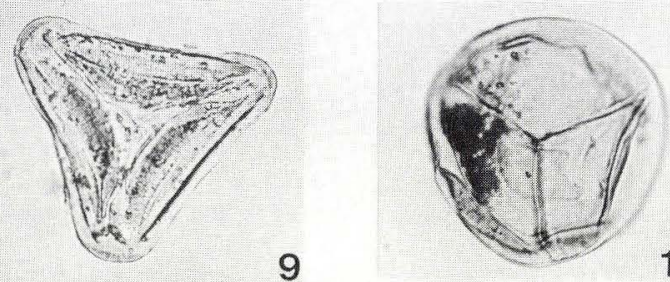

9

10
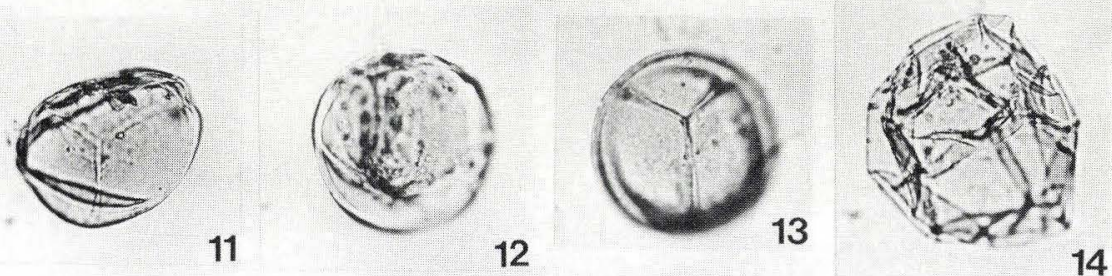
Plate 2

Fig. 1: Stereisporites stereoides (13.). R 1839 Sg. 15.

Figs. 2 \& 3: Stereisporites punctus (15.). Fig. 2: R 1843 Sg. 35. Fig. 3: R 1843 1s4 (specimen with radial grooves).

Fig. 4: Stereisporites cicatricosus (16.). R 1792 Sg. 4.

Fig. 5: Stereisporites cf. lunaris (17.). R 1843 Sg. 14.

Fig. 6: Foraminisporis jurassicus (19.). R 1839 Sg. 16.

Fig. 7: Trachysporites fuscus (20.). R $1561 \mathrm{Sg} .31$.

Fig. 8: Trachysporites asper (21.). R 1561 Sg. 36.

Fig. 9: Trachysporites cf. sparsus (22.). R 1560 Sg. 20.

Figs. 10a-b: Conbaculatisporites mesozoicus (23.). R 1843 SEM-slide C, fig. 10a photographed in water $\times 500$, fig. $10 \mathrm{~b}$, scanning micrograph of same specimen $\times 1000$.

Figs. 11a-b: Conbaculatisporites spinosus (24.). R $1561 \mathrm{Sg} .37$.

Figs. 12a-b: Baculatisporites comaumensis (25.). R 1839 Sg. 39.

Figs. 13a-b: Baculatisporites wellmani (26.). R 1839 Sg. 8.

Figs. 14a-b: Apiculatisporis ovalis (28.). R 1981 Sg. 9.

Figs. 15a-b: Baculatisporites opressus (27.). R 1888 Sg. 11.

Fig. 16: Apiculatisporis parvispinosus (29.). R $1843 \mathrm{Sg} .40$. 

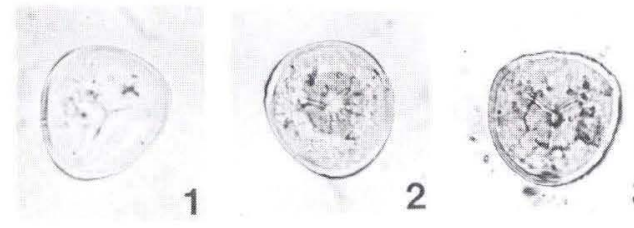

$3 \times 4$
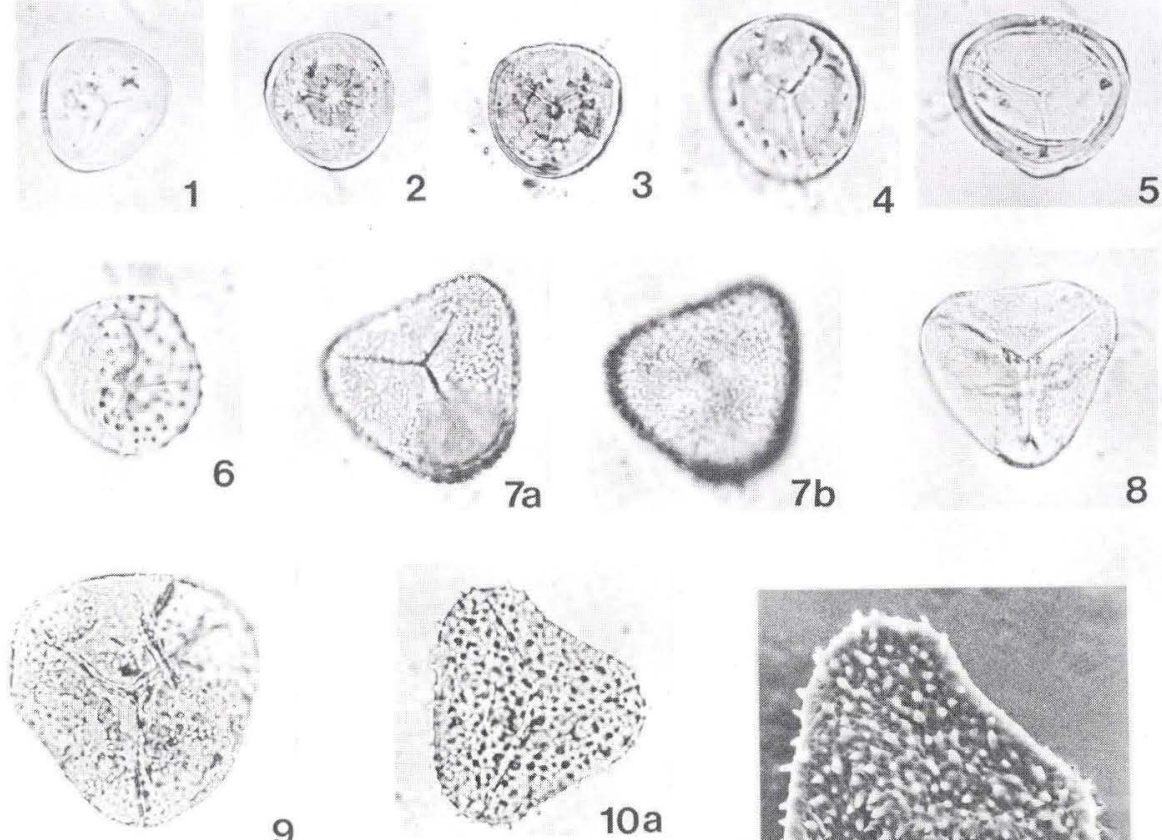

9
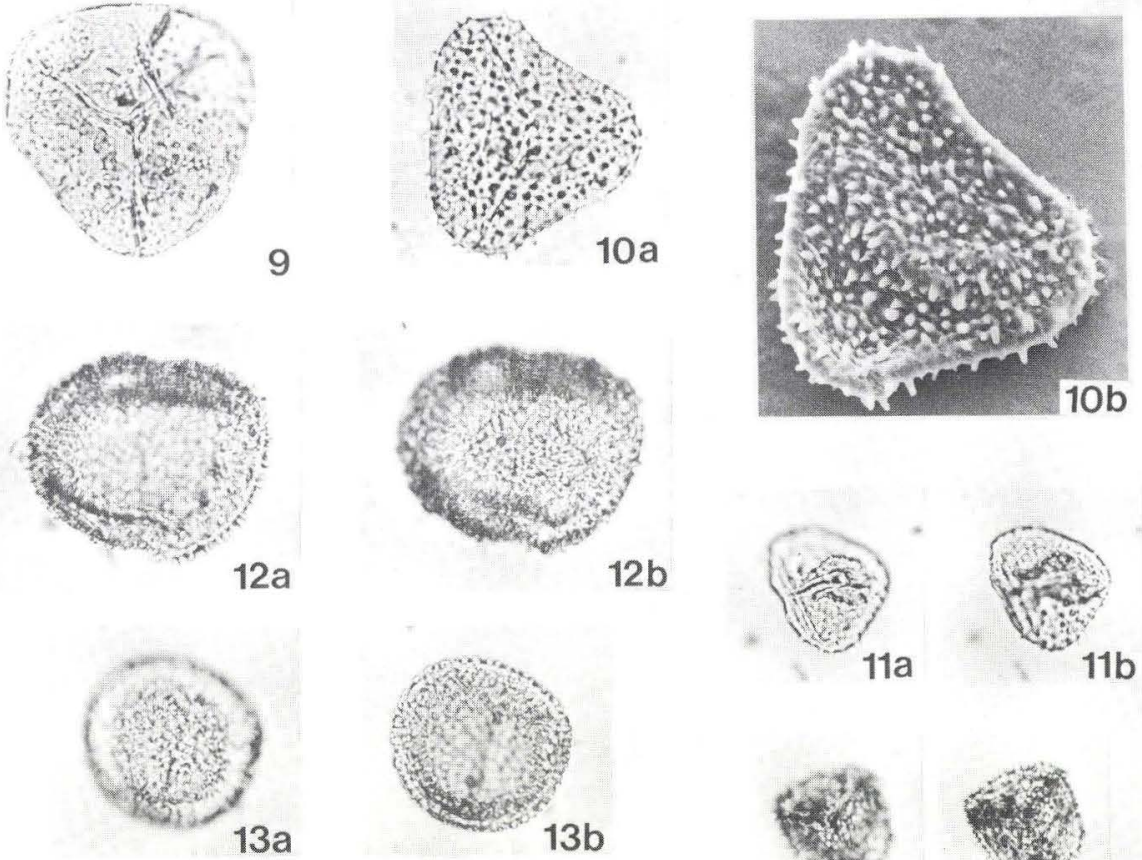

$13 a$
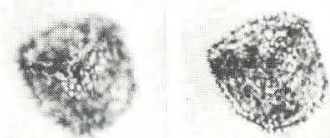

$15 a$

$15 b$
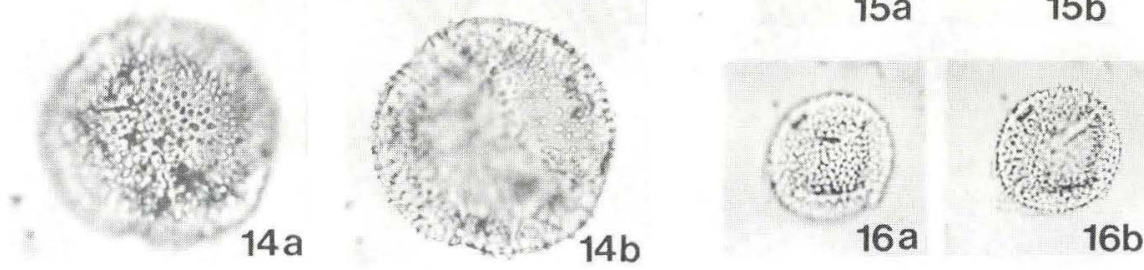

$16 \mathrm{~b}$ 


\section{Plate 3}

Figs. 1a-b: Porcellispora longdonensis (30.). R 2345 Sg. 1.

Fig. 2: Anapiculatisporites spiniger (31.). R $18434 \mathrm{~s} 3$.

Fig. 3: Anapiculatisporites telephorous (32.). R $1561 \mathrm{Sg} .14$.

Fig. 4: Verrucosisporites klukiformis (33.). R 1843 Sg. 44.

Fig. 5: Verrucosisporites sp. (34.). R $1861 \mathrm{Sg} .2$.

Figs. 6a-b: Polypodiisporites polymicroforatus (35.). R $1842 \mathrm{Sg} .1$.

Fig. 7: Polypodiisporites ipsviciensis (36.). R $1981 \mathrm{Sg} .6$.

Fig. 8: Cyclogranisporites areonosus (37.). R $1561 \mathrm{Sg} .42$.

Fig. 9: Ischyosporites sp. af. I. crateris (40.). R $1859 \mathrm{Sg} .5$.

Figs. 10a-b: Lycopodiumsporites austroclavatidites (38.). R 1561 Sg. 29.

Figs. 11a-b: Lycopodiumsporites semimuris (39.). R $1560 \mathrm{Sg} .8$.

Fig. 12: Iraquispora laevigata (41.). R $1888 \mathrm{Sg} .2$.

Figs. 13a-b: Iraquispora speciosa (42.). R $1888 \mathrm{Sg} .21$.

Figs. 14a-b: Uvaesporites reissingeri (43,). R 1839 Sg. 20.

Figs. 15a-b: Tetraed of Uvaesporites sp. (44.). R $1560 \mathrm{Sg} .46$. 

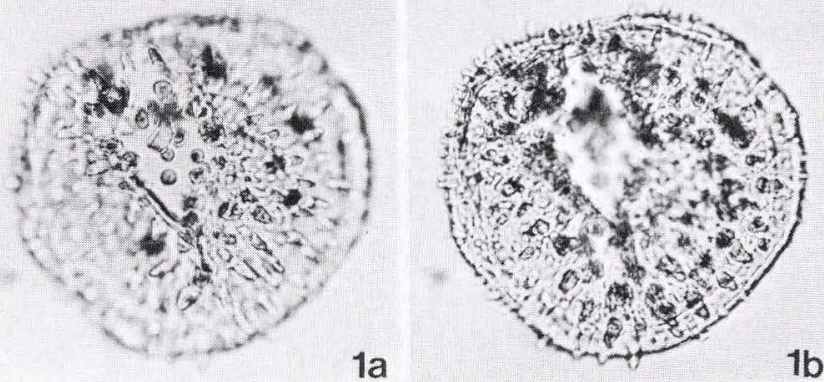

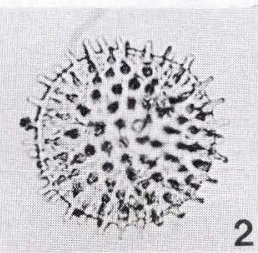

2

$1 b$

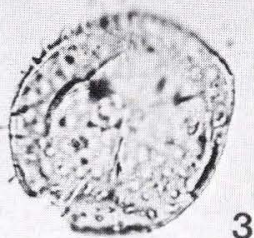

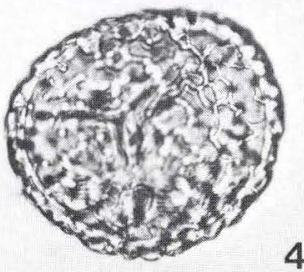
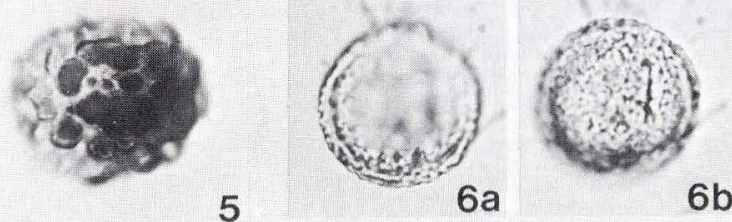

4

5
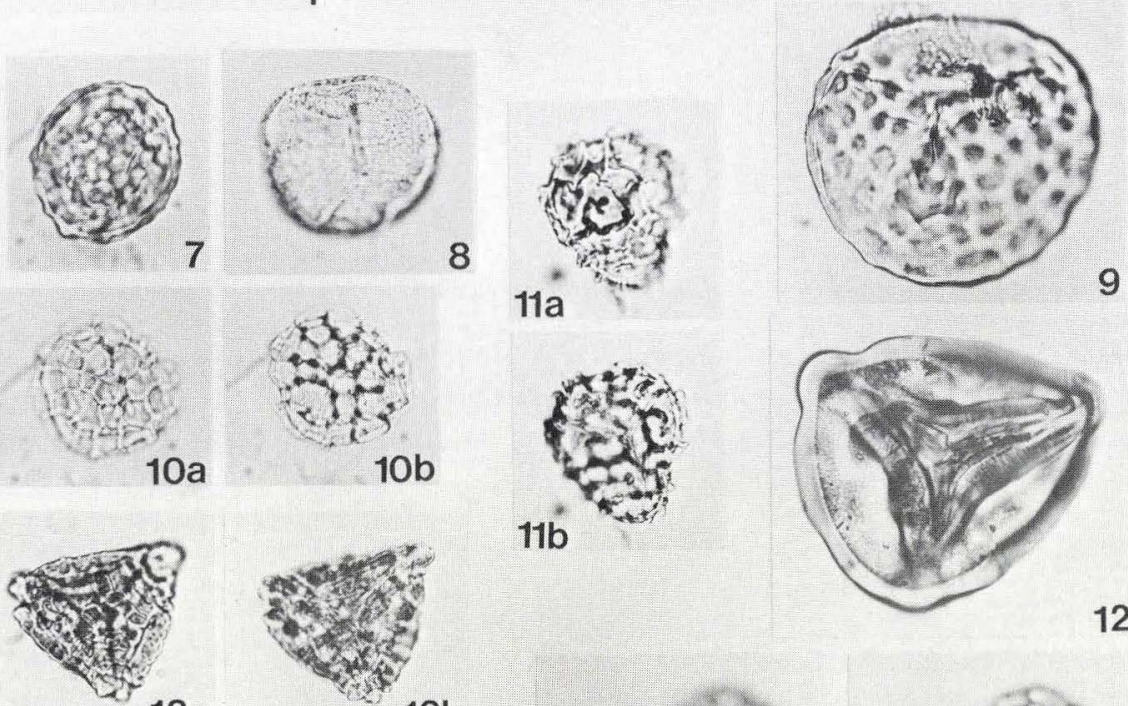

$13 a$
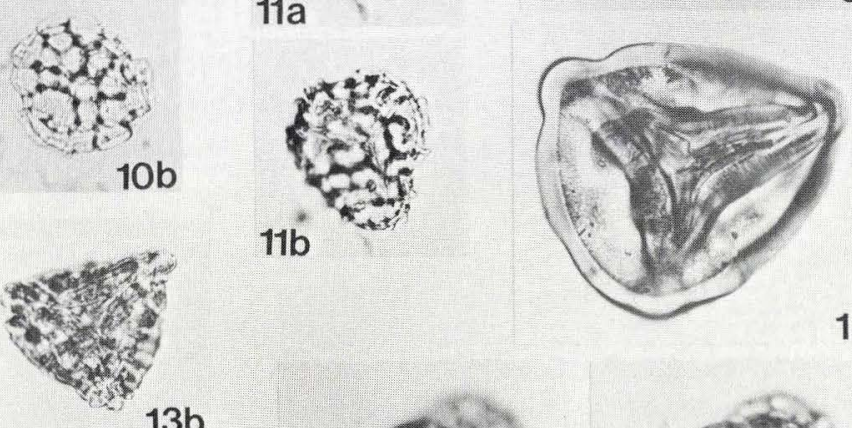

12
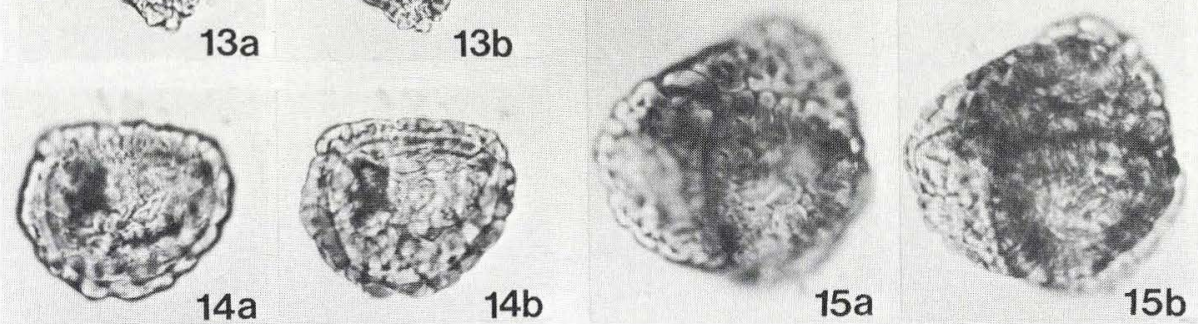


\section{Plate 4}

Figs. 1a-b: Uvaesporites sanguinolentiformis (45.). R $1561 \mathrm{Sg} .25$.

Figs. 2a-b: Contignisporites problematicus (46.). R $1843 \mathrm{Sg} .21$.

Fig. 3: Neochometriletes triangularis (47.). R $18436 \mathrm{~s} 3$.

Figs. 4a-b: Lycospora sp. (48.). R $1888 \mathrm{Sg} .18$.

Fig. 5: Densosporites fissus (49.). R 1842 Sg. 9.

Fig. 6: Densosporites cavernatus (50.). R $1930 \mathrm{Sg} .13$.

Fig. 7: Densosporites irregularis (51.). R 1561 fig. 16.

Figs.8a-b\&9a-b:Densosporites cf.cerebralis (52.). Fig.8a-b: R 1930Sg.54. Fig.9a-b: R1843Sg.6.

Fig. 10: Cingulizonates rhaeticus (53.). R 1843 Sg. 18.

Fig. 11: Cingulizonates marginatus (54.). R 1843 Sg. 42.

Figs. 12a-b: Semiretisporis cf. gothae (57.). R $1930 \mathrm{Sg} .17$. 

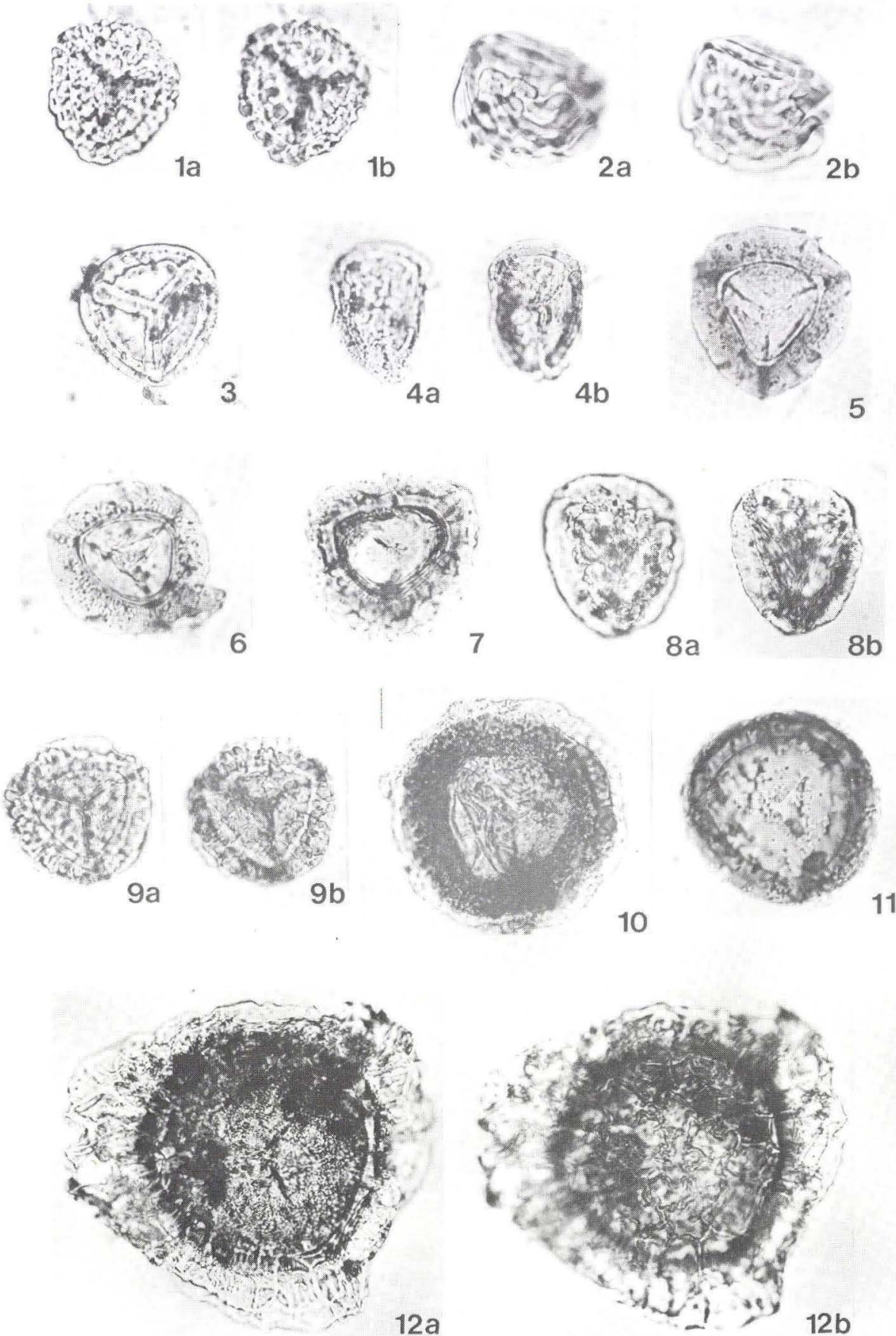


\section{Plate 5}

Figs. 1a-b: Cingulizonates cf. inequalis (55.). R $1888 \mathrm{Sg}$. 5. Fig. 1b same specimen as 1a but tilted with horizontal polar axis.

Figs. 2 \& 3: Limbosporites lundbladi (56.). Fig. 2: R 1839 Sg. 43. Fig. 3: R 1843 Sg. 33.

Fig. 4: Heliosporites altmarkensis (59.). R $1721 \mathrm{Sg} .8$.

Figs. 5a-b: Perotriletes globosus (60.). R 1674 Sg. 1.

Fig. 6: Perinosporites thuringiacus (61.). R $1930 \mathrm{Sg} .4$.

Fig. 7: Camarozonosporites rudis (64.). R $1930 \mathrm{Sg} .39$.

Fig. 8: Lycopodiacidites rugulatus (62.). R $1842 \mathrm{Sg} .12$.

Fig. 9: Lycopodiacidites rhaeticus (63.). R 1843 Sg. 31.

Fig. 10: Camarozonosporites laevigatus (65.). R $1930 \mathrm{Sg} .9$.

Fig. 11: Zebrasporites interscriptus (66.). R 1839 Sg. 9.

Fig. 12: Zebrasporites laevigatus (67.). R $1930 \mathrm{Sg} .12$.

Figs. 13a-b: Trigrisporites microrugulatus (68.). R 1888 Sg. 7.

Fig. 14: Tripartites mesozoicus (69.). R. 1930 Sg. 40.

Fig. 15: Triancoraesporites reticulatus (70.). R 1888 Sg. 29.

Fig. 16: Triancoraesporites ancorae (71.). R. $19606 s 5$.

Fig. 17: ? Conrutisporites seebergensis (72.). R 1888 1s3. See also Pl. 12 fig. 7. 

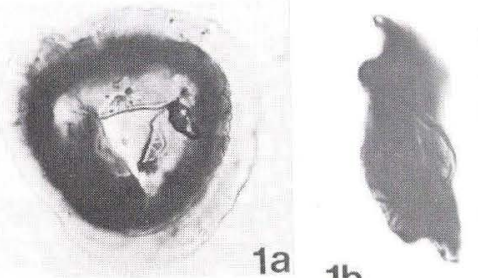

$1 b$

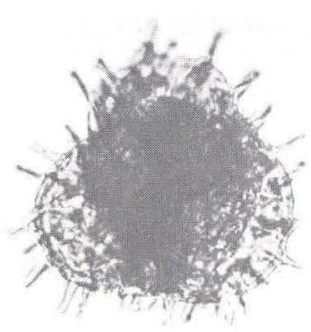

4

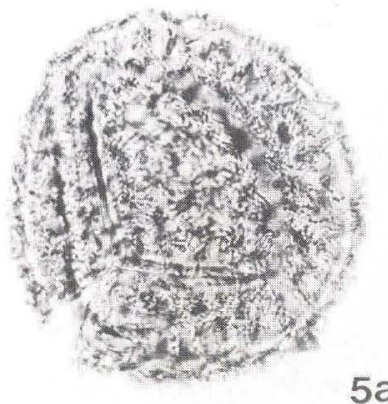

$5 a$

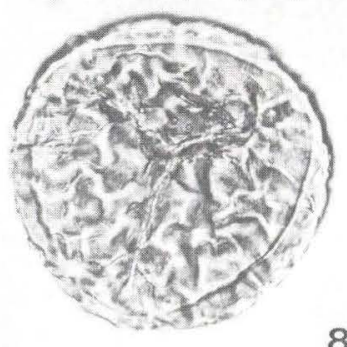

8

$7 a$
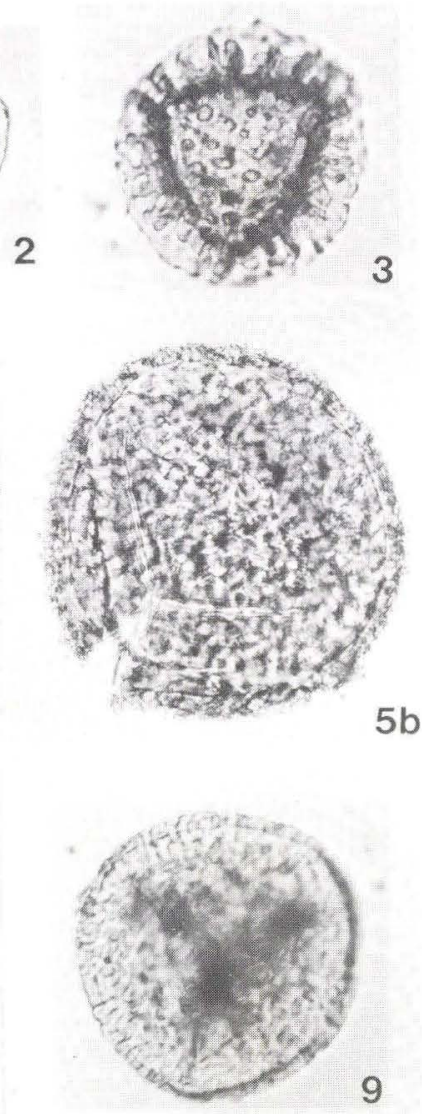

9

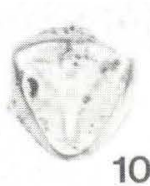

10

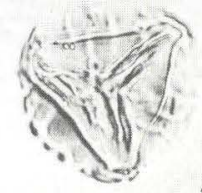

11
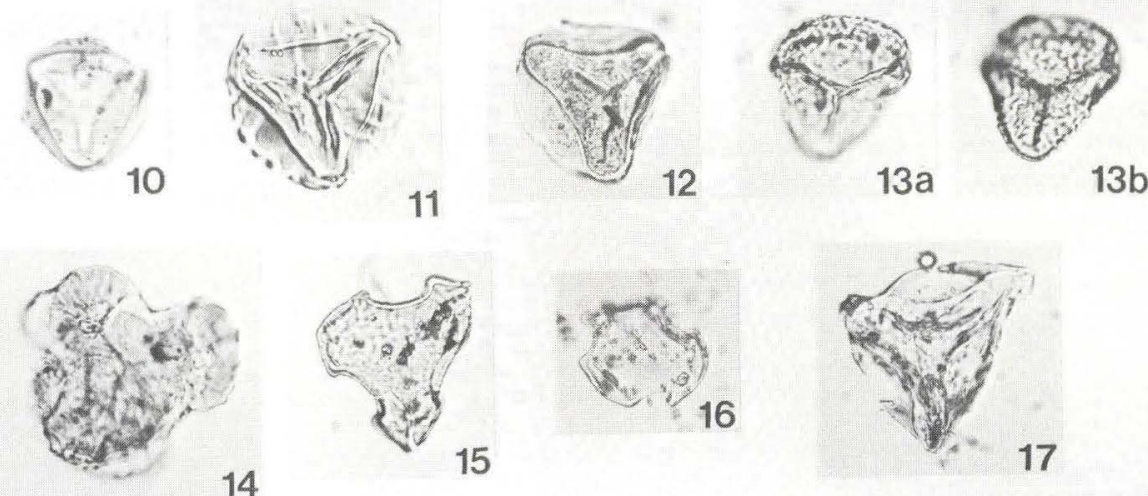

16

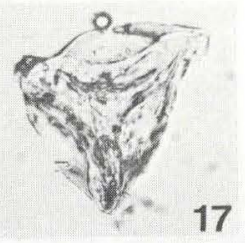




\section{Plate 6}

Fig. 1: Laevigatosporites mesozoicus (73.). R $1753 \mathrm{Sg} .6$.

Fig. 2: Marattisporites scabratus (74.). R $1560 \mathrm{Sg} .6$.

Fig. 3: Aratrisporites fimbriatus (75.). R $1842 \mathrm{Sg} .23$.

Figs. 4 \& 5: Aratrisporites minimus (76.). Fig. 4: R 1792 Sg. 4. Fig. 5: R 1561 Sg. 44. (See also Pl. 12 fig. 4).

Figs. 6a-b: Chasmatosporites hians (77.). R $1560 \mathrm{Sg} .14$.

Figs. 7a-b \& 8: Chasmatosporites elegans (78.). Fig. 7a-b: R 1753 Sg. 2. Fig. 8: R 1843 Sg. 7.

Fig. 9: Chasmatosporites apertus (79.). R $1839 \mathrm{Sg} .23$.

Fig. 10: Monosulcites minimus (80.). R $18591 \mathrm{~s} 8$.

Fig. 11: Monosulcites punctatus (81.). R $2163 \mathrm{Sg} .7$.

Fig. 12: Monosulcites cf. punctatus (82.). R $2163 \mathrm{Sg} .8$.

Figs. 13a-b: Ricciisporites tuberculatus (87.). R 1981 SEM-slide A, fig. 13a scanning micrograph $\times 500$, (Note difference in size due to swelling).

Figs. 14a-b: Clavatipollenites hughesi (86.). R $1721 \mathrm{Sg} .77$.

Fig. 15: Eucommiidites troedsoni (88.). R $1560 \mathrm{Sg} .13$.

Fig. 16: Eucommiidites major (89.). R $2326 \mathrm{Sg} .15$. 

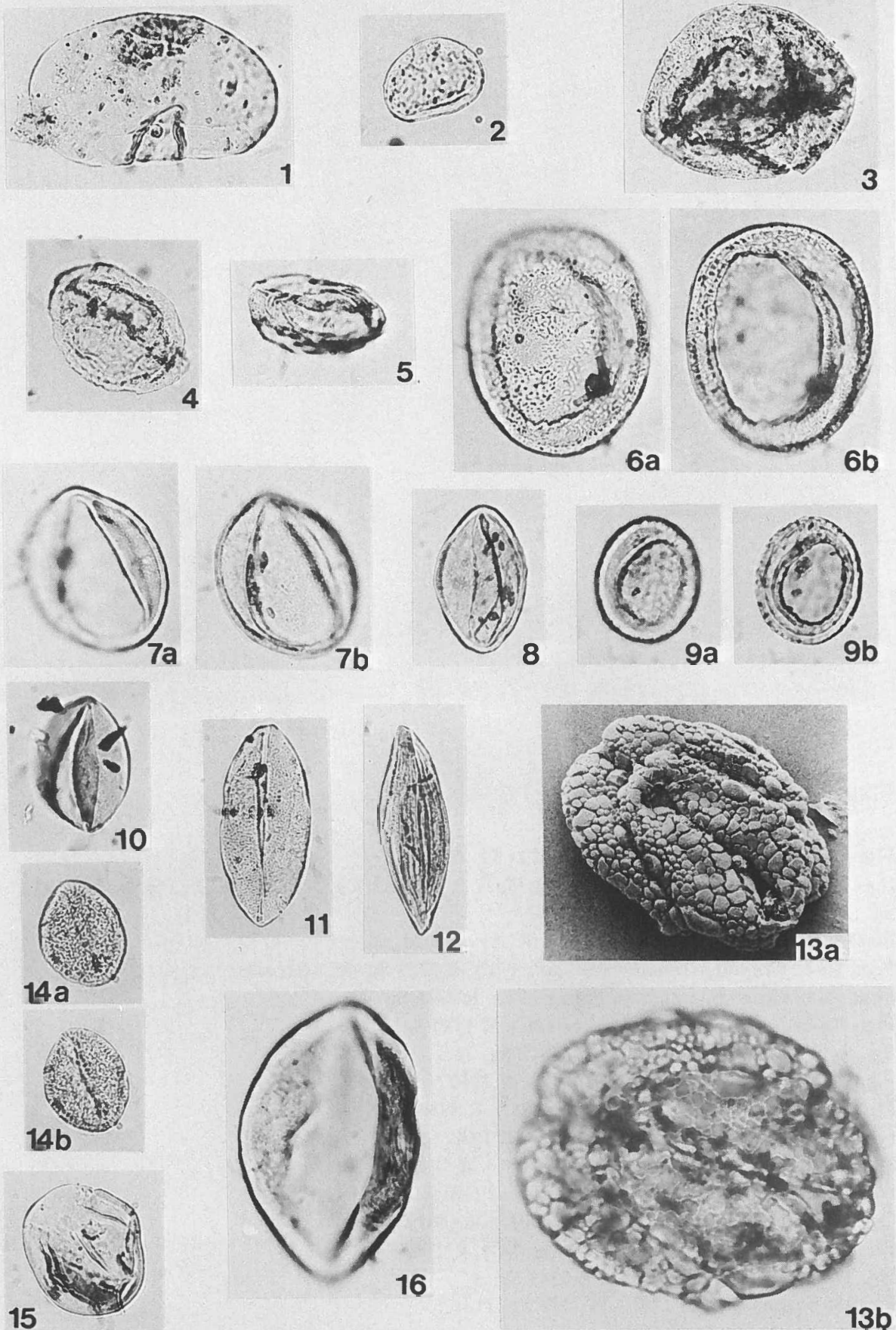

8 D.G.U. II. rk. nr. 109 


\section{Plate 7}

Fig. 1: Ephedripites torosus (90.). R $1721 \mathrm{Sg} .6$.

Figs. 2, 3\& 4a-b: Corollina torosus (91.). Fig. 2: R 1721 1s2. Fig. 3: R 1930 Sg. 25. Fig. 4a-b: R 1930 Sg. 24.

Figs. 5a-b: Corollina zwolinskai (92.). R 1930 Sg. 20.

Figs. 6a-b: Granuloperculatipollis rudis (93.). R $2326 \mathrm{Sg}$. 35, (tetraed).

Figs. 7a-b: Granuloperculatipollis sp. (94.). R 2326 Sg. 41.

Figs. 8a-b: Rhaetipollis germanicus (95.). R 1930 Sg. 3.

Fig. 9: Cf. Rhaetipollis sp. (96.). R $1842 \mathrm{Sg} .14$.

Fig. 10: Perinopollenites elatoides (97.). R 1930 Sg. 29.

Fig. 11: Perinopollenites cf. elatoides (98.). R 1859 1s5.

Fig. 12: Araucariacidites australis (99.). R 1930 Sg. 32.

Fig. 13: Araucariacidites cf. australis (100.). R 1843 Sg. 52.

Fig. 14: Cerebropollenites macroverrucosus (101.). R $1561 \mathrm{Gg}$. A.

Fig. 15: Cerebropollenites thiergartii (102.). R $1561 \mathrm{Gg}$. A.

Figs. 16a-b: Echinitosporites iliacoides (84.). R 2345 Sg. 7.

Fig. 17: Gen. et sp. indet. (85.). R $2345 \mathrm{Sg} .8$.

Fig. 18: Enzonasporites (103.). R 2326 Sg. 31. 

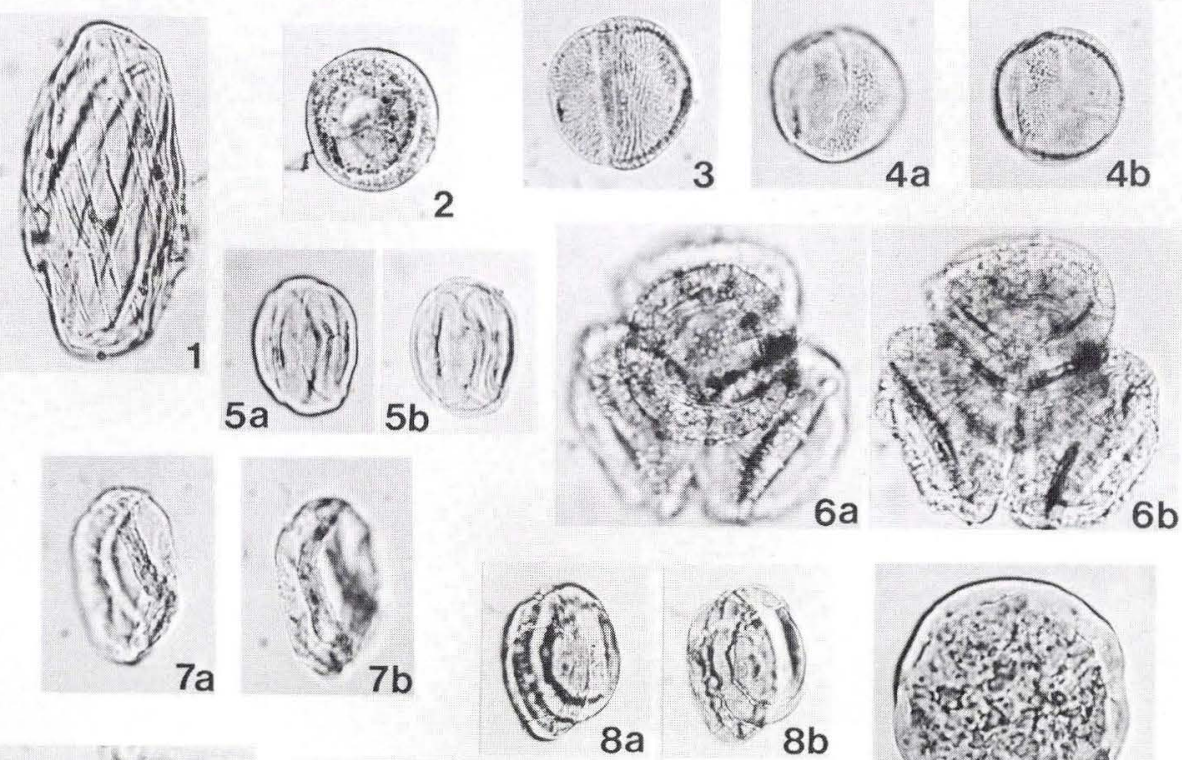
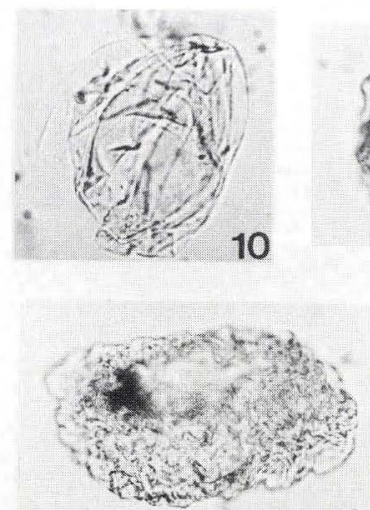

14
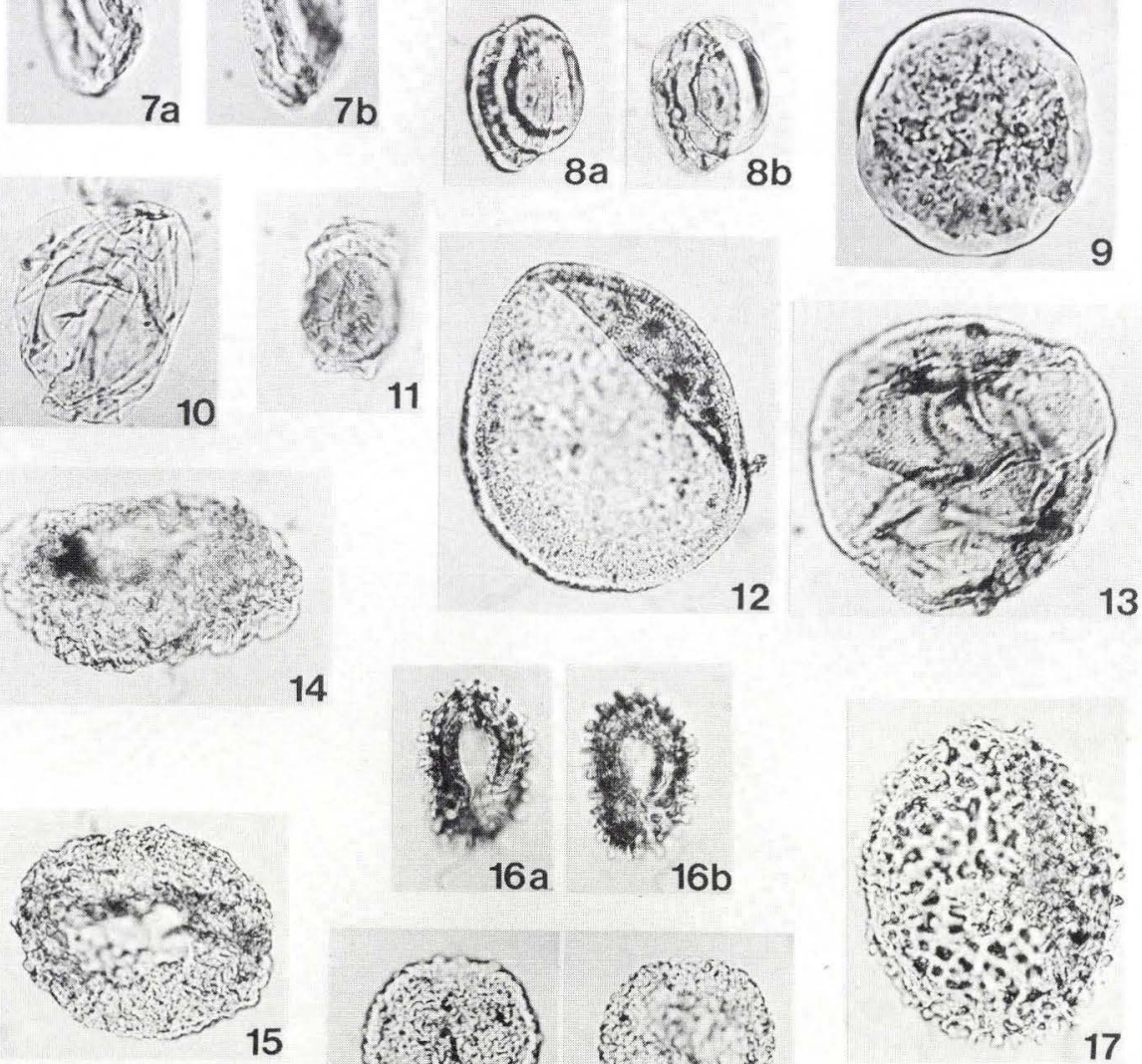

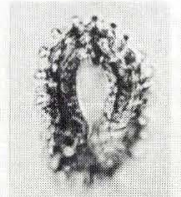

$16 a$

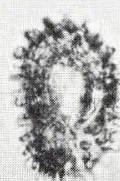

$16 b$
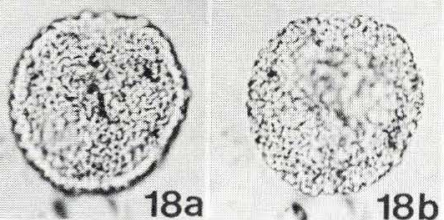

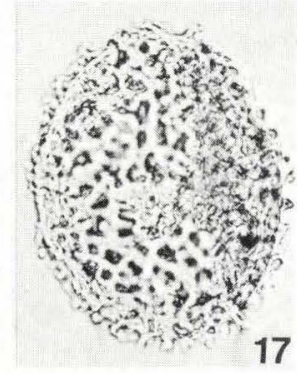


Plate 8

Fig. 1: Ovalipollis ovalis (104.). R $1930 \mathrm{Sg} .31$.

Fig. 2: Ovalipollis breviformis (105.). R $2326 \mathrm{Sg}$. 28.

Fig. 3: Ovalipollis notabilis (106.). R $2345 \mathrm{Gg}$. A.

Fig. 4: Taeniaesporites rhaeticus (107.). R $2326 \mathrm{Sg} .26$.

Fig. 5: Protohaploxypinus hercynicus (108.). R 1930 Sg. 44. (Fissured under mounting.)

Figs. 6a-b: Infernopollenites sp. (109.). R $1930 \mathrm{Sg}$. 50.

Figs. 7 \& 8: Quadraeculina anellaeformis (110.). Both specimens: R $1560 \mathrm{Gg}$. B.

Fig. 9: Vitreisporites pallidus (112.). R $2326 \mathrm{Sg} .20$.

Fig. 10: Protopinus scanicus (111.). R $1981 \mathrm{Sg} .17$.

Fig. 11: Vitreisporites bjuvensis (113.). R $1930 \mathrm{Sg} .52$.

Fig. 12: Alisporites diaphanus (114.). R $2326 \mathrm{Sg} .22$. 

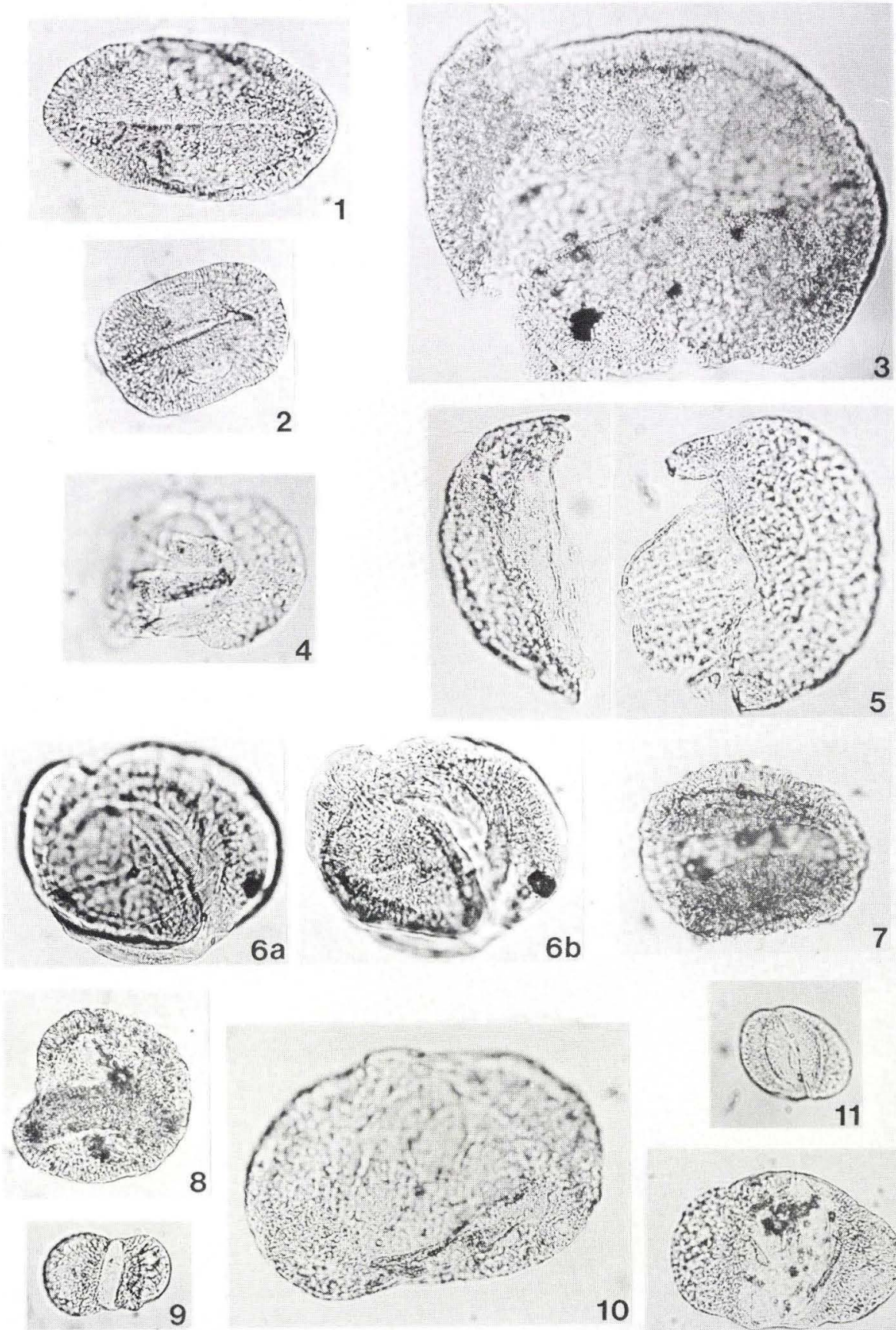

11

10

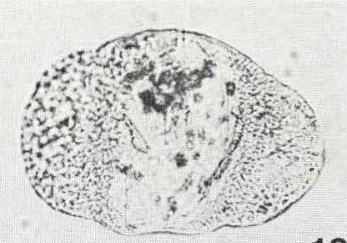




\section{Plate 9}

Figs. 1 \& 2: Alisporites robustus (115.). Fig. 1: R 1981 Sg. 11. Fig. 2: R 1842 Sg. 56. Figs. 3 \& 4: Alisporites radialis (116.). Fig. 3: R 1842 Sg. 17. Fig. 4: R $1560 \mathrm{Gg}$. C.

Figs. 5 \& 6a-b: Pinuspollenites minimus (117.). Fig. 5: R 2163 Sg. 12. Fig. 6a-b: R 1839 Sg. 38. Fig. 7: Pinuspollenites pinoides (118.). R 1827 1s7.

Fig. 8: "Pityosporites" neomundanus (119.). R 2345 Sg. 9.

Fig. 9: Polonisaccus ferrugineus (120.). R $1888 \mathrm{Sg} .15$. 

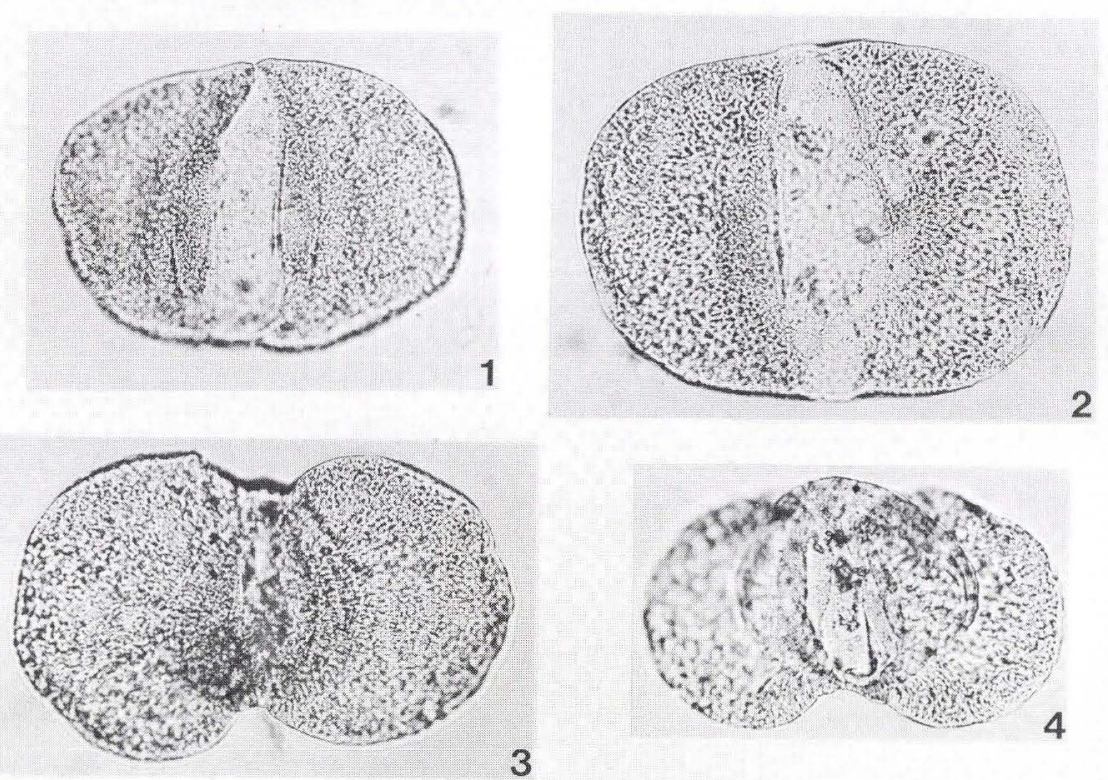

3
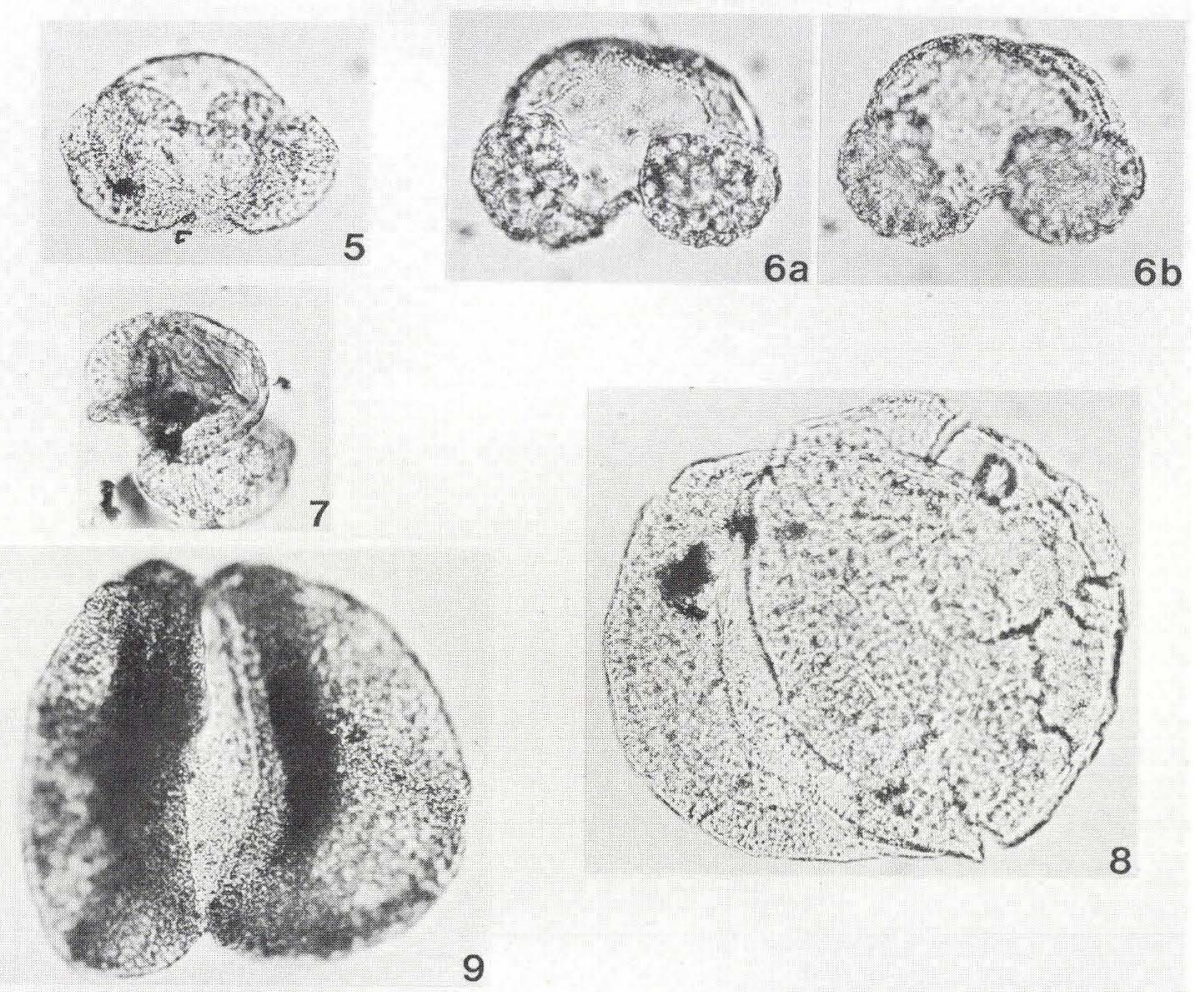
Plate 10

Figs. 1a-b: Chordasporites platysaccus (121.). R $1827 \mathrm{Sg} .6$.

Figs. 2a-b: Schismatosporites ovalis (122.). R $1560 \mathrm{Sg} .15$.

Fig. 3: Schizosaccus keuperi (123.). R 2326 Sg. 26.

Fig. 4: Botryococcus sp. (126.). R 19816 s4.

Figs. 5a-b: "Vesicaspora" fuscus (124.). R 1930 Sg. 43.

Fig. 6: Cf. Schizosporis sp. (127.). R 1859 Sg. 16.

Fig. 7: Schizocystia cf. rara (128.). R $1862 \mathrm{Sg}$. 1. (See also Pl. 12 fig. 5.)

Figs. 8a-b: Crassosphaera sp. (129.). R 1827 Sg. 4. 

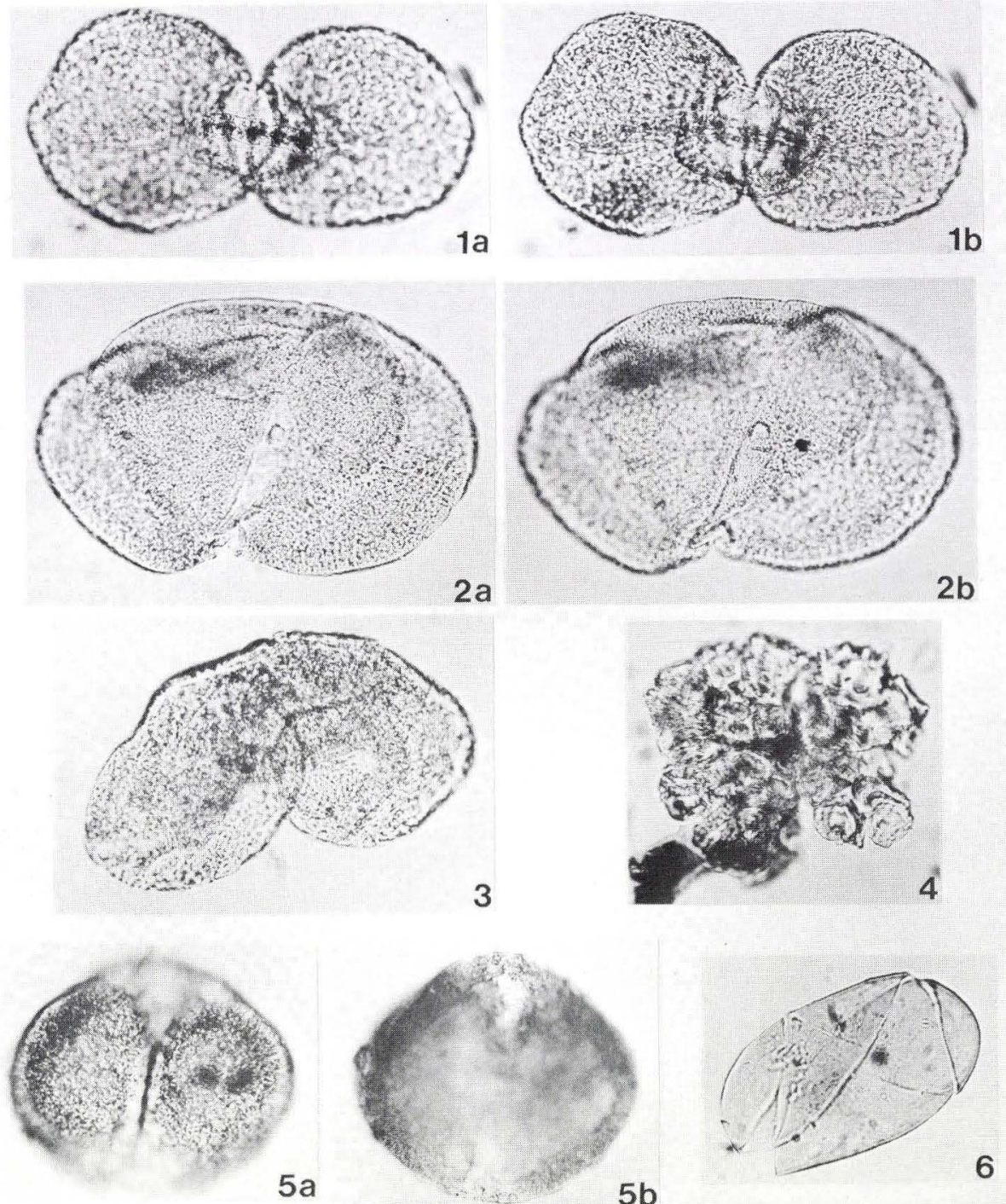

$5 b$
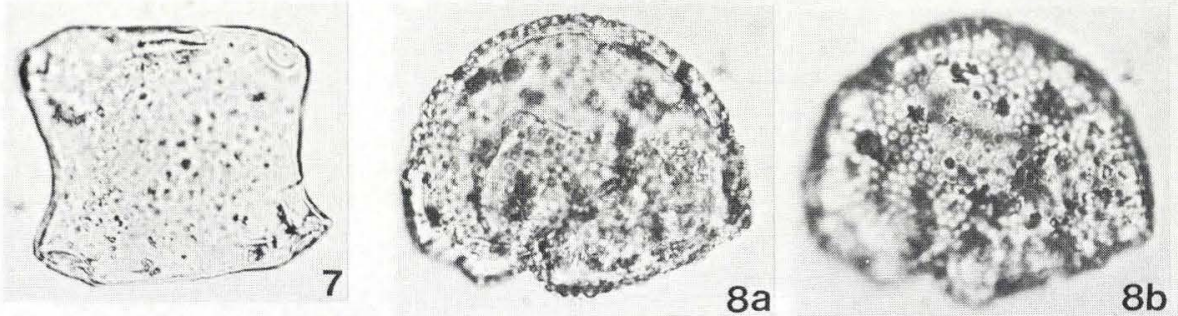


\section{Plate 11. All specimens $\times 1000$}

Fig. 1: Micrhystridium lymensis (132.). R $19302 \mathrm{~s} 1$.

Fig. 2: Micrhystridium fragile (133.). R $1721 \mathrm{Sg} .4$.

Fig. 3: Micrhystridium ef. karamurzae (135.). R $1721 \mathrm{Sg} .3$.

Fig. 4: Micrhystridium cf. wattonensis (136.). R 19305 s4.

Figs. 5 \& 6: Micrhystridium minutispinosum (137.). Both specimens: R $19305 \mathrm{~s} 4$.

Fig. 7: Leiofusa jurassica (138.). R $18395 \mathrm{~s} 1$.

Fig. 8: Wilsonastrum colonicum (139.). R $1560 \mathrm{Sg} .3$.

Fig. 9: Domasia liassica (140.) R 1721 Sg. 5.

Fig. 10: Metaleiofusa sp. (141.). R 1930 Sg. 48.

Fig. 11. Veryhachium sp. 1 (142.). R $1930 \mathrm{Sg} .2$.

Figs. 12a-b: Cf. Dapcodium sp. (144.). R 1930 5s4.

Rig. 13: Gen. et sp. indet (145.). R $1560 \mathrm{Sg} .2$. 
D.G.U. II. Rk. Nr. 109
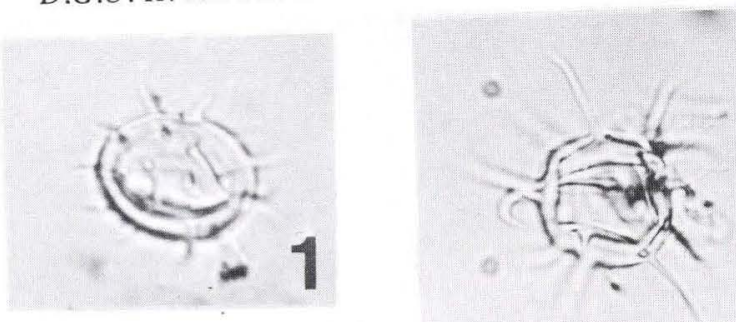

2

3
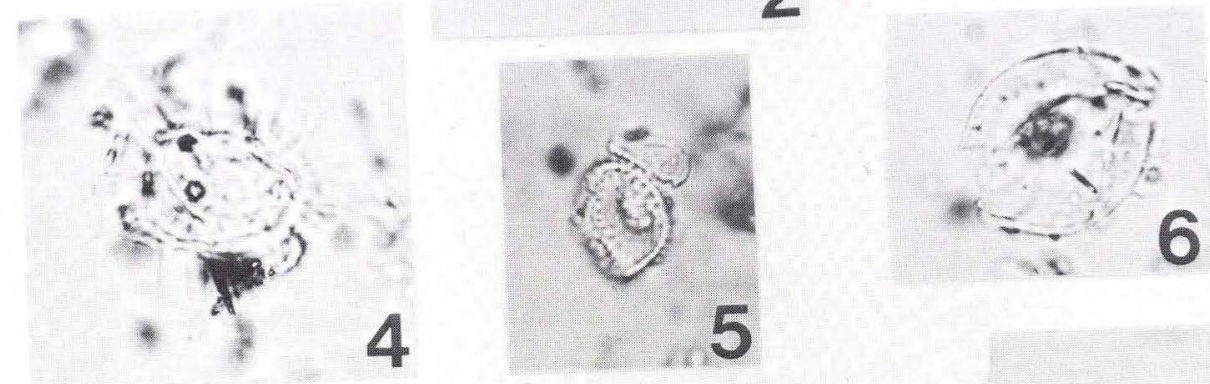

$4 \quad 5$
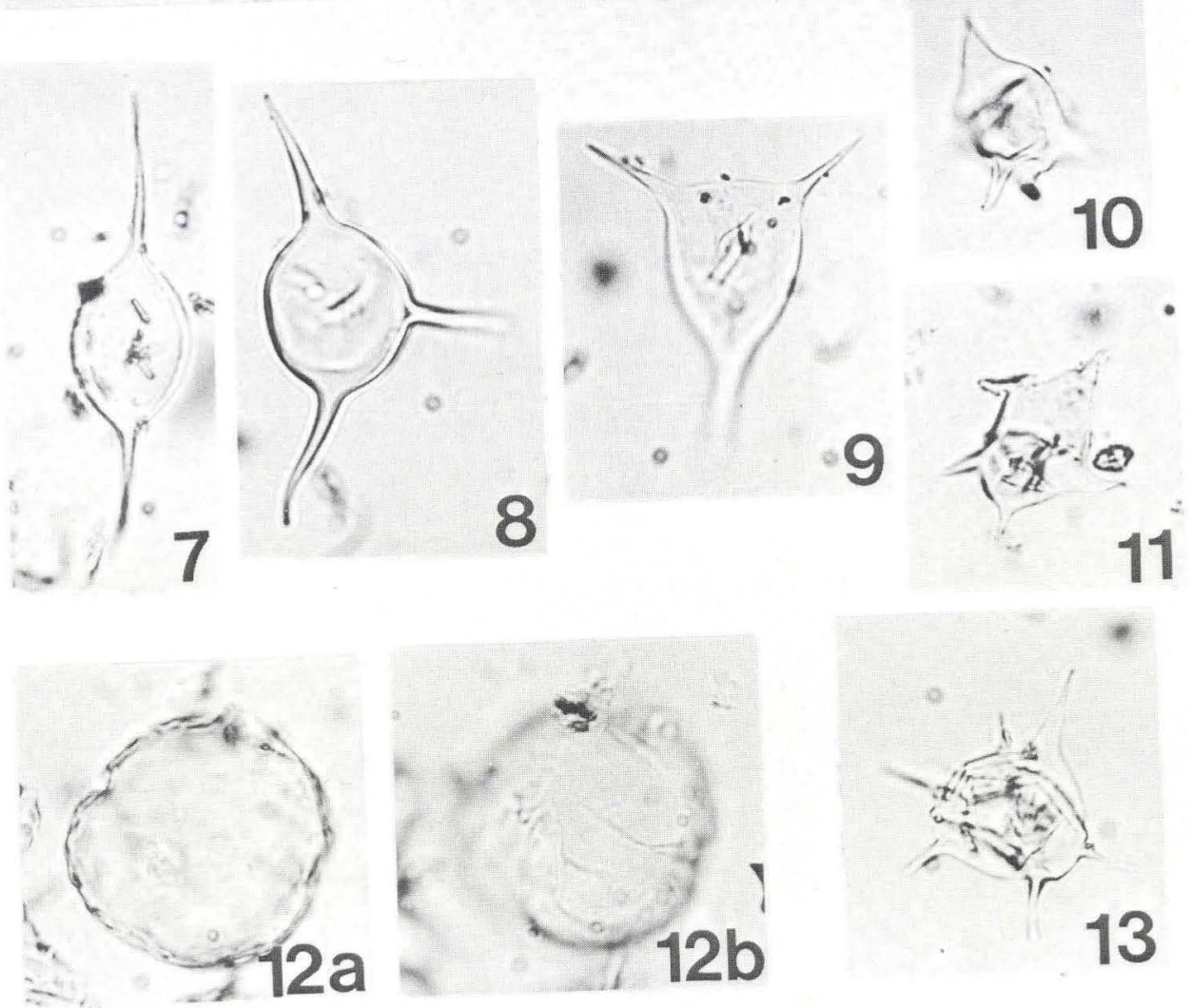


\section{Plate 12}

NB specimens from several localities

\section{Rødby 1:}

Fig. 1: Tasmanitas sp. (131.). R $1960 \mathrm{Sg} .16$.

Figs. 2a-b: Cymatiosphaera sp. (130.). R 1930 Pg. B.

Munkerup Clay, Bornholm (mounted in glycerine):

Fig. 3: Nevesisporites limbatus (18.). M6 2g8.

Figs. 4a-b: Aratrisporites minimus (76.). M10 2g4.

Fig. 5: Schizocystia cf. rara (128.). MKb $1 \mathrm{~g} 1$.

Eitzendorf 8 (mounted in glycerine):

Figs. 6a-b: Naiditaspora harrisi Orb. E8 $1203 \mathrm{~m} 2 \mathrm{~g} 2$.

Fig. 7: Cornutisporites seebergensis (72.). E8 $1103 \mathrm{~m} 1 \mathrm{~g} 1$.

Scania (mounted in glycerinegelatine):

Figs. 8a-b: Deltoidospora crassexina Nilsson (4.). Sandåkra. Holotype = Pl. 1, fig. 11 in Nilsson 1958. (Note thickened "semidistal" ridges at fig. 8b.)

Figs. 9a-b: Trachysporites fuscus Nilsson (20.). Höör. Holotype = Pl. 2, fig. 1 in Nilsson 1958. Figs. 10a-b: Chasmatosporites elegans Nilsson (78.). Holotype = Pl. 4, fig. 12 in Nilsson 1958. 

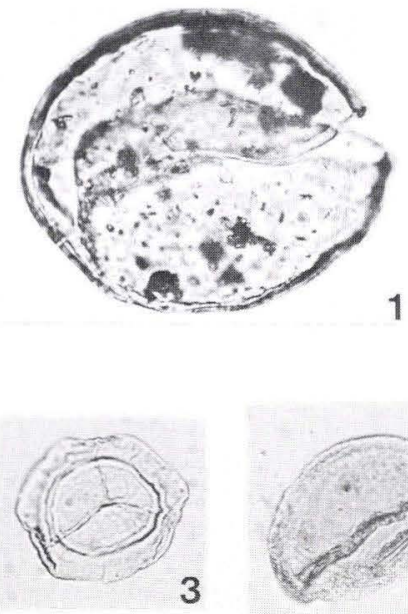

3
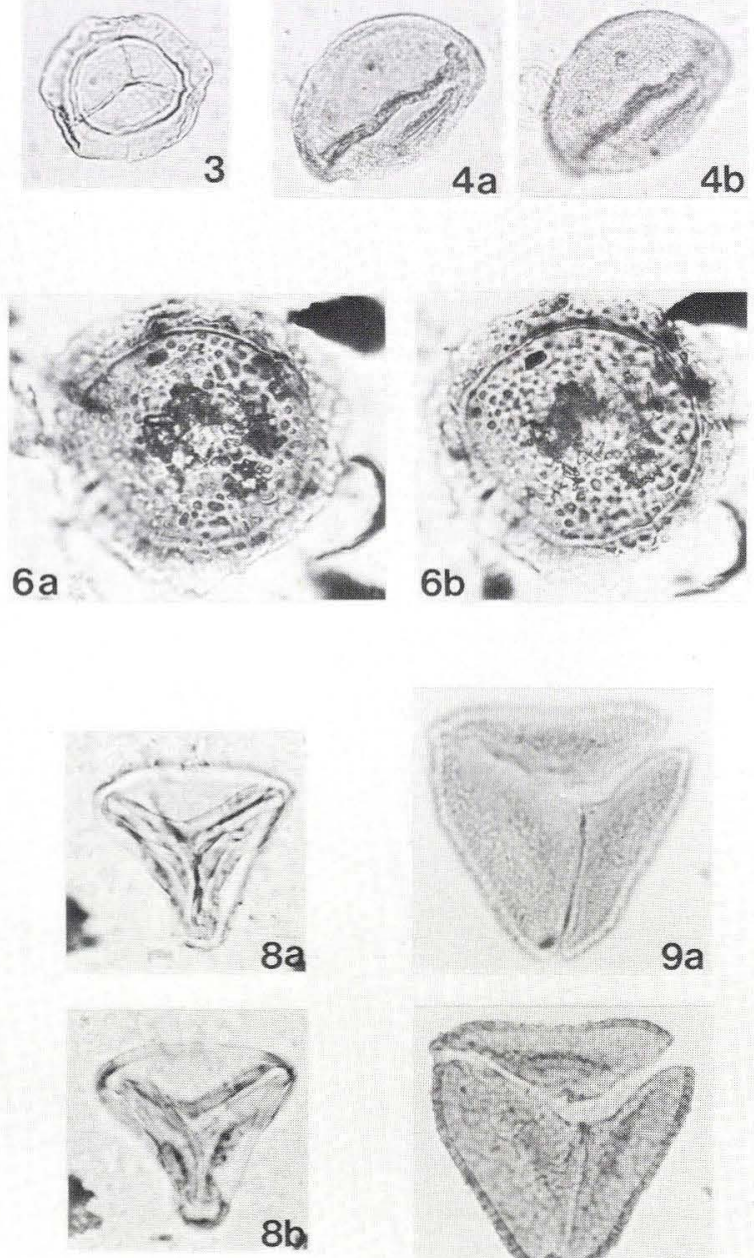
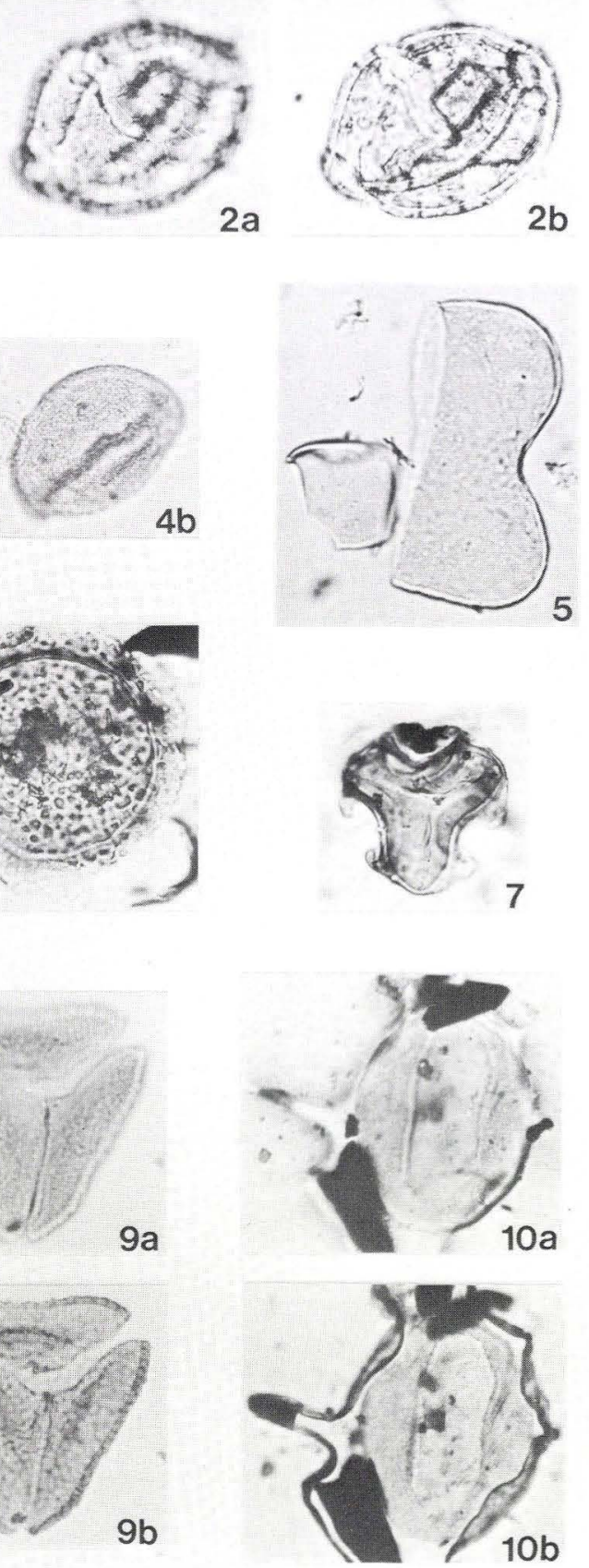
